Assessing the Effectiveness of the Volunteer Farmer Trainer Approach in Dissemination of Livestock Feed Technologies in Kenya vis-à-vis Other Information Sources

Mercy Mwambi, Evelyne Kiptot and Steven Franzel

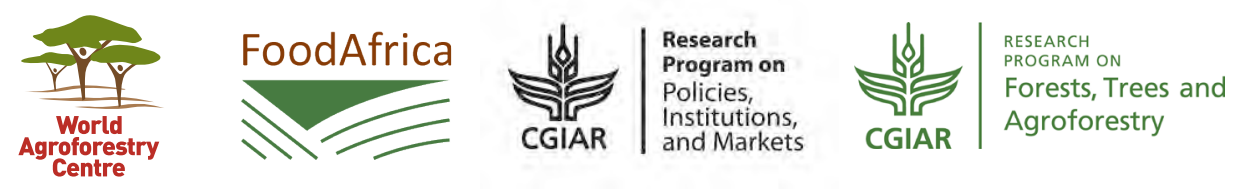

INTERNAIONAL 
Assessing the Effectiveness of the Volunteer Farmer Trainer Approach in Dissemination of Livestock Feed Technologies in Kenya vis-à-vis Other Information Sources

Mercy Mwambi, Evelyne Kiptot and Steven Franzel
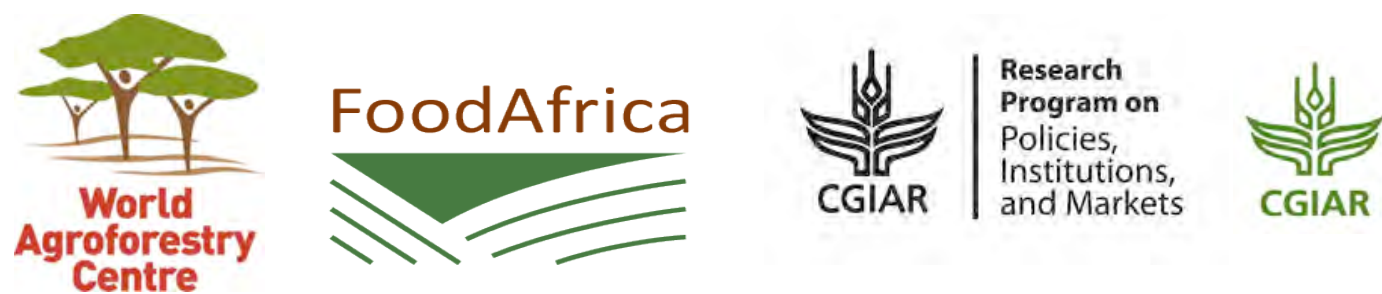
Correct citation: Mwambi M, Kiptot E, Franzel S. 2015. Assessing the Effectiveness of the Volunteer Farmer Trainer Approach in Dissemination of Livestock Feed Technologies in Kenya vis-à-vis other Information Sources. ICRAF Working Paper No. 199. Nairobi, World Agroforestry Centre. DOI: http://dx.doi.org/10.5716/WP15022.PDF

Titles in the Working Paper Series aim to disseminate interim results on agroforestry research and practices and stimulate feedback from the scientific community. Other publication series from the World Agroforestry Centre include: Technical Manuals, Occasional Papers and the Trees for Change Series.

Published by the World Agroforestry Centre

United Nations Avenue

PO Box 30677, GPO 00100

Nairobi, Kenya

Tel: +254(0)20 722 4000, via USA +1 6508336645

Fax: +254(0)20 722 4001, via USA +1 6508336646

Email: worldagroforestry@cgiar.org

Website: www.worldagroforestry.org

(C) World Agroforestry Centre

Working Paper No. 199

The views expressed in this publication are those of the authors and not necessarily those of the World Agroforestry Centre.

Articles appearing in the Working Paper Series may be quoted or reproduced without charge, provided their source is acknowledged. 


\section{THE AUTHORS}

Mercy Mwambi works for the World Agroforestry Centre, Nairobi, Kenya.

Evelyn Kiptot works for the World Agroforestry Centre, Nairobi, Kenya.

Steven Franzel works for the World Agroforestry Centre, based in the USA.

\section{ACKNOWLEDGEMENTS}

The authors are grateful to the Food Africa Programme financed by the Ministry of Foreign Affairs, Finland for providing financial support. We are grateful for the support of the EADD Project and two CGIAR research programmes: Policies, Institutions and Markets; and Forests, Trees and Agroforestry. This work was undertaken as part of the CGIAR Research Programme on Policies, Institutions, and Markets (PIM) led by the International Food Policy Research Institute (IFPRI). This publication has not gone through IFPRI's standard peerreview procedure. The opinions expressed here belong to the authors, and do not necessarily reflect those of PIM, IFPRI, ICRAF or the CGIAR. We extend our appreciation to the enumerators who participated in this survey and Constant Kokonya for data entry. We thank all the farmers who participated in this survey. 


\section{TABLE OF CONTENTS}

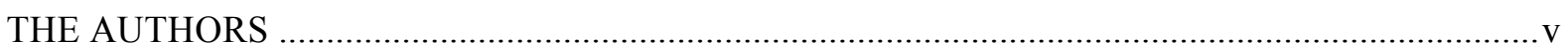

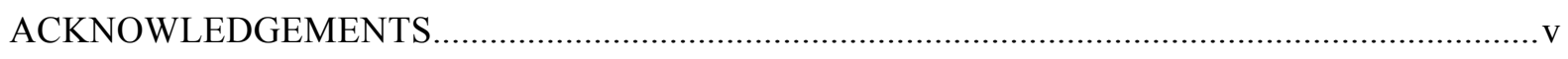

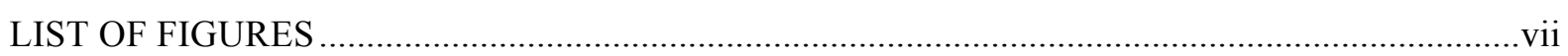

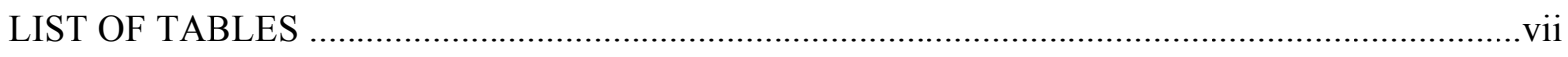

LIST OF ABBREVIATIONS \& ACRONYMS .........................................................................

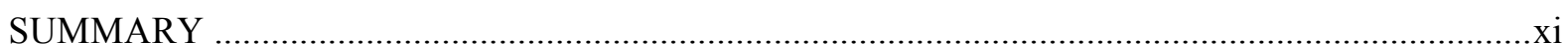

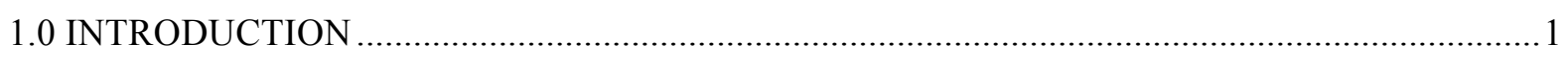

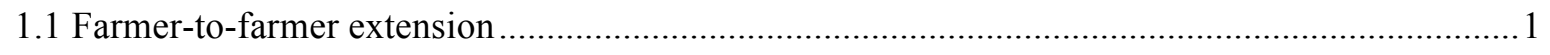

1.2 An overview of East Africa Dairy Development Project .............................................................2

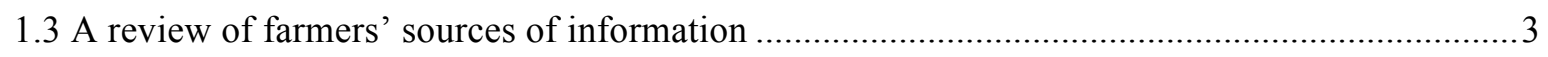

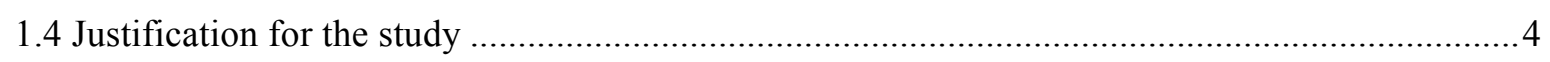

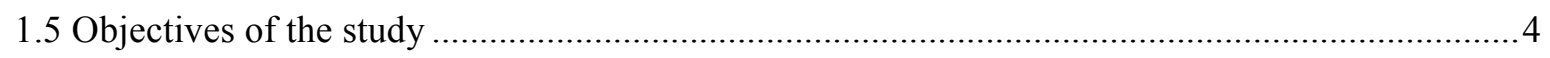

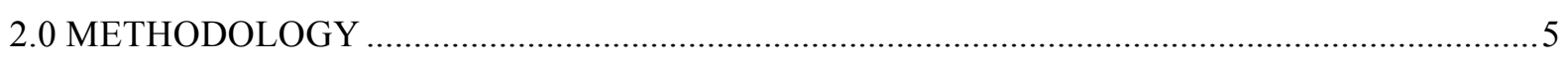

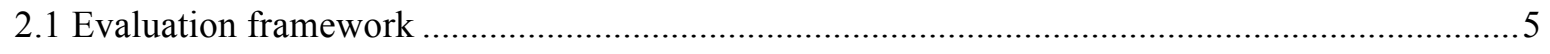

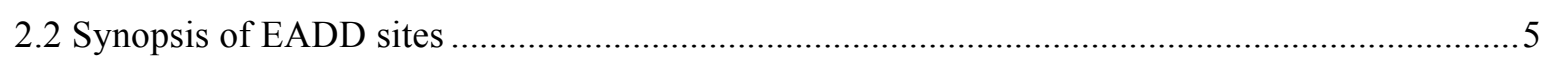

2.3 Study area

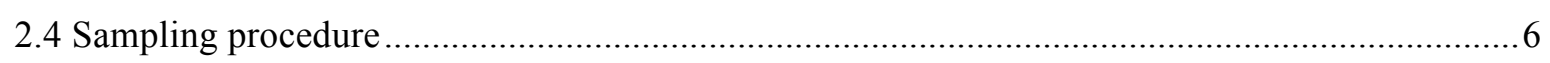

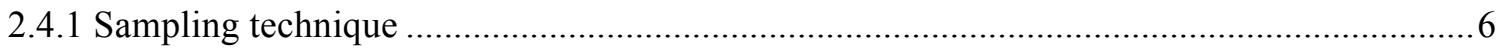

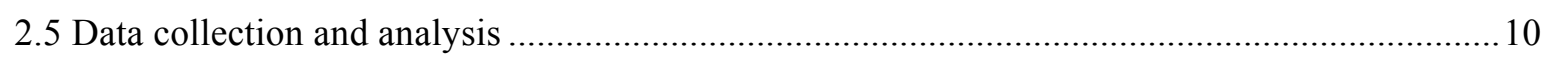

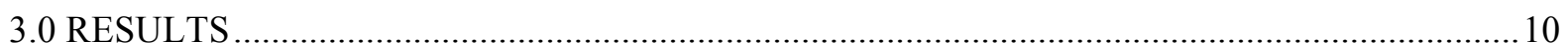

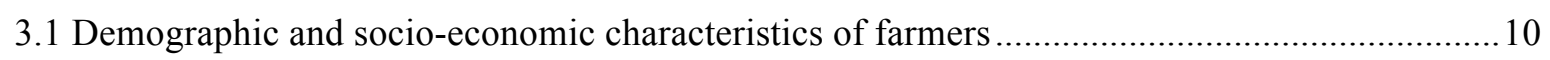

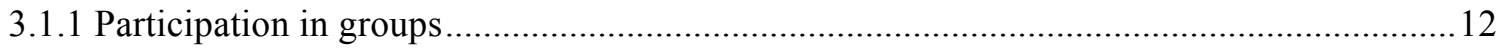

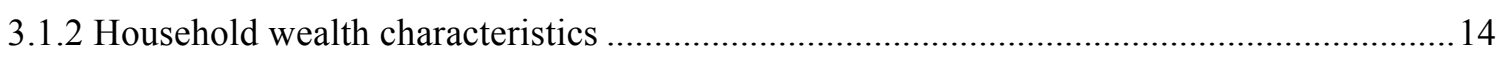

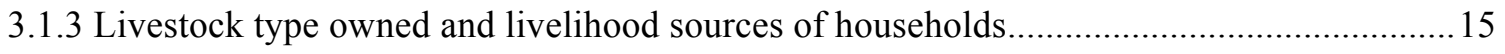

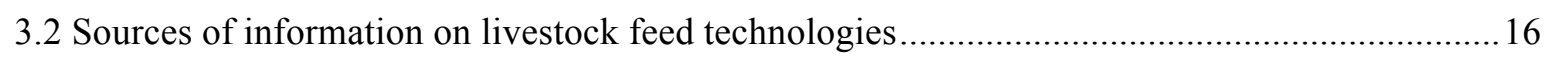

3.3 Types of livestock feed technologies accessed from various information sources .....................21

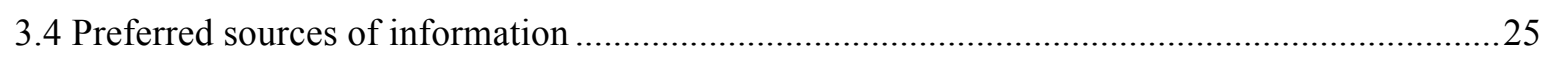

3.4.1 Frequency of use, reliability, accessibility and affordability of preferred sources of

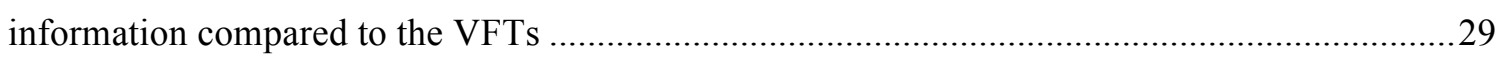

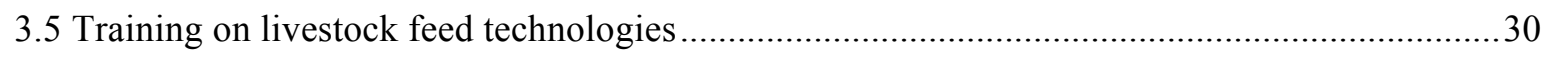

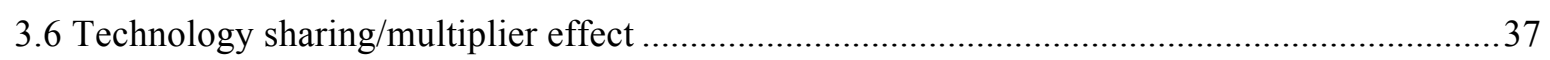

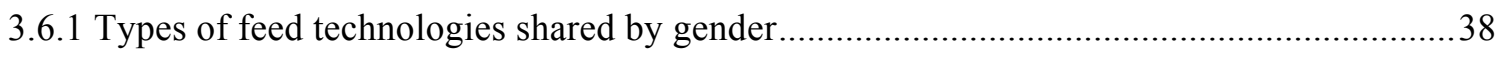

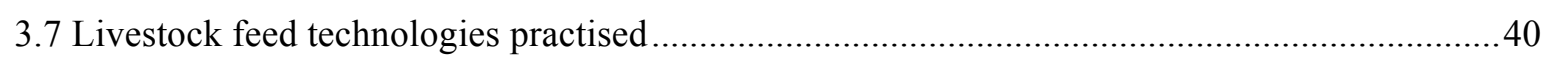

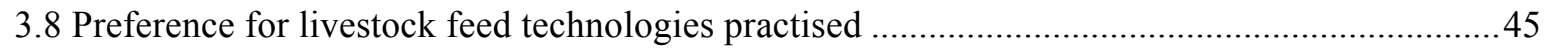

3.9 Test on level of understanding of livestock feed technologies................................................. 49

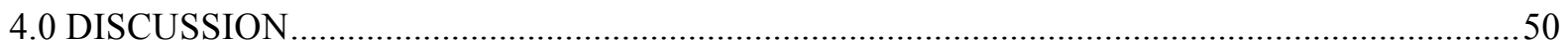




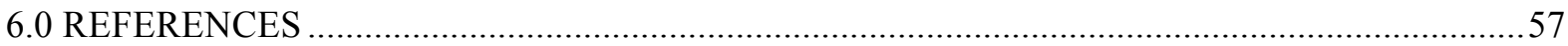

\section{LIST OF FIGURES}

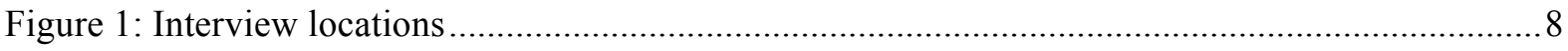

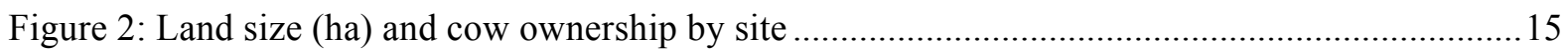

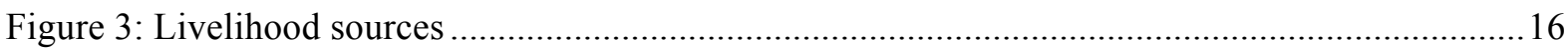

\section{LIST OF TABLES}

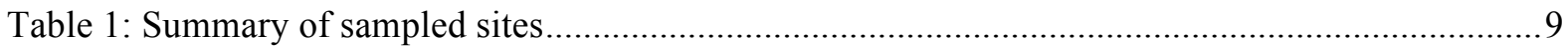

Table 2: Socio-economic characteristics of individual farmers interviewed ........................................11

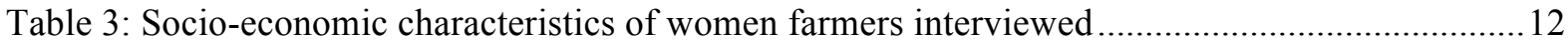

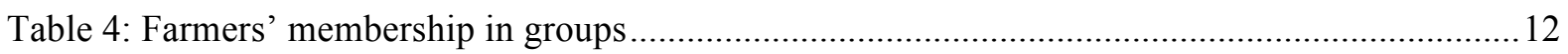

Table 5: Percentage of female farmers participating in groups.......................................................... 13

Table 6: Percentage of farmers belonging to groups concerned with specific agricultural enterprises 13

Table 7: Benefits derived by farmers from participating in agricultural groups ................................... 14

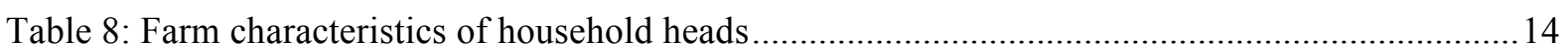

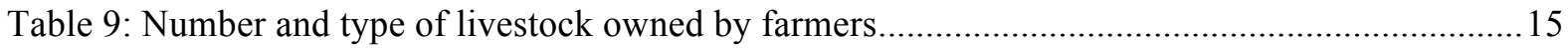

Table 10: Percentage of farmers accessing information from different sources by gender ...................17

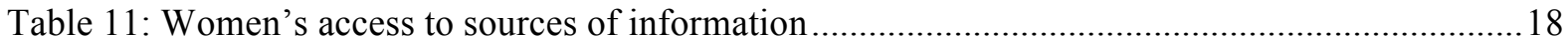

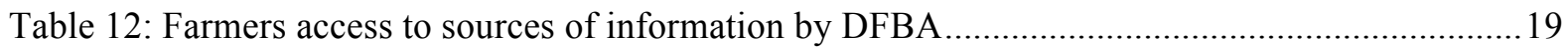

Table 13: Percentage of farmers accessing information from VFTs and percentage of VFTs per site. 20

Table 14: Types of livestock feed technologies accessed from all sources by gender...........................21

Table 15: Types of livestock feed technologies accessed from all sources by women..........................22

Table 16: Farmers' access to livestock feed technologies from different sources .................................24

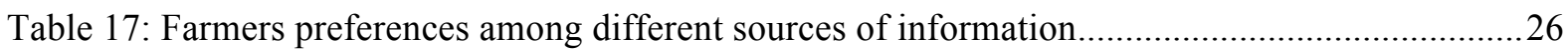

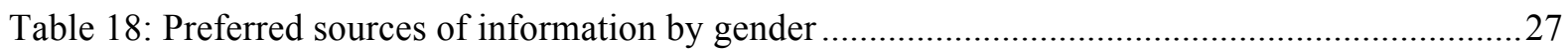

Table 19: Farmers ranking on preferred sources of information by site ............................................28

Table 20: Mean scores on reliability, frequency, accessibility and affordability of preferred sources of

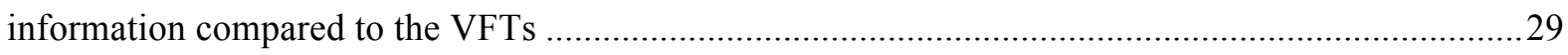

Table 21: Reliability, frequency, accessibility and affordability of preferred sources of information

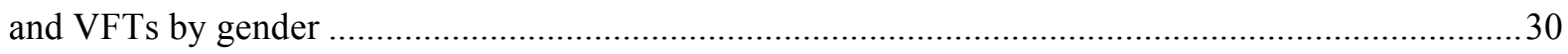

Table 22: Household members who have ever received training from any source...............................30

Table 23: Training on livestock feed technologies by gender ........................................................... 31

Table 24: Disparities in training on livestock feed technologies between women in male-headed

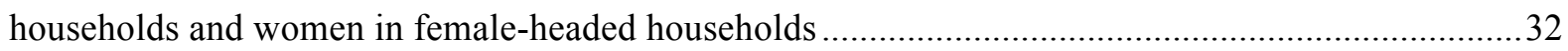

Table 25: Percentage of farmers trained on livestock feed technologies by site....................................34

Table 26: Percentage of farmers trained on livestock feed technologies by institution ...........................35 
Table 27: Percentage of farmers reporting on frequency of training by institutions in the past six months .36

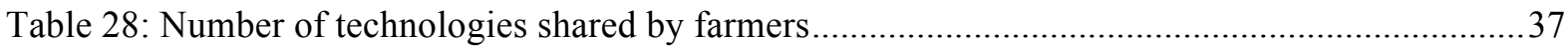

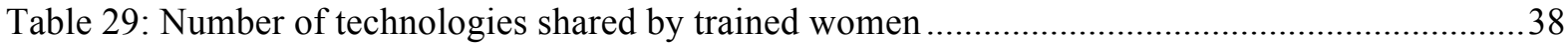

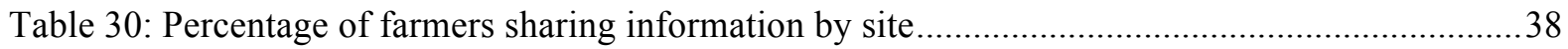

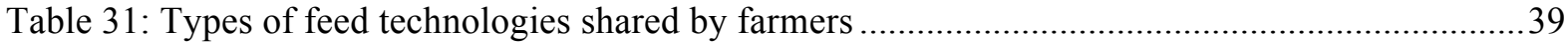

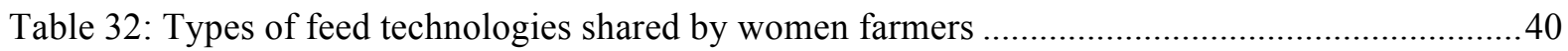

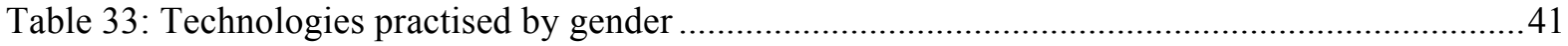

Table 34: Technologies practised by female heads and women in male-headed households ...............42

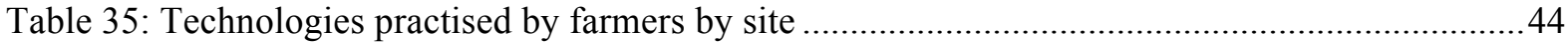

Table 36: Ranking of farmers' preference for livestock feed technologies practised by gender ..........46

Table 37: Ranking of farmers' preferred livestock feed technologies practised by site .......................47

Table 38: Percentage of farmers trained, practising and sharing information on selected feed technologies 48

Table 39: Farmers' mean score on understanding of livestock feed technologies 


\section{LIST OF ABBREVIATIONS \& ACRONYMS}

\begin{tabular}{|c|c|}
\hline ABSTCM & African Breeding Services Total Cattle Management \\
\hline AEZ & Agroecological Zone \\
\hline AI & Artificial Insemination \\
\hline ASK & Agricultural Society of Kenya \\
\hline CESP & Community Extension Service Provider \\
\hline CGIAR & Consultative Group for International Agricultural Research \\
\hline DFBA & Dairy Farmers' Business Association \\
\hline DMG & Dairy Management Group \\
\hline EADD & East Africa Dairy Development \\
\hline EV & Exchange Visit \\
\hline FAO & Food and Agricultural Organization of the United Nations \\
\hline FD & Field Day \\
\hline FFE & Farmer-to-Farmer Extension \\
\hline FO & Farmer Organization \\
\hline ICRAF & World Agroforestry Centre \\
\hline ICT & Information and Communication Technology \\
\hline ID & Input Dealers \\
\hline IFPRI & International Food Policy Research Institute \\
\hline KARI & Kenya Agricultural Research Institute \\
\hline LH & Lower Highland \\
\hline LM & Lower Midland \\
\hline MICCA & Mitigation of Climate Change in Agriculture \\
\hline MoALFD & Ministry of Agriculture, Livestock and Fisheries Development \\
\hline MP & Mobile Phone \\
\hline NGO & Non-governmental Organization \\
\hline PIM & Policies, Institutions and Markets \\
\hline
\end{tabular}


PSP Private Service Provider

SF Skilled Farmer

SRI System of Rice Intensification

TV Television

UH Upper Highland

UM Upper Midland

VFT Volunteer Farmer Trainer 


\section{SUMMARY}

Improvement in agricultural production, productivity and sustainability is dependent on farmers' access to up-to-date information on modern agricultural technologies. In the past, agricultural extension officers played an important role in disseminating knowledge from researchers to farmers. However, this linear model of extension was not effective. As a result, the extension system in developing countries has been changing to accommodate challenges presented by the linear model. Major modifications include the introduction of participatory approaches and the proliferation of many sources providing agricultural information. The sources could be interpersonal or impersonal. Farmers' choice of a particular source can be determined by various factors including socio-economic characteristics of the farmer, reliability, accessibility and affordability of the information source. Previous studies have been done to determine farmers' preferences for sources of information. However, little has been done to establish the type of information accessed from particular information sources. This study addresses the gap by assessing the effectiveness of the Volunteer Farmer Trainer (VFT) approach in disseminating information vis-a-vis other sources of knowledge. The VFT approach is a type of farmer-to-farmer extension model that is used by the East Africa Dairy Development (EADD) project in Kenya to disseminate information on livestock feed innovations. The objectives of the study were to identify farmers' sources of information, information source preference, access to and training on livestock feed technologies and technology sharing among farmers.

The findings indicate that radio was the most accessed source of information followed by Community Extension Service Providers (CESPs), neighbours, field days and the Ministry of Agriculture, Livestock and Fisheries Development (MoALFD); all accessed by more than $40 \%$ of the sampled farmers. With regard to gender, a significantly higher percentage of male farmers than female farmers had access to most of the information sources. Examples include radio, field days, agricultural shows, skilled farmers, written materials, demonstrations, newspapers, breeders' shows, mobile phones and posters. Clearly, male farmers have more access to both electronic and interpersonal sources of information than their female counterparts.

Results by household type show that a greater proportion of women-headed households had access to MoALFD and private service providers than women in male-headed households. Further, the findings reveal that VFTs were among the top five most accessed sources of information by women-headed households but was ranked $8^{\text {th }}$ among women in male-headed households. The $5^{\text {th }}$ rank obtained by the VFTs implies that farmer trainers were among the major accessed information sources by women-headed household perhaps because of their proximity, implying that less cost is needed to access them. The rank of VFTs varied across sites. Implications are that some farmers do not appreciate the VFTs which could be because they feel that fellow farmers might not have adequate skills and knowledge to educate them compared to other professional extension agents like the government extension staff. There 
was no correlation between the ratio of farmers per VFT and percentage of farmers accessing information from VFTs per site.

In terms of the feed technologies accessed by farmers, findings indicate that Napier grass, mineral supplementation and concentrates formed the three most accessed feed technologies in that order. A significantly higher proportion of male farmers had access to information on modern feeds, such as Lucerne, desmodium, silage making and fodder shrubs than their female counterparts. Likewise, analysis by women household types shows that a higher percentage of women in male-headed households had access to information on Rhodes grass, conservation of crop residues and feed formulation than their counterparts in women-headed households.

With regard to the type of information accessed from particular sources, information on mineral supplementation, concentrates and Napier grass was mainly accessed from the radio. Other sources like CESPs, field days and MoALFD offered information on Napier grass, Rhodes grass, silage making and conservation of crop residues. For VFTs, their main technologies were Napier grass, Rhodes grass, conservation of crop residues and mineral supplementation. Evidently, farmers access information on common feed technologies from impersonal sources while that on modern technology is accessed from interpersonal sources. Impersonal sources are important in passing general information while interpersonal sources are critical in providing specific information.

The most preferred sources of information of interviewed farmers were CESPs followed by radio and MoALFD, in that order. This means that both interpersonal and impersonal sources are important in information dissemination. With regard to gender however, women had a higher preference for neighbours and thus made good use of their social networks than men who preferred field days. Compared to other information sources, VFTs faired relatively well ranking $7^{\text {th }}$ overall with no major differences between the two genders.

Reliability, frequency of contact, accessibility and affordability of the three most preferred sources were analysed in this study. Further, similar aspects were used to rate how the VFTs fared compared to the three preferred sources. Despite the fact that VFTs were ranked $7^{\text {th }}$ in preference, results show that the trainers were highly reliable, frequently contacted, highly accessible and affordable, thus making it an effective source of information. Their relatively low rank was in part because only one-fifth of farmer groups had VFTs and therefore few farmers had access to them. Overall, interpersonal sources were more reliable than impersonal sources because they could provide practical evidence.

Results on training depict that more than $50 \%$ of the farmers have been trained on Napier grass, silage making, Rhodes grass, mineral supplementation, conservation of crop residues and concentrates. Women receive training in similar technologies as men but with fewer percentages of farmers trained, except on mineral supplementation. Farmers reportedly received training from DFBAs, MoAFLD, Non-governmental Organizations (NGOs), Farmer Training Centres (FTC), input dealers, the Kenya Agricultural Research Institute (KARI), VFT, neighbours, Agricultural Shows of Kenya (ASK) and through self-experimentation. 
With regard to information sharing, up to $72 \%$ of trained farmers shared information on technologies with other farmers, denoting the important role played by farmers in information dissemination. Majority of the trained farmers $(>30 \%)$ have shared information on three technologies. In general, male farmers and women in male-headed households tend to share information more frequently than those in female-headed households. The top three technologies shared by farmers were Napier grass (75.4\%), conservation of crop residues $(46.9 \%)$ and mineral supplementation $(39.3 \%)$.

After training, it is expected that farmers will adopt new technologies. This study examined the types of feed technologies practised by farmers. The three major technologies practised were mineral supplementation, Napier grass and concentrates, in that order. This was similar for both male and female farmers. However, there were significantly more men practising Rhodes grass, Lucerne and desmodium than women. Kikuyu grass appeared to be a prominent technology practised by more than $40 \%$ of the farmers. Evidently, traditional feeds are dominantly used. Comparing technologies trained with those shared/practised, results revealed a worrying trend on information diffusion among farmers. The percentages of farmers sharing and adopting Napier grass, conservation of crop residues and mineral supplementation technologies are similar. However, most farmers trained on Rhodes grass, Lucerne, silage making, hay baling and fodder shrubs did not adopt the technologies or share information with other farmers about them. This could be because of the cost involved in preparing the feed, lack of access to seeds, and the characteristics of the technology, for instance, the long wait before harvest.

Differentiating by sites, findings show that majority of the farmers $(>85 \%)$ in the UM areas of Rift valley, mainly Tanykina and Kapcheno sites in Nandi county used kikuyu grass. Similar findings were reported in Olkalou and Metkei sites in UH areas of Rift Valley. Farmers in Cherang'ani region of Rift valley which is also an UM area and those from Kieni in central region, a LM area, used Napier grass more than kikuyu grass. In LH areas, particularly Sot and Taragoon sites, the commonly used livestock feed technologies were conservation of crop residues and Napier grass. Out of all feed technologies practised by farmers, Napier grass, kikuyu grass and conservation of crop residues were the three most preferred feed technologies in that order. Feed technology preference differed across sites with farmers in Cherang'ani, Kapcheno, Metkei, Olkalou and Kieni preferring Napier grass while those in Tanykina and Sot preferring kikuyu grass. Taragoon farmers preferred conservation of crop residues. It is evident that farmers prefer and practise feed technologies that are locally available.

In order to evaluate the level of understanding of feed technologies, farmers were asked questions on various livestock feeds including Napier grass, hay, silage, fodder shrubs and Rhodes grass. The average score of farmers understanding of livestock feed technologies shows that farmers have a good understanding of the tested knowledge. Farmers scored highly on questions regarding Napier grass while low scores were recorded on fodder shrubs. Thus these findings further point out the reason why few farmers adopted fodder shrub technology. 
The findings confirm the importance and usefulness of the VFT approach. Although its preference ratings were not as high as those of CESPs, VFTs were widely appreciated. In addition, the VFT approach is more affordable than the CESPs, since VFTs receive no salaries. Nevertheless, the preference for CESPs highlights the fact that VFTs are not substitutes for extension staff, but rather, complement their services. Increased training of VFTs and the fostering of close links with extension can help in developing effective and efficient extension systems. 


\subsection{INTRODUCTION}

Improvement in agricultural production, productivity and sustainability is dependent on farmers' access and willingness to adopt improved technologies. Agricultural extension services support and facilitate farmers to solve problems and access information, skills and technologies to improve their wellbeing (Davis, 2008). Extension services also ensure that farmers' concerns are addressed by researchers, private institutions and other service providers. Agricultural extension has positive effects on technology adoption (Benin et al., 2007) and promotes agricultural development and productivity (Anderson and Feder, 2007; Davis et al., 2010; Benin et al., 2011). Further, extension enhances human and capital formation and sustainable natural resource management (Leeuwis, 2003 and Swanson, 2008) as well as improving rural incomes (Egziabher et al., 2013). It is evident that extension contributes directly to higher yields, innovations, poverty reduction, economic growth, environmental well-being and positive social returns.

Extension systems have been modified in recent years to meet the above mentioned roles. In the traditional approach to extension, knowledge is generated by researchers while the extension agents transfer the information to farmers. Farmers are in turn expected to adopt and improve their farming techniques. However, this extension system has been criticized as ineffective in meeting demands, especially of poor farmers (Rivera et al., 2001; Birner et al., 2006; Davis, 2008). Consequently, the extension systems were transformed from the earlier top-down models to more inclusive participatory extension approaches that are demanddriven and therefore focused on farmers' interests. These include farmer participatory research, farmer field schools, sustainable livelihood approach, innovation systems and farmer-to-farmer extension (FFE) approaches (Swanson and Rajalahti, 2010). Two other main modifications in extension systems were the inclusion of a broader range of topics in extension (e.g., marketing, promoting gender equality and organizing producers) and recognition that a broad range of actors, and not just government were involved in providing extension services (e.g., producer organizations, non-governmental organizations and agroinput suppliers). Improved extension systems have great potential for providing farmers with more and better information and strengthening their capacities to help them improve productivity and well-being (Sulaiman and Davis, 2012).

\subsection{Farmer-to-farmer extension}

The FFE approach involves training farmers who in turn train and share their knowledge and skills acquired with other farmers. The FFE approach is based on social and experiential learning theories (Bandura, 1993; Kolb, 1984) where ordinary farmers learn more from innovative neighbours, experiment and eventually adapt and use new technologies grounded in their socio-economic and biophysical circumstances. These farmer trainers are not usually paid for their services but receive free training and inputs from institutions implementing the projects (Lukuyu et al., 2012). Farmer trainers have been reported in Matata et al. (2013), Shrestha (2013), Lukuyu et al. (2012), Kiptot and Franzel (2013) and Kiptot et al. (2011) to be those farmers who:

- Put into practice the farming practices being promoted 
- Are able to experiment and implement new technologies

- Maintain a demonstration of good practices

- Train and coach other farmers and sometimes follow up on the progress of trained farmers.

Various studies (Wellard et al., 2013 and Shrestha, 2013) discovered that FFE was cost effective, enhanced access to extension services by the poor and disadvantaged groups and increased participation by farmers in planning. In addition, FFE helps in budgeting and implementation of agricultural development programmes. Besides, the approach empowers the disadvantaged by providing them with opportunities to become extension agents and increases adoption of new technologies. For example, about $80 \%$ of farmers in selected sites of Ghana, Uganda and Malawi were found to participate in training on soil conservation, tree planting, composting, crop storage and livestock production technologies offered through the FFE approach (Wellard et al., 2013). In another study, the number of farmers who adopted the System of Rice Intensification (SRI) in Ahero, Bunyala, West Kano and Mwea irrigation schemes in Kenya rose from 2 in 2009 to 2,000 farmers in 2010 as a result of learning from their trained counterparts (Mati, 2012).

FFE is highly favourably compared to other approaches because of advantages that farmer trainers have over other extension providers. Matata et al. (2013) note that farmers and trainers face similar constraints as they both have similar potential and aspirations. Thus, farmer trainers have the advantage of understanding the difficulties faced by fellow farmers because they have a more in-depth understanding of the local conditions and cultures compared to extension staff. Similarly, farmer trainers are readily available and accessible, hence can be approached by farmers whenever they are faced with any problem. The Volunteer Farmer Trainer (VFT) approach, a farmer-to-farmer extension approach, has been used by the East Africa Dairy Development (EADD) project to disseminate information on livestock feed technologies from farmer trainers to other farmers.

\subsection{An overview of the East Africa Dairy Development Project}

EADD is a regional development programme implemented in Kenya, Rwanda and Uganda by Heifer International, TechnoServe, International Livestock Research Institute (ILRI), the World Agroforestry Centre (ICRAF) and African Breeding Services Total Cattle Management (ABSTCM). The project was started in 2008 and aims at improving the lives of 179,000 families by doubling household dairy income by the $10^{\text {th }}$ year through integrated intervention in dairy production, market access and knowledge application. To achieve this, EADD works in 21 sites in Kenya. The sites, commonly referred to as hubs, are managed by dairy farmers' business associations (DFBAs) located in several counties in Central and Rift Valley regions. Each DFBA has about 3000-10,000 members. DFBAs provide services such as bulking and selling milk, financial services, technical support, artificial insemination (AI) services, extension services and credit.

DFBAs recently employed extension officers, commonly referred to as community extension service providers (CESPs). Initially, the officers were paid by EADD, but this function has gradually been taken over by DFBAs. CESPs provide training to the DFBA members. The 
training is organized at village level through groups commonly known as dairy management groups (DMGs). Training covers topics on feeds and feeding systems, breeding, animal health, milk quality, herd management, and group dynamics, among others. Apart from CESPs, farmers also receive training through VFTs in the project. The VFT approach was started by the World Agroforestry Centre, a partner of the EADD project spearheading the livestock feed component. As of June 2012, EADD had 1443 VFTs who were operating in Kenya. The VFTs are selected through a participatory process involving their DMGs composed of about 20 farmers, project dissemination facilitators and the DFBAs.

The selection criteria as discussed by Kiptot and Franzel (2013) and Kirui et al. (2009) include:

$\checkmark$ The ability to read and write

$\checkmark$ The ability to interpret extension materials to farmers

$\checkmark$ Membership of a farmer organization or cooperative society working with the EADD project

$\checkmark$ Being a dairy farmer

$\checkmark$ Having the willingness, interest and ability to disseminate new innovations and knowledge to others without pay

$\checkmark$ Being a resident in the community

$\checkmark$ Being willing to set aside land for setting up demonstrations.

After selection, VFTs are trained on feeds and feeding systems during an intensive, two-day course. They are supported to set up demonstration plots of various feed practices which include different grasses, fodder shrubs and herbaceous legumes. These demonstration plots are used as training grounds. VFTs are trained in feed conservation techniques which include silage making, hay baling, and management and utilization of crop residues. Project staff visit the VFTs from time to time and organize periodic training to improve their knowledge and skills. Some VFTs have the opportunity to participate in educational tours to innovative farms.

\subsection{A review of farmers' sources of information}

The demand for information has increased with increased complexities in agricultural production systems. Farmers need access to current information on modern agricultural technologies. There are various sources of information on agriculture. Farmers' choice of appropriate medium is crucial in information delivery (Cartmell et al., 2004). The choice of information channel is dependent on the reliability, affordability, accessibility and type of information delivered through the source. Muhammad (2005) has classified sources of information into impersonal and interpersonal sources. Interpersonal sources mainly involve face-to-face exchange of information between individuals while impersonal sources are mass media type of information delivery where one or a few persons address many other people at a time. These sources can be further grouped into traditional (radio, extension agents, television, demonstrations, written materials, farmer trainers) and modern sources (internet, mobile phones). 
Munyua (2000) notes that traditional media of agricultural information delivery have been used very successfully in developing countries. In particular, rural radio has played a major role in delivering agricultural messages. Similar studies have indicated that radio is a highly preferred source by farmers (Oriakhi and Okoedo-okojie, 2013; Oladeji et al., 2011).

Djojomartono and Pertini (1998) elucidate that radio and television are more appropriate for one-way communication and reach a large number of people faster with fairly simple ideas. This however limits interaction between farmers and disseminators. Djojomartono and Pertini (1998) argue that interpersonal communication, including extension agents, group meetings, community organizations and demonstrations are the best ways to teach and develop credibility. This is not without limitations in that sometimes their effectiveness is hindered by time, space, human resources and budgetary constraints. Farmers therefore use a combination of these information sources to gain knowledge on agricultural technologies. In their study, Farooq et al. (2007) found that the common and highly used sources of information in Pakistan were fellow farmers, printed material, television and the private sector.

Many studies based on agricultural information have focused on farmers' sources of information (Rehman et al., 2013; Farooq et al., 2007), information needs and search behaviours (Babu et al., 2012; Ali and Kumar, 2011; Metei and Devi, 2009), and socioeconomic factors influencing access to information sources (Çukur and Saner, 2013). There is inadequate information on the effectiveness of these information sources in dissemination of technologies. This study was intended to fill this knowledge gap by examining the effectiveness of the VFT approach as compared to other sources of information in dissemination of livestock feed technologies among dairy farmers in the EADD project sites in Kenya. Further analysis on information preferences, reliability, frequency, accessibility and affordability of the sources, training and technologies received and disseminated by farmers was carried out.

\subsection{Justification for the study}

Farmers obtain information on new agricultural technologies through different avenues. In this modern era, farmers need to use media that deliver timely and relevant information to improve their farming practices. Following the importance of VFTs and other information sources in extension delivery, assessing their effectiveness is worthwhile. The findings of this study provide insights to farmers, extension service providers, researchers and policy makers on the use of different sources of information for agricultural development. The results provide information on the training received by men and women farmers, adoption of technologies and sharing of information received between men and women farmers.

\subsection{Objectives of the study}

The objectives of the study include to:

1. Identify farmers' sources of information on livestock feed technologies and determine farmers' preferences. 
2. Identify the number and type of livestock feed technologies accessed by farmers through the VFTs and other sources of information.

3. Determine the number of farmers trained; the type of feed technologies that farmers have received training on and technologies practised.

4. Examine farmers' level of understanding of livestock feed technologies on which they had received training.

5. Determine the number of farmers sharing information with other farmers.

6. Assess the association between different sources of information and training, uptake and sharing of livestock feed technologies.

Data has been broken down by gender in order to assess the differences between men and women.

\subsection{METHODOLOGY}

\subsection{Evaluation framework}

Studies have used different approaches to assess the effectiveness of information sources in extension delivery. Wellard et al. (2013) measured the effectiveness of the farmer trainer approach by assessing how community-based extension approaches have contributed to improved food security and livelihoods of smallholders. The study considered factors such as training, number of farmers using soil conservation, tree planting, composting, crop storage, livestock production technologies, the state of household productivity and changes in their livelihood and assets. Ssemankula and Mutimba (2011) assessed effectiveness of the FFE model using increased technology uptake, increased production, increased food availability, multiplier effect in information sharing and increased sales of commodities.

In their study on assessing the effectiveness of mass media in disseminating agricultural technologies in Nigeria, Ariyo et al. (2013) looked at the extent to which the respondents had benefited from mass media in terms of adoption of agricultural technology. The study reported that $90 \%$ of farmers found mass media effective. In this study, effectiveness of VFT approach vis-a-vis other sources of information was assessed based on the following four aspects:

1. The proportion of farmers accessing information from the VFTs as well as other information sources.

2. The proportion of farmers trained by VFTs and other training institutions.

3. The number of women trained and the number of technologies implemented by women.

4. Farmers' level of understanding of livestock feed technologies.

5. The number of farmers sharing technologies with other farmers.

\subsection{Synopsis of EADD sites}

The EADD Kenya project is implemented in nine districts in Rift Valley region including: Bomet, Buret, Keiyo, Kipkelion, Marakwet, Molo, Nandi North, Uasin Gishu and West 
Pokot and two districts in Central region: Nyandarua and Nyeri districts. Currently, EADD has 21 sites in the two regions (EADD-MICCA Project Final Report, 2012). A site is defined in relation to dairy farmers limited company referred to as dairy farmer business associations (DFBAs) in the project. EADD sites include Tinderet, Olchobosen, Sirikwa, Cherang'ani, Lelan, Leichego, Taragoon, Kepkelion, Cherobu, Kokiche, Metkei, Kapcherio, Olkalou, Siongoroi, Olenguruone, Sot, Chepkorio, Kabiyet, Kaptuma, Mweiga and Tanyikina. These sites, commonly known as hubs, have chilling plants that store and sell milk and provide other services on agro-veterinary supplies and improved fodder. The hubs are managed by DFBAs which are shareholders in the plants and are located within the community. The total number of registered farmers under EADD project in Kenya was 107,566 as at 2012.

\subsection{Study area}

The study sites are located in North Rift, South Rift, Central Rift and Central regions of Kenya. Central region and South Rift Valley are characterized by bimodal type of rainfall with the short rains falling in October to December and the long rains in March to May. North Rift receives a unimodal type of rainfall with a long rainy season and a short dry season between November and February. Dairy farming is prevalent in all the study sites. The cattle feeding systems practised range from intensive to extensive systems where cattle graze freely on private/public land, in paddocks or are tethered. The intensive feeding system is prevalent in Central Rift and Central region of Kenya while pure grazing is common in the North and South Rift (Kiptot and Franzel, 2012). Nearly all dairy farmers also cultivate several crops for both subsistence and to earn cash. The major crops grown in Central Kenya and Central Rift are maize, beans and Irish potatoes with flowers dominating in the cash crop sector. In the North Rift regions, beans, maize, wheat, sweet potatoes, sorghum, vegetables and fruits such as passion can be found in most farming households. The South Rift region supports the growing of maize, beans, sweet potatoes, bananas, sorghum and finger millet. The main cash crops are tea and pyrethrum (Lukuyu et al., 2011).

\subsection{Sampling procedure}

\subsubsection{Sampling technique}

Selection of study DFBAs was based on their year of formation and agro-ecological zones (AEZ). The oldest DFBA was formed in 2008 while the most recent was formed in 2012. To avoid bias due to the period of implementation of the program, two DFBAs that were formed after 2010 were dropped, leaving a total of 19 DFBAs. Afterwards, the location of the DFBAs was established. The DFBAs were located in four AEZs classified as Upper Midland (UM), Upper Highland (UH), Lower Highland (LH) and Lower Midland (LM) in South Rift, North Rift and Central regions of Kenya. A number of DFBAs were randomly selected proportionate to the number of DFBAs per AEZ. Consequently, two DFBAs were selected from $\mathrm{UH}$, two from $\mathrm{LH}$, three from UM and one DFBA from LM. This gave a total of eight DFBAs for the study. Finally, dairy productivity was measured using scores defined by EADD and applied at the DFBA level. Sample sites were also checked for their production stage scores, that is, their assessed productivity levels. The lowest score is 1 whereas the highest is 5. The selected DFBAs showed varied production scores ranging from 2-4 and 
representative of the 21 sites. Therefore, no changes were made in the sampling. The DFBAs included Cherang'ani, Tanykina, Kapcheno, Metkei, Olkalou, Taragoon, Sot and Kieni.

The lists of farmers who are members of the DFBAs were obtained from EADD and systematic sampling design was carried out to sample households for the study. The farmers were sampled proportionate to the population size of the DFBA. The farmers selected for the interviews consisted of both men and women. A replacement list was obtained using the above procedure to replace farmers who were not available during the interview. The location of farmers interviewed is shown in Figure 1 and the distribution of farmers across DFBAs and counties are as presented in Table 2.

\subsubsection{Sample size}

The selected sites had a total of 41,889 farmers. A sample size of 384 households was obtained using Cochran's (1977) formula given as:

$n=\frac{z^{2} * p q}{E^{2}}$

Hence

$n=\frac{1.96^{2} * 0.5 * 0.5}{0.05^{2}}=384$

Where;

$\mathrm{Z}$ is the $\mathrm{Z}$ value at $95 \%$ confidence level given as $1.96, \mathrm{p}=$ proportion of the population containing the major interest given as $0.5, \mathrm{q}=1-\mathrm{p}=0.5$ and $\mathrm{E}=$ acceptable/allowable error of 0.05 . A summary of the selected study sites and the sample size is as provided in Table 1 below.

The 41,889 farmers were organized into about 2,094 DMGs, assuming 20 farmers per group. Comparing the sample size obtained per site with the number of VFTs available per site (Table 1), it is estimated that only $19.7 \%$ of the groups, or about 1 in 5 had a VFT. 


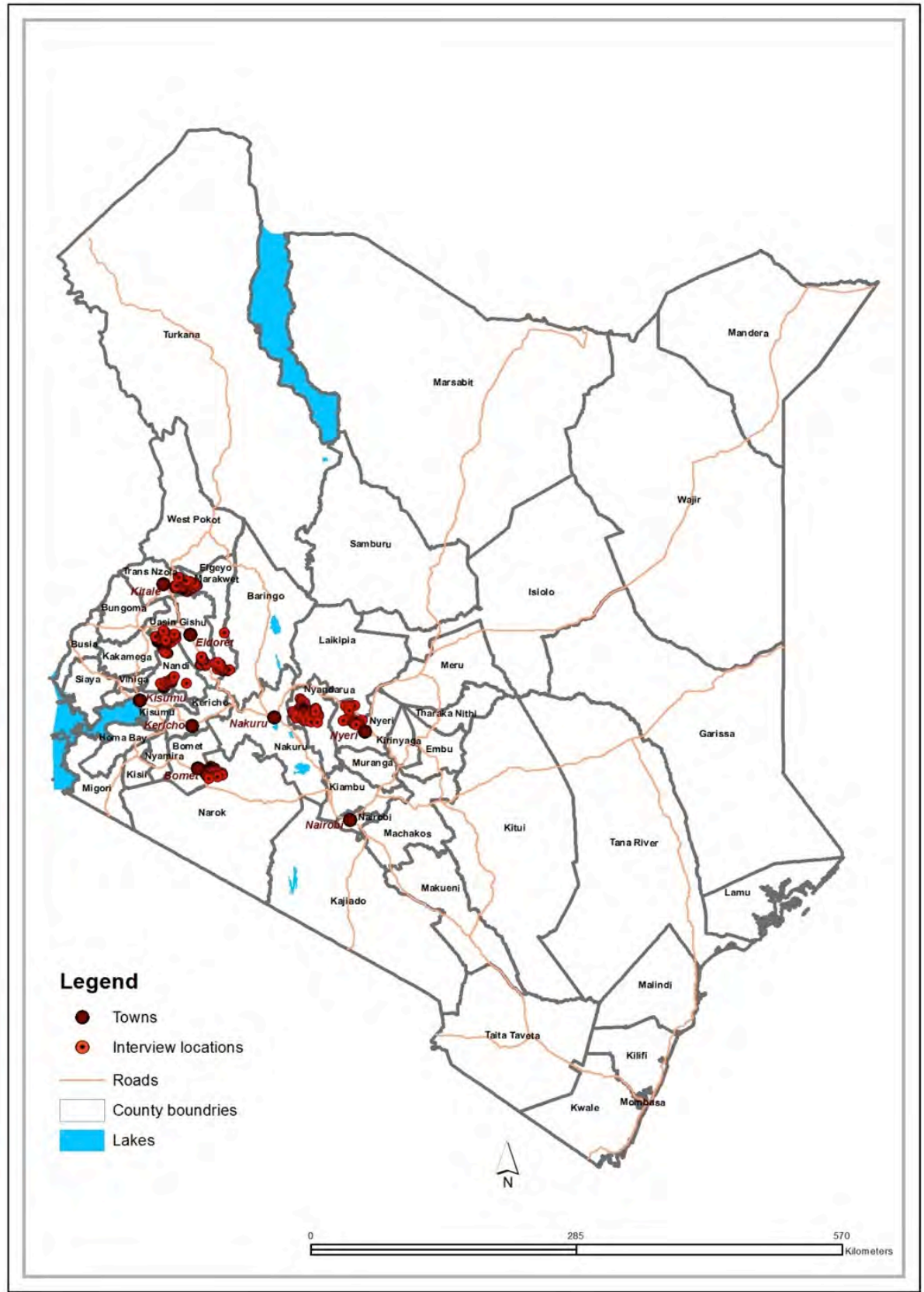

Figure 1: Interview locations 
Table 1: Summary of sampled sites

\begin{tabular}{|c|c|c|c|c|c|c|c|c|c|c|}
\hline AEZ & $\begin{array}{l}\text { No. } \\
\text { sites }\end{array}$ & & $\begin{array}{l}\text { idy sites } \\
\text { ected }\end{array}$ & County & Region & Year of formation & Total population & $\begin{array}{l}\text { Production } \\
\text { stage score }\end{array}$ & Sample size & $\begin{array}{l}\text { No. of } \\
\text { VFTs }\end{array}$ \\
\hline \multirow[t]{3}{*}{ UM } & 12 & 3 & Cherang'ani & Trans Nzoia & North Rift Valley & 2010 & 5905 & 2 & 59 & 143 \\
\hline & & & Tanykina & Nandi & North Rift Valley & 2008 & 13,004 & 4 & 131 & 72 \\
\hline & & & Kapcheno & Nandi & South Rift Valley & 2010 & 3352 & 3 & 34 & 58 \\
\hline \multirow[t]{2}{*}{$\mathrm{UH}$} & 4 & 2 & Metkei & E.Marakwet & North Rift Valley & 2009 & 1866 & 4 & 19 & 25 \\
\hline & & & Olkalou & Nyandarua & Central & 2008 & 6633 & 3 & 67 & 38 \\
\hline \multirow[t]{2}{*}{ LH } & 3 & 2 & Taragoon & Uasin Gishu & North Rift Valley & 2010 & 1972 & 2 & 20 & 10 \\
\hline & & & Sot & Bomet & South Rift Valley & 2008 & 5981 & 3 & 60 & 20 \\
\hline LM & 2 & 1 & Kieni & Nyeri & Central & 2008 & 3176 & 3 & 32 & 76 \\
\hline Total & 21 & 8 & & & & & 41,889 & & 422 & 412 \\
\hline
\end{tabular}

*Highest production stage score is 5 , lowest score is 1 


\subsection{Data collection and analysis}

A structured questionnaire was used to obtain data from sampled farmers. The questionnaire captured information in line with the specified objectives as mentioned in section 1.5. Questions covered the household socio-economic characteristics, livestock production, gender involvement and information sources for livestock feed technologies. Data entry and analysis was carried out using SPSS software. Descriptive statistics such as frequency counts, percentages, mean and standard deviations were used to address the four objectives. Farmers' preferences of sources of information were also established. This was done by rating the sources as high, medium and low in preference. Scores of 3, 2 and 1 were then assigned to high, medium and low preferred sources, respectively. The scores were multiplied by the frequencies and the row sum calculated to obtain total score. The total score gave the ranks which indicated farmers' preference in terms of extent of use and quality of a particular source. Farmers who did not score were assigned a 0 score.

\subsection{RESULTS}

\subsection{Demographic and socio-economic characteristics of farmers}

A total of 233 (55\%) male and 190 (45\%) female farmers were interviewed. Farmers' main demographic and socio-economic characteristics are shown in Table 2. All farmers had an average age of 46.3 years but female farmers were slightly younger ( 45.6 years) than their male counterparts ( 46.8 years). About $18.7 \%$ of the farmers were in the youth category (1834 years), $61.7 \%$ were of middle age (35-59 years) while $19.6 \%$ were elderly ( $>59$ years). Dairy farming in the sampled sites is mainly practised by middle-aged people. Youth are less involved perhaps because they lack the needed capital or because they do not find dairy farming enticing.

Most of the farmers were married (83.2\%). Disaggregating by gender, it can be seen that there were more married men than women. The difference was highly significant. Farmers had an average of 9.5 years of schooling, which indicates that they had attained a minimum of primary school education and some years of post-primary education. Compared to their female counterparts, male farmers had significantly more years of education. Education positively influences decision-making on agricultural production and therefore male farmers are expected to be better decision makers than their female counterparts. The results on age correspond to the number of years of farming experience where all farmers had fairly long experience in dairy farming (14 years). However, female farmers reportedly had a year less of experience compared to their male counterparts. Most of the farmers were trained on improved livestock feed technologies (90\%) and were therefore aware of these technologies. In terms of group membership, there were more female farmers participating in groups $(67.4 \%)$ than male farmers (57.1\%). Groups create a forum for exchange of information among farmers and are therefore critical in facilitating agricultural development. 
Table 2: Socio-economic characteristics of individual farmers interviewed

\begin{tabular}{|c|c|c|c|c|c|}
\hline Variable & $\begin{array}{l}\text { Male } \\
(n=233)\end{array}$ & $\begin{array}{l}\text { Female } \\
(n=190)\end{array}$ & $\begin{array}{l}\text { All } \\
(n=423)\end{array}$ & t/ test & $\begin{array}{l}\text { chi } \\
\text { square }\end{array}$ \\
\hline \multicolumn{6}{|l|}{ Farmer characteristics } \\
\hline Age & $46.8(13.6)$ & $45.6(13.37)$ & $\begin{array}{l}46.3 \\
(13.49)\end{array}$ & 0.928 & 0.928 \\
\hline$\%$ age groups & & & & & \\
\hline $15-34$ years & $19.3(0.03)$ & $17.9(0.03)$ & $18.7(0.02)$ & & 12.89 \\
\hline $35-59$ years & $59.7(0.03)$ & $64.2(0.03)$ & $61.7(0.02)$ & & 22.31 \\
\hline$>59$ years & $21.0(0.03)$ & $17.9(0.03)$ & $19.6(0.02)$ & & $\begin{array}{l}24.48 \\
11.732 * *\end{array}$ \\
\hline Marital Status & & & & & $*$ \\
\hline Never married (\%) & 11.2 & 11.1 & 11.1 & & \\
\hline Married (\%) & 86.3 & 79.5 & 83.2 & & \\
\hline Widowed (\%) & 2.2 & 9.7 & 5.4 & & \\
\hline Divorced/separated $(\%)$ & 0.4 & 0 & 0.2 & & \\
\hline Education & $10.1(3.55)$ & $8.7(3.97)$ & $9.5(3.81)$ & $3.940 * * *$ & \\
\hline $\begin{array}{l}\text { Experience in dairy } \\
\text { (years) }\end{array}$ & $14.7(11.32)$ & $14.3(10.89)$ & $\begin{array}{l}14.5 \\
(11.08)\end{array}$ & 0.358 & \\
\hline Group membership (\%) & 57.1 & 67.4 & 61.7 & & $4.687 * *$ \\
\hline
\end{tabular}

About $9 \%$ of the households were female-headed. Women in female-headed households were 7 years older than women in male-headed households thus explaining why women in femaleheaded households had more years of experience in dairy farming (Table 3). Old age is linked to reluctance to adopt new technologies and thus female-headed households may be less willing to try modern livestock feed technologies.

Women in female-headed households were less educated than women in male-headed households and the difference was significant. The low levels of education could have limited the participation of female heads in training as indicated by the low percentage of trained farmers in this category. The difference in training between the two categories was highly significant. Lack of training could have a negative impact on farmers' level of understanding of livestock feed technologies and farmers' access to information on livestock feeds. There were no significant differences in group membership between female heads and women in male-headed households. Overall, women in female-headed households were older, more experienced in dairy, less trained and less educated compared to females in male-headed households. 
Table 3: Socio-economic characteristics of women farmers interviewed

\begin{tabular}{lllll}
\hline Variable & $\begin{array}{l}\text { Women in female- } \\
\text { headed households } \\
(\mathbf{N = 3 9 )}\end{array}$ & $\begin{array}{l}\text { Women in male- } \\
\text { headed } \\
\text { households } \\
\mathbf{( N = 1 5 1 )}\end{array}$ & $\begin{array}{l}\text { t/test } \\
\text { square }\end{array}$ \\
\hline Age & $50.8(15.2)$ & $44.2(12.5)$ & $-2.778^{* *}$ & \\
Education & $7.5(4.8)$ & $9(3.6)$ & $2.119^{* *}$ & \\
Experience in dairy & $17(13.4)$ & $13.6(10)$ & $-1.78^{*}$ & \\
$\begin{array}{l}\text { Group membership } \\
(\%)\end{array}$ & $71.8(0.07)$ & $66.2(0.03)$ & & 0.437 \\
\hline
\end{tabular}

$* * * \mathbf{p}<0.01,{ }^{* *} \mathbf{p}<0.05,{ }^{*} \mathbf{p}<0.1$; figures in parenthesis present the standard deviations

\subsubsection{Participation in groups}

As indicated in Table 2 above, $61.7 \%$ of the farmers were in groups. The groups were either agricultural (livestock, horticulture) or non-agricultural (e.g. savings and credit, welfare, religious) (Table 4). Majority of the farmers (55.3\%) participated in savings and credit groups. Participation in such groups enhances farmers' ability to access credit from microfinance organizations, marketing agents or input suppliers, which in turn boosts investment in agriculture. Other important groups were agricultural (44.7\% of farmers) and welfare groups (38.5\% of farmers). Agricultural groups are considered vital sources of information mostly through trainers or other farmers. With regard to gender, more female farmers participated in savings and credit groups than male farmers who were inclined to agricultural, welfare and community groups. Unlike men, women farmers often lack physical collateral which limits their access to credit facilities from formal institutions. Thus, most of them opt for informal savings and credit schemes such as group lending.

Table 4: Farmers' membership in groups

\begin{tabular}{llll}
\hline Type of group & \% male $(\mathbf{N}=\mathbf{1 3 5})$ & \% female $(\mathbf{N}=\mathbf{1 2 7})$ & Total $\mathbf{( N = 2 6 2 )}$ \\
\hline Savings and credit & 43.0 & $68.5^{* * *}$ & 55.3 \\
Agricultural & 54.1 & $34.6^{* * *}$ & 44.7 \\
Welfare & 44.4 & $32.3^{*}$ & 38.5 \\
Religious & 14.8 & 11.0 & 13.0 \\
Education & 11.1 & 7.9 & 9.5 \\
Community & 13.3 & $4.7^{* *}$ & 9.2 \\
Clan & 5.9 & 2.4 & 4.2 \\
\hline$* * * \mathbf{p}<\mathbf{0 . 0 1},{ }^{* *} \mathbf{p}<\mathbf{0 . 0 5}, * \mathbf{p}<\mathbf{0 . 1 :} \mathbf{~ N B : ~} \mathbf{N}$ refers to number of farmers in groups, $\mathbf{1 6 1}$ farmers did not participate in any \\
group
\end{tabular}

Generally, women in male-headed households did not differ significantly from those in female-headed households in terms of participation in various groups, except that the former were less active in educational groups (Table 5). 
Table 5: Percentage of female farmers participating in groups

\begin{tabular}{lll}
\hline Group type & $\begin{array}{l}\text { \%o of women farmers in } \\
\text { female-headed households } \\
\text { (N=28) }\end{array}$ & $\begin{array}{l}\text { \% women farmers in male } \\
\text { headed households (99) }\end{array}$ \\
\hline Savings and credit & 67.8 & 68.7 \\
Agricultural & 32 & 35.4 \\
Welfare & 35.7 & 31.3 \\
Religious & 7.1 & 12.1 \\
Education & 10.7 & 0.07 \\
Community & 0 & 0.06 \\
Clan & 3.6 & 0.02 \\
\hline
\end{tabular}

$\mathrm{N}$ represents farmers in groups; 63 female farmers were not in groups

Farmers were engaged in diverse enterprises and many of these are accounted for in the groups to which they belonged. A large proportion of the farmers were involved in dairy production groups $(55 \%)$ which indicates that the sample was drawn from members of a dairy cooperative (Table 6). Membership in other enterprise-related groups included livestock feed production $(23.9 \%)$, horticulture (18.8\%), dairy goat (17.1) savings and credit $(16.2 \%)$, subsistence farming $(13.7 \%)$ and poultry $(12 \%)$. The enterprises practised in agricultural groups did not differ between male and female farmers. Participation in various agricultural group enterprises was similar between male and female farmers. However, a significantly higher percentage of male farmers engaged in welfare support activities.

Table 6: Percentage of farmers belonging to groups concerned with specific agricultural enterprises

\begin{tabular}{llll}
\hline Enterprise & Male $(\mathbf{N}=\mathbf{7 3})$ & Female $(\mathbf{N}=\mathbf{4 4})$ & Total $(\mathbf{N}=\mathbf{1 1 7})$ \\
\hline Dairy cattle & 53.4 & 59.1 & 55.6 \\
Livestock feed production & 21.9 & 27.3 & 23.9 \\
Horticulture & 20.5 & 15.9 & 18.8 \\
Dairy goat & 15.1 & 20.5 & 17.1 \\
Savings and credit & 12.3 & 22.7 & 16.2 \\
Subsistence farming & 15.1 & 11.4 & 13.7 \\
Poultry & 8.2 & 18.2 & 12.0 \\
Welfare support & 13.7 & $0.0 * *$ & 8.5 \\
Cash crop & 8.2 & 6.8 & 7.7 \\
Agroforestry & 4.1 & 6.8 & 5.1 \\
Sheep & 1.4 & 2.3 & 1.7 \\
Bee keeping & 2.7 & 0.0 & 1.7 \\
\hline
\end{tabular}

$* * * \mathbf{p}<0.01, * * \mathrm{p}<0.05, * \mathrm{p}<0.1 ; \mathrm{N}$ refers to number of farmers in agricultural groups, 306 farmers were not in agricultural groups

Farmers participate in agricultural groups for different reasons. The data in Table 7 shows that the major benefits derived from participating in agricultural groups include access to information (90.6\%) and collective marketing (80.3\%). Access to ready market was of greater importance to male farmers than female farmers. Female farmers on the other hand, 
mentioned welfare support as a major benefit. Evidently, male farmers participated in groups to access markets while women farmers participated in groups for social gains.

Table 7: Benefits derived by farmers from participating in agricultural groups

\begin{tabular}{llll}
\hline Benefit & Male $(\mathbf{N}=\mathbf{7 3})$ & Female $(\mathbf{N}=44)$ & Total $(\mathbf{N}=117)$ \\
\hline Information & 91.8 & 88.6 & 90.6 \\
Collective marketing & 80.8 & 79.5 & 80.3 \\
Credit/loan & 56.2 & 59.1 & 57.3 \\
Ready market & 60.3 & $38.6^{* *}$ & 52.1 \\
Input & 45.2 & 52.3 & 47.9 \\
Welfare & 41.1 & $56.8^{*}$ & 47.0 \\
\hline
\end{tabular}

$\mathbf{N}$ refers to number of farmers in agricultural groups, 306 farmers were not in agricultural groups

\subsubsection{Household wealth characteristics}

The housing material was used as a proxy for wealth. About $92.6 \%$ of the farmers used iron sheets for roofing and thus were considered middle-income. Obviously, the middle class was overrepresented in the sample. Dairy farmers are thought to be of medium wealth given that they could afford to own a cow. Only $6.9 \%$ of the farmers used thatch for roofing, thus representing poor farmers in the study sites. About $0.5 \%$ of the farmers had tiled roofs. These formed the wealthy category.

With regard to land ownership, Table 8 indicates that both male- and female-headed households had an average land size of 2.6ha. Male-headed households had a mean of 3.7 cows with the female-headed households owning 3.3 cows. There were no significant differences in land and cow ownership between male- and female-headed households. Likewise, the proportion of households with cross-bred (87.5\%), pure-bred $(12.3 \%)$ and local-bred (4.5\%) cattle was similar among male- and female-headed households. The high percentage of households owning cross-breed cows in the project sites could be linked to increased awareness of the use of artificial insemination (AI) promoted by the EADD project. Farmers receive AI services from trained extension staff in the DFBAs.

Table 8: Farm characteristics of household heads

\begin{tabular}{|c|c|c|c|}
\hline Variable & $\begin{array}{l}\text { Male-headed } \\
\text { households }(\mathrm{N}=384)\end{array}$ & $\begin{array}{l}\text { Female-headed } \\
\text { households } \\
(\mathrm{N}=39)\end{array}$ & $\begin{array}{l}\text { Total } \\
(\mathrm{N}=423)\end{array}$ \\
\hline Land size (ha) & $2.6(1.8)$ & $2.6(1.8)$ & $2.6(1.8)$ \\
\hline Number of cows & $3.7(2.98)$ & $3.3(2.0)$ & $3.65(2.9)$ \\
\hline \multicolumn{4}{|c|}{ Cow breed owned (\%) } \\
\hline Local & $4.4(0.01)$ & $5.1(0.03)$ & $4.5(0.02)$ \\
\hline Cross & $87.8(0.01)$ & $84.6(0.06)$ & $\begin{array}{l}87.5 \\
(0.02) \\
12.3\end{array}$ \\
\hline Pure & $12.2(0.02)$ & $12.8(0.05)$ & $(0.03)$ \\
\hline
\end{tabular}

Given the diversity of study sites in terms of population size and density, agro-ecological conditions and culture, the study analysed land size and number of cows owned by site. 
Figure 2 shows that land and cow ownership varied across sites. Households in Taragoon, Metkei, Tanykina and Cherang'ani had relatively larger land sizes than other sites, with households in Kapcheno and Kieni sites owning the smallest land sizes. The number of cows owned by households was high in Taragoon and Olkalou. Households in Sot and Kapcheno sites had the least number of cows.

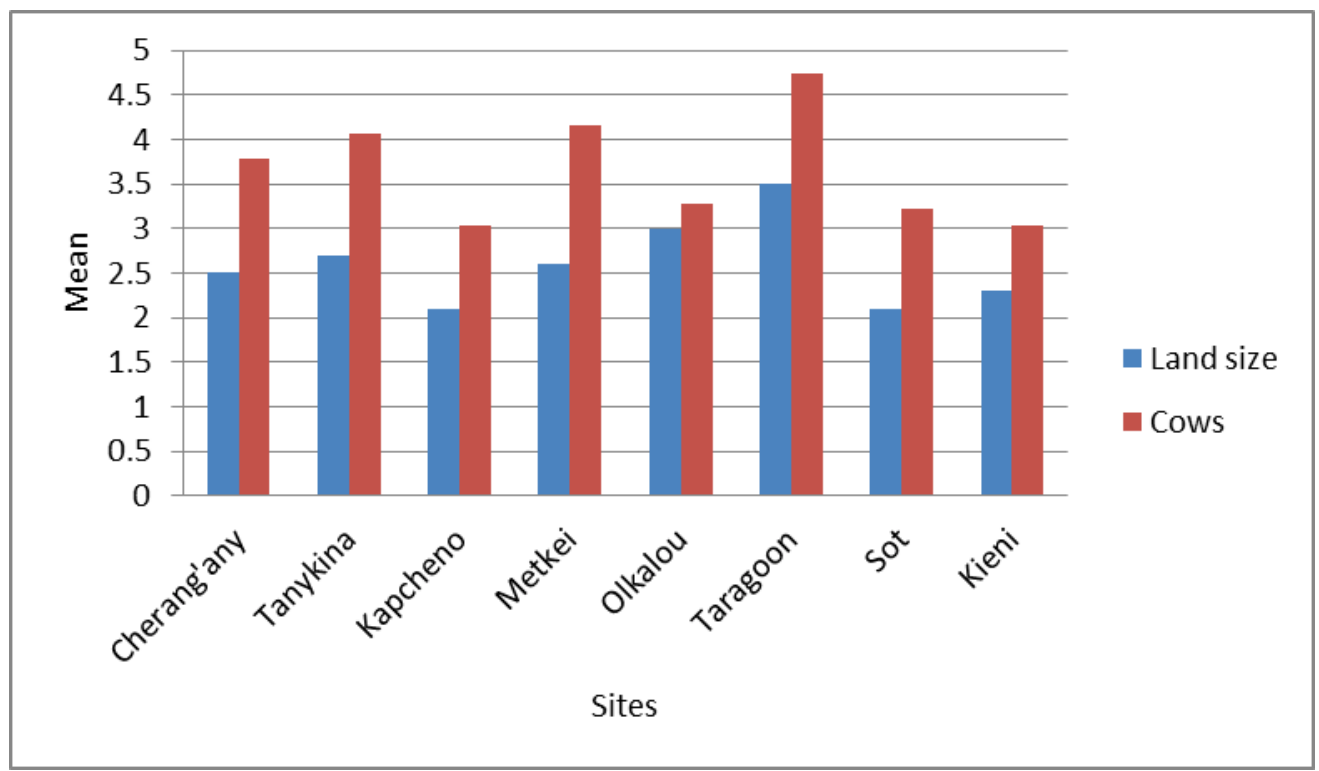

\section{Figure 2: Land size (ha) and cow ownership by site}

\subsubsection{Livestock type owned and livelihood sources of households}

Dairy cattle, poultry and sheep comprised the three major livestock kept by $100 \%, 83.9 \%$ and $50.1 \%$ of households respectively (Table 9). Specifically, farmers owned an average of 3.6 cows, 12.8 poultry birds and 5.8 sheep. Households owned more poultry and sheep compared to cattle because they require smaller spaces and are easy to manage. Poultry and sheep are a good alternative source of income for farmers during low milk production seasons, and thus are mainly kept to diversify income sources.

Table 9: Number and type of livestock owned by farmers

\begin{tabular}{lll}
\hline Type of livestock & \% of all households(N=423) & Mean (standard deviation) \\
\hline Dairy & 100 & $3.6(2.91)$ \\
Poultry & 83.9 & $12.8(8.59)$ \\
Sheep & 50.1 & $5.8(4.21)$ \\
Beef & 28.4 & $1.9(1.44)$ \\
Goats & 15.8 & $4.6(3.5)$ \\
Donkeys & 14.7 & $1.2(0.59)$ \\
Bees & 8.0 & $4.8(3.99)$ \\
Rabbit & 5.2 & $7.5(5.18)$ \\
Pigs & 0 & 0 \\
\hline
\end{tabular}

The livelihood sources of interviewed households are presented in Figure 3. All farmers (100\%) practised dairy and subsistence farming and hence the two are the most important sources of livelihood. Other main livelihood sources identified by farming households 
included poultry farming (77.3\%) sheep rearing (44.2\%) and cash crop farming (33.3\%) (i.e., tea in Kapcheno and sugarcane in Tanykina).

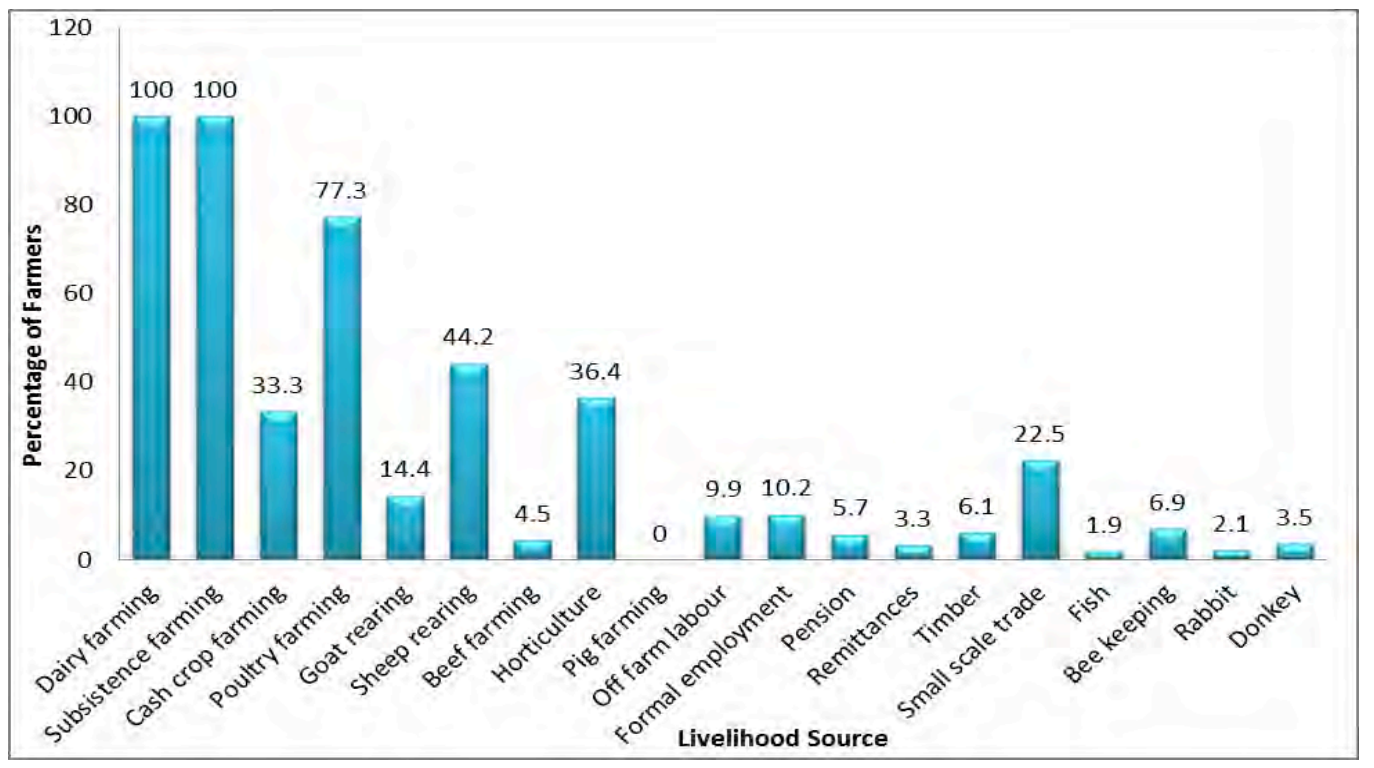

Figure 3: Livelihood sources

\subsection{Sources of information on livestock feed technologies}

In response to the question on the sources of information accessed, farmers identified 24 different sources that they used (Table 10). Almost two-thirds of those interviewed had access to information from radio which formed the most accessed source of information. This was followed by CESPs, neighbours, field days and MoALFD, each used by about $44 \%$ to $50 \%$ of the farmers. With regard to gender, both male and female farmers accessed information from similar sources. However, male farmers reported field days and CESPs as their second and third most accessed sources respectively, while female farmers reported CESPs and neighbours. Additionally, a comparatively higher percentage of male farmers had access to a number of information sources. Examples include radio, field days, agricultural shows, skilled farmers, written materials, demonstrations, newspapers, breeders' shows, mobile phones and posters. 
Table 10: Percentage of farmers accessing information from different sources by gender

\begin{tabular}{llll}
\hline Source of Information & $\begin{array}{l}\text { \%Male } \\
(\mathbf{N = 2 3 3 )}\end{array}$ & $\begin{array}{l}\text { \%Female } \\
\mathbf{( N = 1 9 0 )}\end{array}$ & $\begin{array}{l}\text { \%Total } \\
\mathbf{( N = 4 2 3 )}\end{array}$ \\
\hline Radio & 69.5 & 55.8 & $63.4^{* *}$ \\
CESPs & 46.4 & 52.6 & 49.2 \\
Neighbours ${ }^{1}$ & 45.9 & 46.8 & 46.3 \\
Field days & 53.6 & 35.3 & $45.4^{* * *}$ \\
MoALFD & 45.1 & 42.6 & 44.2 \\
VFTs & 29.6 & 23.2 & 26.7 \\
Agricultural shows (ASK) & 32.2 & 16.3 & $25.1^{* * *}$ \\
Input dealers & 20.6 & 24.2 & 22.2 \\
Exchange visits & 23.6 & 20.5 & 22.2 \\
Farmer Cooperatives & 19.7 & 24.2 & 21.7 \\
Skilled farmers ${ }^{2}$ & 21.9 & 15.3 & $18.9^{*}$ \\
TV & 15.9 & 10.5 & 13.5 \\
Written materials & 15.5 & 8.9 & $12.5^{* *}$ \\
Demonstrations & 15.0 & 7.9 & $11.8^{* *}$ \\
NGO & 11.2 & 8.9 & 10.2 \\
Farmers organizations/groups other than DMGs & 12.0 & 7.9 & 10.2 \\
Newspapers & 11.2 & 5.3 & $8.5^{* *}$ \\
Private service providers & 9.4 & 6.3 & 8.0 \\
Breeders show & 9.9 & 3.2 & $6.9^{* *}$ \\
KARI & 3.9 & 5.3 & 4.5 \\
Mobile phone & 6.9 & 1.6 & $4.5^{* *}$ \\
Posters & 6.4 & 2.1 & $4.5^{* *}$ \\
Internet & 3.0 & 1.6 & 2.4 \\
Commodity traders & 1.3 & 0.0 & 0.7 \\
\hline
\end{tabular}
$* * * p<0.01,{ }^{* *} p<0.05,{ }^{*} p<0.1$

Compared to other sources, the VFTs were ranked $6^{\text {th }}$ overall and were accessed by $26.7 \%$ of farmers. Given that only $19.7 \%$ of DMGs had volunteer farmer trainers, the data shows that VFTs were an important source of information in DMGs where they were available, and in a limited number of other DMGs as well. Male farmers ranked VFTs $7^{\text {th }}$ while female farmers ranked it $8^{\text {th }}$.

Disaggregating by household type, results in Table 11 show that a higher proportion of women in male-headed households had access to the MoALFD and private service providers. The VFTs were ranked $5^{\text {th }}$ by women in female-headed households and $8^{\text {th }}$ by women in male-headed households.

\footnotetext{
${ }^{1}$ Neighbours include those who reside near the respondent, normally in the next farm or house.

${ }^{2}$ Skilled farmers are farmers who have expertise in agricultural technologies and are located either within or outside the local community
} 
Table 11: Women's access to sources of information

\begin{tabular}{lll}
\hline Source of information & $\begin{array}{l}\text { \% women in female- } \\
\text { headed households } \\
\text { (N=39) }\end{array}$ & $\begin{array}{l}\text { \% female in male- } \\
\text { headed households (151) }\end{array}$ \\
\hline Radio & 56.4 & \\
CESPs & 51.3 & 55.6 \\
Neighbours & 48.7 & 53 \\
Field days & 28.2 & 46.4 \\
MoALFD & 25.6 & 37.1 \\
VFTs & 25.6 & $47^{* *}$ \\
Agricultural shows (ASK) & 12.8 & 22.5 \\
Input dealers & 25.6 & 17.2 \\
Exchange visits & 17.9 & 23.8 \\
Farmer Cooperatives & 25.6 & 21.2 \\
Skilled farmers & 17.9 & 23.8 \\
TV & 7.8 & 14.6 \\
Written materials & 7.8 & 11.3 \\
Demonstrations & 7.8 & 9.2 \\
NGO & 7.8 & 7.9 \\
Farmers organizations/groups & 7.8 & 9.3 \\
Newspapers & 2.6 & 7.9 \\
Private service providers & 12.8 & 5.9 \\
Breeders show & 5.1 & $4.6^{*}$ \\
KARI & 2.5 & 2.6 \\
Mobile phone & 0 & 6 \\
Posters & 2.5 & 2 \\
Internet & 2.5 & 1.9 \\
Commodity traders & 0 & 1.3 \\
$* * * *$ p $<\mathbf{0 . 0 1}, * *$ p $<\mathbf{0 . 0 5}, * \mathrm{p}<\mathbf{0 . 1}$ & & 0 \\
& &
\end{tabular}

Table 12 below illustrates the considerable differences in access to sources of information across farmers in different DFBAs. It is apparent that CESPs were the most accessed source of information in Cherang'ani (80.3\%), Metkei (47.4\%) and Sot (68.3\%). Radio was accessed by more than $45 \%$ of the farmers in Tanykina, Kapcheno, Metkei, Olkalou and Taragoon, while the MoALFD was predominant in Kieni. Relative to other sources, VFTs featured $2^{\text {nd }}$ in Kieni and Sot, $3^{\text {rd }}$ in Kapcheno, and were also accessed in other sites. 
Table 12: Farmers access to sources of information by DFBA

\begin{tabular}{|c|c|c|c|c|c|c|c|c|}
\hline Source & $\begin{array}{l}\text { Cherang'ani } \\
(\mathrm{N}=61)\end{array}$ & Tanykina $(\mathrm{N}=131)$ & Kapcheno $(N=34)$ & Metkei $(\mathrm{N}=19)$ & Olkalou $(\mathrm{N}=67)$ & Taragoon $(\mathrm{N}=19)$ & Sot $(N=60)$ & Kieni $(N=32)$ \\
\hline MOALFD & 73.8 & 8.4 & 35.3 & 31.6 & 29.9 & 36.8 & 58.3 & 81.3 \\
\hline $\mathrm{NGO}$ & 11.5 & 0.8 & 44.1 & 5.3 & 9 & 5.3 & 8.3 & 12.5 \\
\hline Farmer organizations & 11.5 & 6.9 & 5.9 & 0 & 6 & 26.3 & 15 & 15.6 \\
\hline KARI & 18.0 & 0 & 0 & 5.3 & 3 & 15.8 & 0 & 6.3 \\
\hline Farmer cooperatives & 4.9 & 32.8 & 5.9 & 10.5 & 21 & 21.1 & 20 & 28.1 \\
\hline VFTs & 27.9 & 6.9 & 44.2 & 10.5 & 14.9 & 15.8 & 46.7 & 62.5 \\
\hline CESPs & 80.3 & 22.1 & 35.3 & 47.4 & 35.8 & 31.6 & 68.3 & 43.8 \\
\hline Skilled farmers & 29.5 & 17.6 & 11.8 & 10.5 & 22.4 & 26.3 & 11.7 & 6.3 \\
\hline Neighbours & 49.2 & 65.7 & 52.9 & 26.3 & 28.4 & 26.3 & 13.3 & 50 \\
\hline Input dealers & 3.8 & 16.8 & 0 & 0 & 37.3 & 31.6 & 33.3 & 28.1 \\
\hline Commodity traders & 0 & 0.8 & 0 & 0 & 0 & 0 & 0 & 3.1 \\
\hline Private service providers & 9.8 & 0.8 & 0 & 5.3 & 4.5 & 21.1 & 18.3 & 21.9 \\
\hline Mobile phone & 1.6 & 9.9 & 2.9 & 5.3 & 0 & 0 & 0 & 0 \\
\hline Radio & 34.4 & 69.5 & 79.4 & 47.4 & 49.3 & 47.4 & 60 & 56.3 \\
\hline Television & 8.2 & 20.6 & 23.5 & 15.8 & 3 & 10.5 & 5 & 6.3 \\
\hline Newspaper & 8.2 & 10.7 & 2 & 5.3 & 1.5 & 10.5 & 8.3 & 3.1 \\
\hline Posters & 0 & 6.1 & 2.9 & 5.3 & 0 & 5.3 & 3.3 & 9.4 \\
\hline Writing materials & 11.5 & 7.6 & 2.9 & 0 & 13.4 & 0 & 23.3 & 21.9 \\
\hline Internet & 4.9 & 1.5 & 0 & 0 & 0 & 0 & 3.3 & 6.3 \\
\hline Exchange visits & 34.4 & 9.2 & 11.8 & 21.1 & 9 & 15.8 & 35 & 21.9 \\
\hline Demonstrations & 6.6 & 6.9 & 5.9 & 10.5 & 3 & 10.5 & 25 & 18.8 \\
\hline Field days & 59.0 & 42.8 & 35.3 & 42.1 & 29.9 & 42. & 40 & 37.5 \\
\hline Agricultural shows & 34.4 & 33.6 & 11.8 & 15.8 & 9 & 21.1 & 8.4 & 40.6 \\
\hline Breeders' show & 13.1 & 4.6 & 0 & 15.8 & 4.5 & 0 & 3.3 & 12.5 \\
\hline
\end{tabular}


Next, the association between the percentage of farmers accessing information from VFTs with the proportion of VFTs in the site was established. The ratio of VFT to farmer per site was also calculated to give the number of farmers being attended to by one VFT. The highest percentage of farmers accessing information from VFTs was recorded in Kieni DFBA (62.5\%) (Table 13). The site had the highest proportion of VFTs (1/42). This signifies the importance of VFT numbers in enhancing access to information from trained farmers. An increase in the number of VFTs is likely to lead to an increase in contact between farmers and VFTs.

However, this is not always the case. For instance, the results show that Sot had the second highest percentage of farmers (46.7\%) accessing information from the VFTs. This is despite the site having the lowest proportion of VFTs (1/299). The correlation test revealed no association between the ratio of farmers per VFT and the percentage of farmers accessing information from VFTs per site. The study suggests that there are other factors such as activeness of the trainers or availability of other sources of information that could determine farmers' access to information from them. The relatively small sample size per site (Table 1) may also be responsible for these results. Sites with a low percentage of farmers accessing information from VFTs and low percentage of VFTs included Taragoon, Olkalou and Tanykina. Kieni site had the lowest ratio of VFT to farmer while Sot had the highest.

Table 13: Percentage of farmers accessing information from VFTs and percentage of VFTs per site

\begin{tabular}{lllcrr}
\hline Site & $\begin{array}{l}\text { Number of farmers } \\
\text { accessing } \\
\text { information from } \\
\text { VFTs }\end{array}$ & $\begin{array}{l}\text { \% of farmers } \\
\text { accessing } \\
\text { information from } \\
\text { VFTs }\end{array}$ & $\begin{array}{l}\text { Number } \\
\text { of VFTs } \\
\text { per site }\end{array}$ & $\begin{array}{l}\text { \% of } \\
\text { VFTs } \\
\text { per site }\end{array}$ & $\begin{array}{r}\text { Ratio of } \\
\text { farmers } \\
\text { to VFTs }\end{array}$ \\
\hline Kieni & 20 & 62.5 & 76 & 2.4 & 41.8 \\
Sot & 28 & 46.7 & 20 & 0.3 & 299 \\
Kapcheno & 15 & 44.2 & 58 & 1.7 & 57.8 \\
Cherang'ani & 17 & 27.9 & 143 & 2.4 & 41.3 \\
Taragoon & 3 & 15.8 & 10 & 0.5 & 197.2 \\
Olkalou & 10 & 14.9 & 38 & 0.6 & 174.6 \\
Metkei & 2 & 10.5 & 25 & 1.3 & 74.6 \\
Tanykina & 9 & 6.9 & 72 & 0.5 & 180.6 \\
\hline
\end{tabular}




\subsection{Types of livestock feed technologies accessed from various information sources}

Irrespective of the source, more than $50 \%$ of the farmers accessed information on nine different livestock feed technologies namely Napier grass, mineral supplementation, concentrates, silage making, Rhodes grass, conservation of crop residues, hay baling, feed formulation and fodder shrubs (tree lucerne (Chamaecytisus palmensis), calliandra (Calliandra calothyrsus) and trichandra (Leucaena trichandra) (Table 14). Overall, less than $10 \%$ of the farmers had access to information on Columbus grass, Giant setaria, purple vetch, lablab and lupine. This could be partly because of lack of awareness. Male farmers differed from women in a number of respects. A greater proportion of male farmers had access to information on lucerne, desmodium, silage making and fodder shrubs than female farmers. It could be male farmers had more time than their female counterparts to visit farmers/ demonstrations on these modern feed technologies. For other species and feeds, roughly the same percentage of women and men had accessed information.

Table 14: Types of livestock feed technologies accessed from all sources by gender

\begin{tabular}{|c|c|c|c|}
\hline Type of livestock feed technology & $\%$ male $(n=233)$ & $\%$ female $(n=190)$ & $\%$ total $(n=423)$ \\
\hline \multicolumn{4}{|l|}{ Grasses } \\
\hline Napier grass & 89.7 & 86.8 & 88.4 \\
\hline Rhodes grass & 71.7 & 70.0 & 70.9 \\
\hline Columbus grass & 10.7 & 6.8 & 9.0 \\
\hline Giant setaria & 7.3 & 5.3 & 6.4 \\
\hline \multicolumn{4}{|l|}{ Herbaceous legumes } \\
\hline Lucerne & 52.4 & $35.3^{* * *}$ & 44.7 \\
\hline Desmodium & 37.3 & $29.5 *$ & 33.8 \\
\hline Lupine & 7.7 & 4.7 & 6.4 \\
\hline Purple vetch & 3.4 & 3.7 & 3.5 \\
\hline Lablab & 3.9 & 2.1 & 3.1 \\
\hline \multicolumn{4}{|l|}{ Conserved feeds } \\
\hline Silage making & 81.5 & $70.5^{* * *}$ & 76.6 \\
\hline Conservation of crop residues & 71.2 & 68.9 & 70.2 \\
\hline Hay baling & 60.1 & 52.6 & 56.7 \\
\hline \multicolumn{4}{|l|}{ Fodder trees and shrubs } \\
\hline Fodder shrubs & 56.7 & $47.9^{*}$ & 52.7 \\
\hline Tree Lucerne & 15.9 & 16.8 & 16.3 \\
\hline \multicolumn{4}{|l|}{ Fodder grain crops } \\
\hline Sorghum & 34.3 & 35.8 & 35.0 \\
\hline Oats & 27.5 & 22.1 & 25.1 \\
\hline \multicolumn{4}{|l|}{ Root crops } \\
\hline Sweet potato vines & 45.5 & 41.1 & 43.5 \\
\hline Edible cana & 1.7 & 1.1 & 1.4 \\
\hline \multicolumn{4}{|l|}{ Other feeds } \\
\hline Mineral supplementation & 86.3 & 88.4 & 87.2 \\
\hline Concentrates & 79.4 & 80.5 & 79.9 \\
\hline Feed formulation & 55.4 & 55.8 & 55.6 \\
\hline
\end{tabular}

Women in male-headed households and female-headed households had similar access to livestock feed information except on a few practices. For instance, as seen in Table 15, women in male-headed households had significantly more access to information on Rhodes grass, conservation of crop residues and feed formulation compared to those in femaleheaded households. 
Table 15: Types of livestock feed technologies accessed from all sources by women

\begin{tabular}{|c|c|c|}
\hline $\begin{array}{l}\text { Type of livestock feed } \\
\text { technology }\end{array}$ & $\begin{array}{l}\% \text { female-headed } \\
\text { households }(n=39)\end{array}$ & $\begin{array}{l}\text { \% female in male-headed } \\
\text { households }(n=151)\end{array}$ \\
\hline \multicolumn{3}{|l|}{ Grasses } \\
\hline Napier grass & 79.5 & 88.7 \\
\hline Rhodes grass & 56.4 & $73.5^{* *}$ \\
\hline Columbus grass & 2.6 & 7.9 \\
\hline Giant setaria & 7.7 & 4.6 \\
\hline \multicolumn{3}{|l|}{ Herbaceous legumes } \\
\hline Lucerne & 33.3 & 35.8 \\
\hline Desmodium & 35.9 & 27.8 \\
\hline Lupine & 7.7 & 4.0 \\
\hline Purple vetch & 5.1 & 3.3 \\
\hline Lablab & 5.1 & 1.3 \\
\hline \multicolumn{3}{|l|}{ Conserved feeds } \\
\hline Silage making & 64.1 & 72.2 \\
\hline Conservation of crop residues & 56.4 & $72.2^{*}$ \\
\hline Hay baling & 46.2 & 54.3 \\
\hline \multicolumn{3}{|l|}{ Fodder trees and shrubs } \\
\hline Fodder shrubs & 41.0 & 49.7 \\
\hline Tree Lucerne & 20.5 & 15.9 \\
\hline \multicolumn{3}{|l|}{ Fodder grain crops } \\
\hline Sorghum & 43.6 & 33.8 \\
\hline Oats & 20.5 & 22.5 \\
\hline \multicolumn{3}{|l|}{ Root crops } \\
\hline Sweet potato vines & 35.9 & 42.4 \\
\hline Edible cana & 2.6 & 0.7 \\
\hline \multicolumn{3}{|l|}{ Other feeds } \\
\hline Mineral supplementation & 84.6 & 89.4 \\
\hline Concentrates & 66.7 & 84.1 \\
\hline Feed formulation & 41.0 & $59.6^{* *}$ \\
\hline
\end{tabular}


The percentages of farmers who accessed information on various livestock feed technologies from different sources are illustrated in Table 16 below. Information on mineral supplementation and concentrates was mainly accessed through radio. Other sources such as CESPs, field days and MoALFD were helpful to farmers accessing information on Napier grass, Rhodes grass, silage making, conservation of crop residues and fodder shrubs. From this it's deduced that farmers prefer accessing information on familiar practices from radio while information on new practices is accessed largely from interpersonal sources. Trainings offered through CESPs, field days and MoALFD are in most instances accompanied with practical sessions which probably support farmers learning on modern technologies.

In addition, the table shows important technologies for each source. For instance, Napier grass, Rhodes grass and silage were the most important technologies for MoALFD, CESPs and field days. For VFTs, their main technologies were Napier grass, Rhodes grass, conservation of crop residues and mineral supplementation. Radios had concentrates, mineral supplementation and Napier as their three key technologies. 
Table 16: Farmers' access to livestock feed technologies from different sources

\begin{tabular}{|c|c|c|c|c|c|c|c|c|c|c|c|c|c|c|c|c|c|c|c|c|}
\hline Feed technology & MoA & NGO & FO & KARI & VFTs & CESPs & SF & Neighb & ID & PSP & MP & Radio & TV & NP & WM & Int & $\mathbf{E X}$ & Demo & FD & ASK \\
\hline \multicolumn{21}{|l|}{ Grasses } \\
\hline Napier grass & 26.0 & 2.8 & 7.8 & 3.5 & 16.3 & 28.1 & 7.3 & 15.4 & 0.9 & 3.8 & 1.4 & 17.3 & 4.7 & 2.1 & 6.1 & 0 & 9.7 & 3.8 & 22.7 & 9.5 \\
\hline Rhodes grass & 18.2 & 1.7 & 4.7 & 2.4 & 10.9 & 21.7 & 4.5 & 11.8 & 2.1 & 3.1 & 0.9 & 10.9 & 1.4 & 1.4 & 5.2 & 0 & 8.0 & 3.1 & 20.1 & 10.4 \\
\hline Columbus & 0.9 & 0 & 0.7 & 0.5 & 0.9 & 2.4 & 0.7 & 0.7 & 0.7 & 0 & 0 & 0.7 & 0.2 & 0 & 0 & 0 & 0.5 & 0.2 & 1.7 & 0.5 \\
\hline Giant setaria & 0.7 & 0.5 & 0 & 0.5 & 0.9 & 0.5 & 0.5 & 0 & 0 & 0.5 & 0 & 0.5 & 0.5 & 0.2 & 0.7 & 0.2 & 1.4 & 0.2 & 0 & 0.7 \\
\hline \multicolumn{21}{|c|}{ Herbaceous legumes } \\
\hline Lucerne & 10.2 & 1.9 & 2.1 & 2.8 & 5.4 & 18.2 & 1.7 & 3.5 & 0.7 & 0.5 & 0 & 4.5 & 0.7 & 0.2 & 3.3 & 0.5 & 4.0 & 2.4 & 5.2 & 5.0 \\
\hline Desmodium & 4.5 & 1.2 & 2.4 & 1.7 & 3.8 & 10.6 & 1.7 & 1.9 & 0.9 & 0.5 & 0.2 & 5.4 & 0 & 0.9 & 1.4 & 0.2 & 2.1 & 2.1 & 8.0 & 3.1 \\
\hline Lupine & 0.5 & 0.9 & 0.7 & 0.5 & 1.2 & 0.7 & 0.2 & 0.7 & 0.2 & 0.2 & 0 & 0.5 & 0.2 & 0 & 1.2 & 0 & 0.5 & 0.2 & 0 & 1.2 \\
\hline Purple vetch & 0 & 0.5 & 0 & 0.2 & 0 & 0.2 & 0 & 0.5 & 0 & 0 & 0 & 0.7 & 0 & 0 & 0.2 & 0.2 & 0.2 & 0.7 & 0 & 0.2 \\
\hline Lablab & 0 & 0.2 & 0.2 & 0 & 0.2 & 1.2 & 0 & 0.5 & 0 & 0 & 0 & 0 & 0 & 0 & 0.2 & 0 & 0.5 & 0 & 0 & 0.2 \\
\hline \multicolumn{21}{|l|}{ Conserved feeds } \\
\hline Conservation & 15.8 & 4.5 & 6.1 & 1.2 & 11.3 & 18.9 & 4.3 & 11.1 & 0.9 & 2.6 & 0.5 & 11.3 & 4.0 & 2.4 & 5.7 & 0.9 & 6.4 & 2.1 & 16.1 & 8.3 \\
\hline Silage & 16.1 & 4.7 & 5.4 & 1.7 & 9.7 & 21.5 & 4.7 & 10.4 & 0.5 & 1.9 & 0.9 & 10.2 & 5.4 & 1.7 & 6.6 & 0.9 & 8.3 & 6.1 & 20.8 & 11.6 \\
\hline Hay & 11.3 & 3.3 & 3.5 & 1.4 & 8.0 & 18.2 & 3.8 & 4.7 & 0.7 & 1.2 & 0 & 6.9 & 2.8 & 1.4 & 4.3 & 0.5 & 6.9 & 3.3 & 15.8 & 10.6 \\
\hline \multicolumn{21}{|c|}{ Fodder trees/shrubs } \\
\hline Fodder shrubs & 14.9 & 6.1 & 3.1 & 2.1 & 9.9 & 17.5 & 2.8 & 2.6 & 0 & 1.7 & 0.5 & 5.2 & 1.4 & 0.7 & 5.0 & 0.5 & 4.5 & 1.7 & 11.1 & 4.0 \\
\hline Tree Lucerne & 2.6 & 1.9 & 0.7 & 1.4 & 1.7 & 3.5 & 0.7 & 0.9 & 0 & 0.7 & 0.2 & 0.9 & 0.7 & 0 & 0.5 & 0 & 1.4 & 0.2 & 6.6 & 1.7 \\
\hline \multicolumn{21}{|c|}{ Fodder grain crops } \\
\hline Sorghum & 7.3 & 1.2 & 2.4 & 1.9 & 5.4 & 12.1 & 1.4 & 2.8 & 0.9 & 1.2 & 0.2 & 3.3 & 0 & 0.7 & 2.1 & 0.2 & 3.1 & 1.7 & 3.5 & 3.5 \\
\hline Oats & 4.3 & 0.5 & 2.1 & 1.4 & 2.4 & 4.0 & 2.4 & 2.6 & 0.2 & 0.2 & 0.2 & 2.6 & 0.7 & 0.2 & 0.9 & 0 & 1.4 & 1.4 & 3.3 & 1.7 \\
\hline \multicolumn{21}{|l|}{ Root crops } \\
\hline S.P vines & 8.7 & 1.4 & 2.8 & 1.7 & 5.9 & 8.0 & 1.7 & 7.8 & 0.7 & 2.1 & 1.4 & 7.1 & 1.9 & 1.9 & 1.7 & 1.4 & 4.7 & 1.2 & 7.3 & 2.8 \\
\hline Edible cana & 0 & 0 & 0 & 0 & 0 & 0 & 0 & 0.2 & 0.2 & 0 & 0 & 0 & 0 & 0 & 0 & 0.2 & 0 & 0 & 0.2 & 0 \\
\hline \multicolumn{21}{|l|}{ Other feeds } \\
\hline Mineral & 11.8 & 2.6 & 4.0 & 1.2 & 10.9 & 15.4 & 4.7 & 10.4 & 12.8 & 5.0 & 1.7 & 32.6 & 5.9 & 4.0 & 5.0 & 1.7 & 6.4 & 1.9 & 19.6 & 9.7 \\
\hline Concentrates & 9.9 & 3.5 & 4.0 & 2.1 & 7.8 & 14.7 & 5.0 & 8.7 & 11.8 & 4.5 & 1.9 & 25.5 & 4.7 & 2.8 & 5.2 & 1.4 & 4.7 & 1.4 & 17.0 & 7.8 \\
\hline Feed form & 10.6 & 3.1 & 4.7 & 0.9 & 6.1 & 16.5 & 3.3 & 4.0 & 0.5 & 1.4 & 0.2 & 8.7 & 3.3 & 1.9 & 5.4 & 0.5 & 5.4 & 2.4 & 11.3 & 8.3 \\
\hline
\end{tabular}

Abbreviations: MoA (Ministry of Agriculture, Livestock and Fisheries Development), NGO (Non-Governmental Organization), FO (Farmer Organizations), SF (Skilled Farmers), Neighb

(Neigbours), ID (Input Dealers), PSP (Private Service Providers), MP (Mobile Phone), TV (Television), NP (Newspapers), WM (Written Materials), Int (Internet), EV (Exchange Visits), Demo (Demonstrations), FD (Field Days), ASK (Agricultural Shows of Kenya) 


\subsection{Preferred sources of information}

Results in Table 17 show how farmers scored various information sources as high-, mediumor low-preference sources. The total score and overall rank show preference in terms of quality and extent of use of different sources. The average score presented in the table shows the average preference of those farmers rating a particular source. Considering the total scores and overall rank, CESPs were the most preferred source of information by the sampled farmers, who largely depend on them to access information on livestock feeds. CESPs provide opportunities for face-to-face communication and respond to farmers' questions almost immediately. Radio and MoALFD were ranked the $2^{\text {nd }}$ and $3^{\text {rd }}$ most preferred sources respectively. Neighbours, farmer cooperatives, field days, VFTs, input dealers and agricultural shows were also ranked among the top 10 preferred sources.

The average score for sources used by more than 20 farmers show that CESPs received the highest average score of 2.34 out of 3 , followed by MoAFLD staff and field days. VFTs ranked $10^{\text {th }}$ on average score among the 13 sources used by more than 20 farmers, indicating that while some farmers found them useful, others did not. Among sources used by more than 20 farmers, those with the lowest scores were exchange visits, farmer cooperatives and skilled farmers. The low scores for skilled farmers and exchange visits may indicate that the farmers visited are at too high a level to provide information that is useful for the visiting farmers. Differentiating by gender, Table 18 reveals that female farmers who used CESPs rated them about the same as male farmers (average scores of 2.36 vs. 2.32, respectively). Both male and female farmers had CESPs and radio as their $1^{\text {st }}$ and $2^{\text {nd }}$ preferred sources of information, respectively. Differences however emerged in the third preference of information source with male farmers preferring MoALFD and female farmers preferring neighbours. Relative to other sources, the VFTs were ranked $7^{\text {th }}$ by male farmers and $8^{\text {th }}$ by female farmers.

Differences between males and females in preferences were significant for only three of the 23 sources. Women had lower preferences for field days and agricultural shows than men, perhaps because these often involve travelling away from the farm for an extended period. Men had less preference for input dealers than women, though the difference was only marginally significant $(\mathrm{P}<0.10)$.

Farmers' preference for information sources varied across sites as presented in Table 19. Radio, CESPs and MoALFD formed the most preferred sources of information in all the sites. The table further shows that CESPs were mostly preferred in Sot, Cherang'ani and Tanykina. MoALFD was preferred in Cherang'ani, Sot and Kieni while radio was mostly preferred by farmers in Tanykina, Olkalou and Kapcheno sites. VFTs received relatively low scores in Metkei, Taragoon and Tanykina. 
Table 17: Farmers preferences among different sources of information

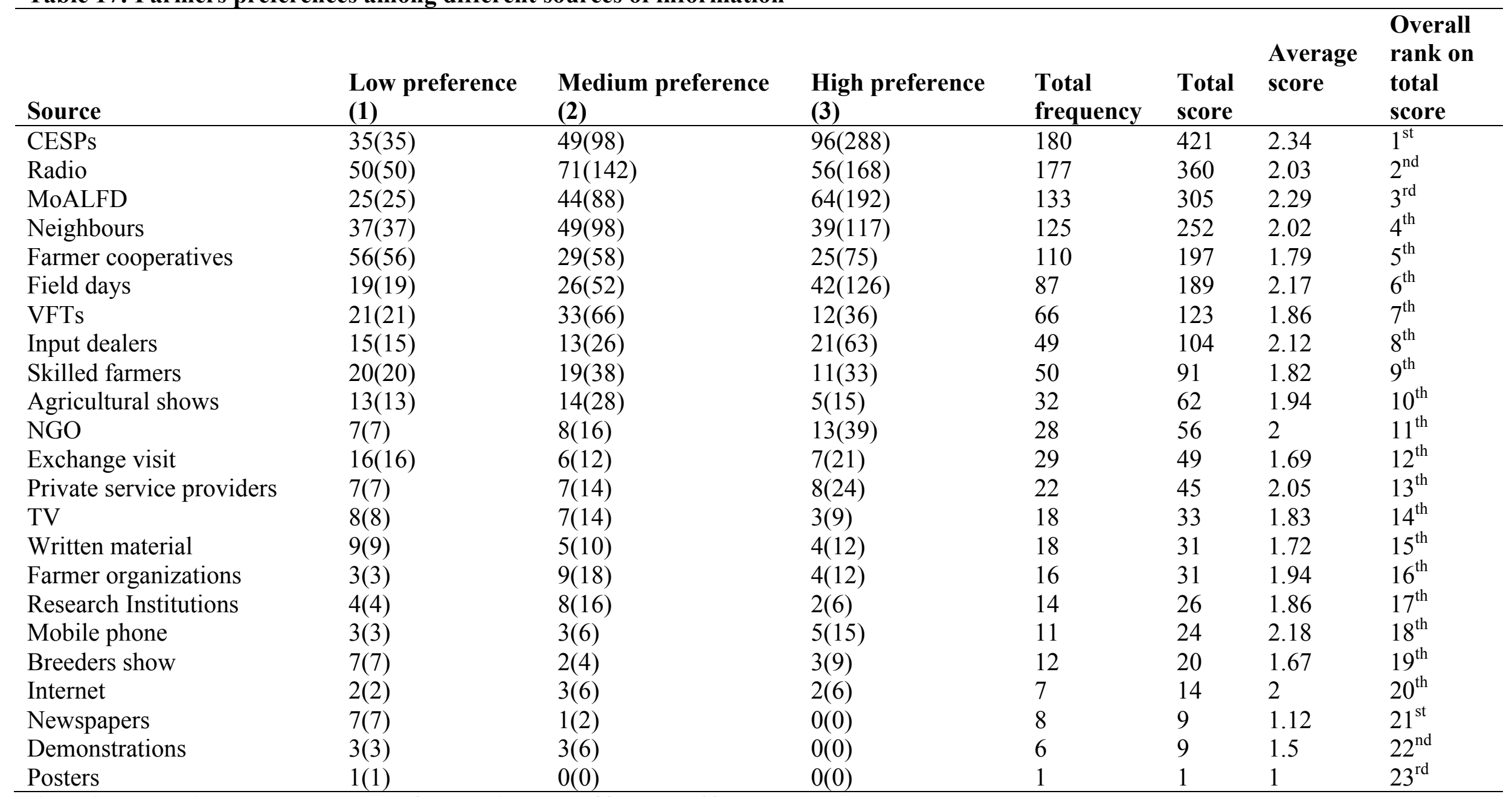

Figures in parenthesis present the scores; Total frequency is the sum of frequency of farmers who rated the sources 
Table 18: Preferred sources of information by gender

\begin{tabular}{|c|c|c|c|c|c|c|c|c|}
\hline \multirow{3}{*}{ Source } & \multicolumn{4}{|c|}{ Male farmers } & \multicolumn{4}{|c|}{ Female farmers } \\
\hline & & & & & & & & Overall \\
\hline & $\begin{array}{l}\text { Total } \\
\text { frequency }\end{array}$ & $\begin{array}{l}\text { Total } \\
\text { score }\end{array}$ & $\begin{array}{l}\text { Average } \\
\text { score }\end{array}$ & $\begin{array}{l}\text { Overall } \\
\text { rank }\end{array}$ & $\begin{array}{l}\text { Total } \\
\text { frequency }\end{array}$ & $\begin{array}{l}\text { Total } \\
\text { score }\end{array}$ & $\begin{array}{l}\text { Average } \\
\text { score }\end{array}$ & $\begin{array}{l}\text { rank on } \\
\text { total score }\end{array}$ \\
\hline CESPs & 93 & 216 & 2.32 & 1 & 87 & 205 & 2.36 & 1 \\
\hline Radio & 96 & 195 & 2.03 & 2 & 81 & 165 & 2.04 & 2 \\
\hline MoALFD & 75 & 179 & 2.39 & 3 & 54 & 116 & 2.15 & 4 \\
\hline Field days & 75 & 137 & 1.83 & 4 & $28 * * *$ & 52 & 1.86 & 7 \\
\hline Neighbours & 64 & 124 & 1.94 & 5 & 61 & 128 & 2.1 & 3 \\
\hline Farmer cooperatives & 45 & 98 & 2.18 & 6 & 42 & 99 & 2.36 & 5 \\
\hline VFTs & 39 & 73 & 1.87 & 7 & 27 & 50 & 1.85 & 8 \\
\hline Skilled farmers & 29 & 52 & 1.79 & 8 & 21 & 39 & 1.86 & 9 \\
\hline Agricultural shows & 24 & 45 & 1.88 & 9 & $8 * *$ & 12 & 1.5 & 16 \\
\hline Input dealers & 21 & 44 & 2.1 & 10 & $35^{*}$ & 59 & 1.69 & 6 \\
\hline Exchange visit & 16 & 29 & 1.81 & 11 & 13 & 22 & 1.69 & 12 \\
\hline $\mathrm{NGO}$ & 15 & 27 & 1.8 & 12 & 13 & 33 & 2.54 & 10 \\
\hline Private service providers & 10 & 20 & 2 & 13 & 12 & 25 & 2.08 & 11 \\
\hline TV & 10 & 19 & 1.9 & 14 & 8 & 12 & 1.5 & 17 \\
\hline Written material & 10 & 18 & 1.8 & 15 & 8 & 13 & 1.63 & 14 \\
\hline Farmer organizations & 8 & 16 & 2 & 16 & 8 & 17 & 2.13 & 13 \\
\hline Breeders show & 9 & 13 & 1.44 & 17 & 3 & 7 & 2.33 & 19 \\
\hline Research Institutions & 6 & 13 & 2.17 & 18 & 8 & 13 & 1.63 & 15 \\
\hline Mobile phone & 5 & 12 & 2.4 & 19 & 6 & 12 & 2 & 18 \\
\hline Internet & 5 & 8 & 1.6 & 20 & 2 & 6 & 3 & 20 \\
\hline Demonstrations & 5 & 8 & 1.6 & 21 & 1 & 1 & 1 & 22 \\
\hline Newspapers & 5 & 6 & 1.2 & 22 & 3 & 3 & 1 & 21 \\
\hline Posters & 1 & 1 & 1 & 23 & 0 & 0 & 0 & 23 \\
\hline
\end{tabular}

Total score is the sum of scores for each preference. Scores were got by multiplying frequencies on each preference level by scores assigned where low preference was given a score of

1 , medium a score of 2 and high a score of 3 . Asterisks indicate significant differences between men and women in total frequency $\left(* * * p<0.01,{ }^{* *} p<0.05,{ }^{*} p<0.1\right)$. 
Table 19: Farmers ranking on preferred sources of information by site

\begin{tabular}{|c|c|c|c|c|c|c|c|c|}
\hline & $\begin{array}{l}\text { Cherang'ani }(\mathbf{N}=\mathbf{6 1} \text { ) } \\
\text { Total frequency } \\
\text { (Total score) }\end{array}$ & $\begin{array}{l}\text { Tanykina }(\mathbf{N}=\mathbf{1 3 1}) \\
\text { Total frequency } \\
\text { (Total score) }\end{array}$ & $\begin{array}{l}\text { Kapcheno }(\mathbf{N}=\mathbf{3 4}) \\
\text { Total frequency } \\
\text { (Total score) }\end{array}$ & $\begin{array}{l}\text { Metkei }(\mathbf{N}=\mathbf{1 9}) \\
\text { Total frequency } \\
\text { (Total score) }\end{array}$ & $\begin{array}{l}\text { Olkalou ( } \mathbf{N}=\mathbf{6 7} \text { ) } \\
\text { Total frequency } \\
\text { (Total score) }\end{array}$ & $\begin{array}{l}\text { Taragoon }(\mathbf{N}=\mathbf{1 9}) \\
\text { Total frequency } \\
\text { (Total score) }\end{array}$ & $\begin{array}{l}\text { Sot }(\mathbf{N}=\mathbf{6 0}) \\
\text { Total } \\
\text { frequency } \\
\text { (Total score) }\end{array}$ & $\begin{array}{l}\text { Kieni }(\mathbf{N}=\mathbf{3 2}) \\
\text { Total } \\
\text { frequency } \\
\text { (Total score) }\end{array}$ \\
\hline CESPs & $(41) 99^{*}$ & $(27) 68$ & (11)21 & (11)24 & (19)41 & (5) 14 & $(52) 132$ & (14)22 \\
\hline MoALFD & $(32) 83$ & (10)21 & (8)16 & (5) 15 & (13)36 & (8) 15 & $(31) 58$ & $(22) 59$ \\
\hline Field days & $(25) 41$ & $(45) 81$ & (11)18 & (9) 17 & (10)16 & (5) 10 & (3) 4 & (2) 2 \\
\hline Neighbours & $(15) 21$ & (67)143 & $(15) 38$ & (5)11 & (14)22 & (1) 1 & $(5) 9$ & (3) 7 \\
\hline VFTs & (12)24 & (3) 6 & (8)11 & $(0) 0$ & (11) 23 & (1) 1 & (19)33 & (12)22 \\
\hline $\begin{array}{l}\text { Skilled farmers } \\
\text { Farmer }\end{array}$ & (12)17 & (12)21 & (4) 10 & (3) 5 & (13) 25 & (4)9 & $(2) 4$ & $(0) 0$ \\
\hline cooperatives & (6) 15 & $(40) 93$ & $(0) 0$ & (3) 7 & (13) 26 & (2) 2 & (12)30 & (11)24 \\
\hline Radio & (7) 12 & (70)158 & $(22) 44$ & (8) 15 & $(28) 63$ & (6)14 & $(26) 37$ & (10)17 \\
\hline $\begin{array}{l}\text { Exchange visit } \\
\text { Research }\end{array}$ & (7)9 & $(10) 17$ & (1) 1 & (1)3 & (2) 5 & (2) 5 & $(5) 6$ & (1)3 \\
\hline $\begin{array}{l}\text { Institutions } \\
\text { Agricultural } \\
\text { shows }\end{array}$ & $\begin{array}{l}(10) 7 \\
(4) 7\end{array}$ & $\begin{array}{l}(0) 0 \\
(19) 31\end{array}$ & $\begin{array}{l}(0) 0 \\
(1) 2\end{array}$ & $\begin{array}{l}(1) 2 \\
(1) 2\end{array}$ & $\begin{array}{l}(3) 7 \\
(3) 7\end{array}$ & $\begin{array}{l}(0) 0 \\
(2) 5\end{array}$ & $\begin{array}{l}(0) 0 \\
(1) 1\end{array}$ & $\begin{array}{l}(0) 0 \\
(1) 1\end{array}$ \\
\hline Breeders show & (3)7 & $(4) 6$ & $(0) 0$ & (1) 1 & $(4) 6$ & $(0) 0$ & $(0) 0$ & $(0) 0$ \\
\hline NGO & $(2) 3$ & $(0) 1$ & (13)33 & $(0) 0$ & (5) 11 & $(0) 0$ & (4) 9 & (4)6 \\
\hline $\begin{array}{l}\text { Internet } \\
\text { Private service } \\
\text { providers }\end{array}$ & $\begin{array}{l}(2) 3 \\
(2) 2\end{array}$ & $\begin{array}{l}(1) 3 \\
(2) 2\end{array}$ & $\begin{array}{l}(0) 0 \\
(0) 0\end{array}$ & $\begin{array}{l}(0) 0 \\
(0) 0\end{array}$ & $\begin{array}{l}(2) 4 \\
(5) 10\end{array}$ & $\begin{array}{l}(0) 0 \\
(3) 5\end{array}$ & $\begin{array}{l}(0) 0 \\
(8) 21\end{array}$ & $\begin{array}{l}(0) 0 \\
(2) 5\end{array}$ \\
\hline Written material & $(1) 3$ & $(5) 8$ & (1) 1 & $(0) 0$ & $(5) 11$ & $(0) 0$ & $(2) 4$ & (1) 2 \\
\hline $\begin{array}{l}\text { Input dealers } \\
\text { Farmer } \\
\text { organizations }\end{array}$ & $\begin{array}{l}(1) 2 \\
(0) 0\end{array}$ & $\begin{array}{l}(16) 33 \\
(3) 6\end{array}$ & $\begin{array}{l}(1) 1 \\
(0) 0\end{array}$ & $\begin{array}{l}(0) 0 \\
(0) 0\end{array}$ & $\begin{array}{l}(24) 54 \\
(3) 6\end{array}$ & $\begin{array}{l}(3) 8 \\
(4) 10\end{array}$ & $\begin{array}{l}(2) 2 \\
(4) 7\end{array}$ & $\begin{array}{l}(2) 4 \\
(2) 4\end{array}$ \\
\hline $\mathrm{TV}$ & $(0) 0$ & (10)20 & (3) 3 & (1) 1 & (3) 5 & (1) 2 & $(0) 0$ & $(0) 0$ \\
\hline Mobile phone & $(0) 0$ & (7) 18 & $(0) 0$ & (1) 2 & (3) 4 & $(0) 0$ & $(0) 0$ & $(0) 0$ \\
\hline Newspapers & $(0) 0$ & (2) 2 & $(0) 0$ & $(0) 0$ & (1) 1 & $(0) 0$ & $(0) 0$ & $(0) 0$ \\
\hline Demonstrations & $(0) 0$ & (2) 4 & $(0) 0$ & $(0) 0$ & (3) 4 & (1) 1 & $(0) 0$ & $(0) 0$ \\
\hline Posters & $0(0)$ & $0(0)$ & $0(0)$ & $0(0)$ & $0(0)$ & $0(0)$ & $0(0)$ & $0(0)$ \\
\hline
\end{tabular}

*The highest score indicates the highest rank. Calculation of scores is explained in the note to Table 18. 


\subsubsection{Frequency of use, reliability, accessibility and affordability of preferred sources of information compared to the VFTs}

The reliability, frequency of contact, accessibility and affordability of the three most preferred sources of information and the VFTs were determined. Farmers scored the aspects on a scale of 1 to 5 where 5 was highest and 1 was lowest. The mean score was then calculated to determine farmers' perception of the extent of reliability, frequency of contact, accessibility and affordability of the sources. The results are as presented in Table 20. CESPs had high average scores on reliability and affordability. CESPs, MoALFD and VFTs all scored highly on reliability of their information. VFTs and CESPs scored highest on frequency of use, reflecting their close physical location to farmers. MoALFD on the other hand scored low on frequency of contact. Radio, VFTs and CESPs scored highly on accessibility and affordability as compared to MoAFLD. Against the four criteria, CESPs and VFTs achieved the highest scores. The scores on reliability, frequency, accessibility and affordability of VFTs (Table 20), which are very high, appear to be somewhat inconsistent with VFT's average preference scores, which are somewhat lower (Table 18). Even though VFTs are viewed as reliable, accessible and affordable, according to Table 20, they advise on fewer topics than do the other sources and that may explain their low score on preference.

Table 20: Mean scores on reliability, frequency, accessibility and affordability of preferred sources of information compared to the VFTs

\begin{tabular}{|c|c|c|c|c|c|c|}
\hline Source & $\mathbf{N}$ & Reliability & $\begin{array}{l}\text { Frequenc } \\
\mathbf{y}\end{array}$ & $\begin{array}{l}\text { Accessibilit } \\
\mathbf{y}\end{array}$ & $\begin{array}{l}\text { Affordabilit } \\
y\end{array}$ & $\begin{array}{l}\text { Overall } \\
\text { mean score }\end{array}$ \\
\hline CESPs & 180 & $4.6^{\mathrm{a}}$ & 4.1 & 4.4 & 4.6 & 4.4 \\
\hline Radio & 177 & 4.0 & 3.7 & 4.5 & 4.6 & 4.2 \\
\hline MoALFD & 133 & 4.5 & 2.9 & 3.4 & 3.6 & 3.6 \\
\hline VFTs & 66 & 4.5 & 4.2 & 4.5 & 4.5 & 4.4 \\
\hline
\end{tabular}

${ }^{\mathrm{a}} 5=$ =highly, $4=$ high, $3=$ moderate, $2=$ =low, 1=lowest

The reliability, frequency, accessibility and affordability of preferred sources were examined by gender (Table 21). Both male and female farmers awarded almost similar scores to CESPs and radio in terms of their reliability, frequency, accessibility and affordability. Male farmers considered MoALFD to be highly reliable but not very easy to contact, access and afford. Female farmers scored their neighbours highly in all aspects. Overall, CESPs had the highest score among male farmers, while neighbours took the lead among female farmers. There were no significant differences in reliability, frequency, accessibility and affordability of preferred sources between male and female farmers. 
Table 21: Reliability, frequency, accessibility and affordability of preferred sources of information and VFTs by gender

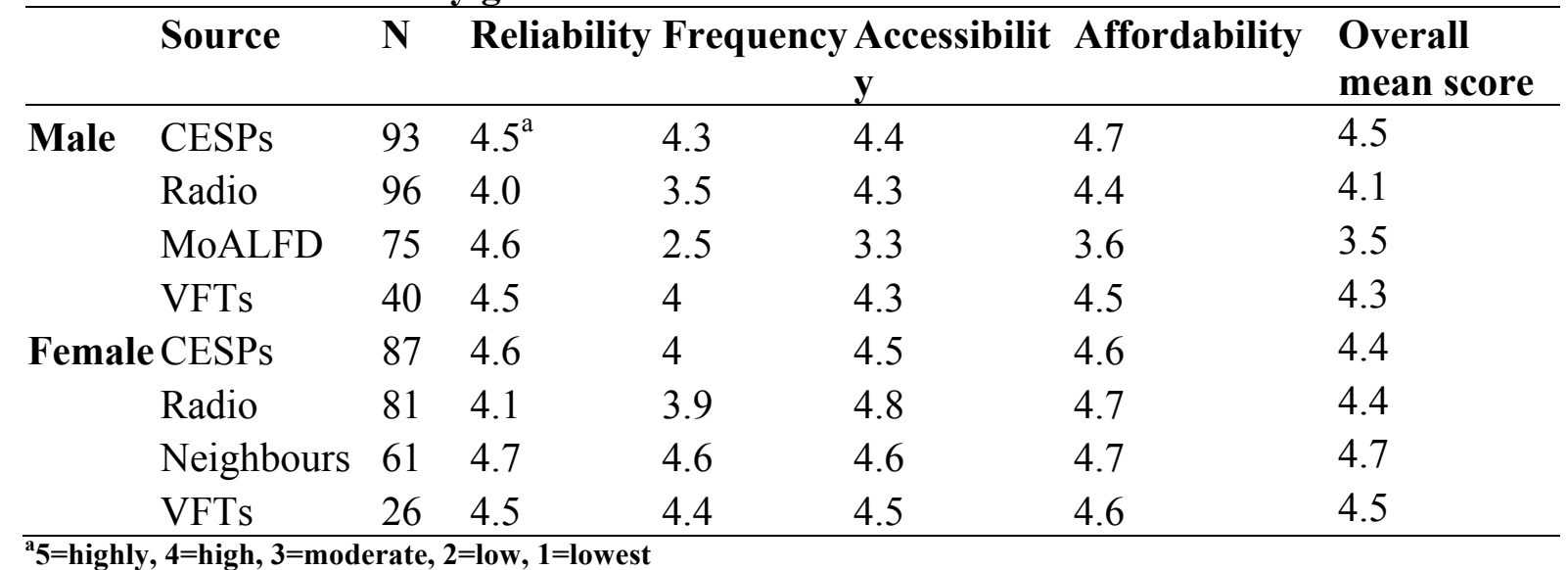

\subsection{Training on livestock feed technologies}

Table 22 present the results of the persons trained in the household. Farmers were asked to state if any member of the household had ever received training on livestock feed technologies from any source. About $60 \%$ of farmers trained were household heads and $25.2 \%$ were spouses. Attendance of trainings by the household heads is useful in improving their farm practices. Occasionally, some farmers do let their workers attend training workshops, especially in households where the head and spouse are frequently absent.

Table 22: Household members who have ever received training from any source

\begin{tabular}{lll}
\hline Person Trained & N & Percentage \\
\hline Head & 270 & 60 \\
Spouse & 113 & 25.2 \\
Farm worker & 9 & 2 \\
Son & 10 & 2.2 \\
None & 47 & 10.5 \\
Total (N) & $\mathbf{4 4 9}$ & $\mathbf{1 0 0}$ \\
\hline
\end{tabular}

About $88.9 \%$ of the farmers had been trained on livestock feed technologies. Of the male farmers, $90.1 \%$ were trained, while of the female farmers, $87.4 \%$ were trained. More than $50 \%$ of trained farmers reported to have been trained on Napier grass, silage making, Rhodes grass, mineral supplementation, conservation of crop residues and concentrates (Table 23). Significant differences in percentages of farmers trained were recorded in only two technologies, that is, lucerne and desmodium. However, results show that women received training in similar technologies as men but at slightly lower rates, except for mineral 
supplementation. Overall, less than $10 \%$ of farmers had been trained on tree Lucerne and Columbus grass.

Table 23: Training on livestock feed technologies by gender

\begin{tabular}{|c|c|c|c|}
\hline Feed technology & $\%$ male $(\mathrm{N}=210)$ & $\%$ female $(\mathrm{N}=166)$ & $\%$ total $(\mathrm{N}=376)$ \\
\hline \multicolumn{4}{|l|}{ Grasses } \\
\hline Napier grass & 79.0 & 74.7 & 77.1 \\
\hline Rhodes grass & 59.7 & 55.8 & 57.9 \\
\hline Columbus grass & 5.6 & 3.7 & 4.7 \\
\hline Giant setaria & 4.3 & 2.6 & 3.5 \\
\hline \multicolumn{4}{|l|}{ Herbaceous legumes } \\
\hline Lucerne & 36.9 & $26.3 * *$ & 32.2 \\
\hline Desmodium & 24.0 & $16.3^{*}$ & 20.6 \\
\hline Lupine & 4.7 & 2.6 & 3.8 \\
\hline Purple vetch & 1.3 & 1.6 & 1.4 \\
\hline Lablab & 1.3 & 1.1 & 1.2 \\
\hline \multicolumn{4}{|l|}{ Conserved feeds } \\
\hline Silage making & 63.5 & 58.4 & 61.2 \\
\hline Conservation of crop residues & 54.1 & 51.6 & 53.0 \\
\hline Hay baling & 41.6 & 37.9 & 40.0 \\
\hline \multicolumn{4}{|l|}{ Fodder trees and shrubs } \\
\hline Fodder shrubs & 45.5 & 46.3 & 45.9 \\
\hline Tree Lucerne & 7.7 & 10.0 & 8.7 \\
\hline \multicolumn{4}{|l|}{ Other fodder crops } \\
\hline Sweet potato vines & 30.0 & 29.5 & 29.8 \\
\hline Sorghum & 26.2 & 22.6 & 24.6 \\
\hline Oats & 18.0 & 13.2 & 15.8 \\
\hline Mulberry & 3.0 & 2.1 & 2.6 \\
\hline Edible cana & 1.7 & 1.6 & 1.7 \\
\hline \multicolumn{4}{|l|}{ Other feeds } \\
\hline Mineral supplementation & 53.6 & 58.9 & 56.0 \\
\hline Concentrates & 51.9 & 47.9 & 50.1 \\
\hline Feed formulation & 37.3 & 36.8 & 37.1 \\
\hline
\end{tabular}

$* * * p<0.01, * * p<0.05, * p<0.1$

Further analysis however shows that $92.1 \%$ of women in male-headed household received training whereas $69.2 \%$ of women in female-headed households did. The difference was highly significant $(\mathrm{p}<0.01)$. Whereas, male and female farmers received training in about equal measure, women in female-headed households received far less training than men and women in male-headed households (Table 24). A significantly higher percentage of women in male-headed households received training on conservation of crop residues and oats than women in male-headed households. 
Table 24: Disparities in training on livestock feed technologies between women in maleheaded households and women in female-headed households

\begin{tabular}{|c|c|c|}
\hline Type of technology & $\begin{array}{l}\text { \% women in female-headed } \\
\text { households }(\mathrm{N}=27)\end{array}$ & $\begin{array}{l}\text { \% female in male } \\
\text { headed households }(\mathrm{N}=139)\end{array}$ \\
\hline \multicolumn{3}{|l|}{ Grasses } \\
\hline Napier grass & 77.8 & 70.5 \\
\hline Rhodes grass & 48.1 & 46.8 \\
\hline Columbus grass & 3.7 & 0.7 \\
\hline Giant setaria & 3.7 & 0.7 \\
\hline \multicolumn{3}{|l|}{ Herbaceous legumes } \\
\hline Lucerne & 22.2 & 16.5 \\
\hline Desmodium & 22.2 & 9.4 \\
\hline Purple vetch & 0.0 & 1.4 \\
\hline Lablab & 0.0 & 0.7 \\
\hline Lupine & 0.0 & 0.7 \\
\hline \multicolumn{3}{|l|}{ Conserved feeds } \\
\hline Silage making & 55.6 & 45.3 \\
\hline Conservation of crop residues & 33.3 & $45.3^{*}$ \\
\hline Hay baling & 22.2 & 30.9 \\
\hline \multicolumn{3}{|l|}{ Fodder trees and shrubs } \\
\hline Fodder shrubs & 48.1 & 33.1 \\
\hline Tree Lucerne & 3.7 & 7.2 \\
\hline \multicolumn{3}{|l|}{ Other fodder crops } \\
\hline Sweet potato vines & 14.8 & 18.7 \\
\hline Sorghum & 22.2 & 17.3 \\
\hline Oats & 11.1 & $6.5^{*}$ \\
\hline Mulberry & 3.7 & 0.0 \\
\hline \multicolumn{3}{|l|}{ Other feeds } \\
\hline Mineral supplementation & 37.0 & 39.6 \\
\hline Concentrates & 37.0 & 32.4 \\
\hline Feed formulation & 37.0 & 26.6 \\
\hline
\end{tabular}

Farmers from all sites received training in most livestock feed technologies. Napier grass appeared to be the technology with the highest proportion of farmers trained, except in Taragoon where it came second after silage making (Table 25). Unlike other sites, most farmers in Metkei and Olkalou stated that they had been trained on oats because it is one of the major livestock feeds used in the areas. Generally, farmers in all sites reported not having been trained on at least two technologies. This is logical as some technologies are not relevant in some agro-ecological zones.

In the present study, farmers received training from several sources: CESPs (56.7\%), neighbours (46.3\%), MoAFLD (38.1\%), input dealers (18.9\%), self-experience (17\%), VFTs (10.9\%), NGO (10.1\%), FTC (9.9\%), KARI (6.4\%) and ASK (3.1\%). Overall, most trainings 
were on Napier grass, Rhodes grass, mineral supplementation, concentrates, silage making, conservation of crop residues and fodder shrubs (Table 26). Different institutions emphasized different topics in their training. CESPs, MoALFD and neighbours featured as the most dominant institutions offering training on Napier grass. Others like NGOs put emphasis on fodder shrubs and sorghum.

The study sought to understand the frequency of training by institutions in the past six months. Frequencies were captured in six aspects. "Not so often" referred to institutions that offered few training sessions, that is, once to three times in the past six months while "very often" referred to institutions that conducted training at least every week. Asked about how many times they had been trained in the past six months, sources that emerged top in training farmers included CESPs, neighbours, and MoALFD staff in terms of numbers of farmers receiving training and neighbours, CESPs and VFTs in terms of frequency of training (Table 27). About $47.5 \%$ had received training very often or more than once per month from neighbours, $45.4 \%$ from CESPs and $39.1 \%$ from VFTs. Few farmers received periodic training from MoALFD and NGOs. The results coincide with earlier findings that indicated low frequency of contact between farmers and MoALFD. Non-governmental organizations on the other hand had low frequency probably because they only operated when their projects were running. Additionally, about $40 \%$ of the farmers received training once from research institutes and the ASK. 
Table 25: Percentage of farmers trained on livestock feed technologies by site

\begin{tabular}{|c|c|c|c|c|c|c|c|c|}
\hline Feed Technology & $\begin{array}{l}\text { Cherang'ani } \\
(\mathrm{N}=61)\end{array}$ & $\begin{array}{l}\text { Tanykina } \\
(\mathrm{N}=131)\end{array}$ & $\begin{array}{l}\text { Kapcheno } \\
(\mathrm{N}=34)\end{array}$ & $\begin{array}{l}\text { Metkei } \\
(\mathrm{N}=19)\end{array}$ & $\begin{array}{l}\text { Olkalou } \\
(\mathrm{N}=67)\end{array}$ & $\begin{array}{l}\text { Taragoon } \\
(\mathrm{N}=19)\end{array}$ & $\begin{array}{l}\text { Sot } \\
(\mathrm{N}=60)\end{array}$ & $\begin{array}{l}\text { Kieni } \\
(\mathbf{N}=32)\end{array}$ \\
\hline \multicolumn{9}{|l|}{ Grasses } \\
\hline Napier grass & 88.5 & 74.0 & 85.3 & 63.2 & 50.7 & 57.9 & 100 & 90.6 \\
\hline Rhodes grass & 78.7 & 66.4 & 26.5 & 42.1 & 14.9 & 42.1 & 98.3 & 50.0 \\
\hline Columbus grass & 4.9 & 6.1 & 0.0 & 5.3 & 1.5 & 15.8 & 1.7 & 9.4 \\
\hline Giant setaria & 16.4 & 0.8 & 0.0 & 0.0 & 1.5 & 5.3 & 1.7 & 3.1 \\
\hline \multicolumn{9}{|l|}{ Herbaceous legumes } \\
\hline Lucerne & 45.9 & 27.5 & 17.6 & 15.8 & 16.4 & 42.1 & 58.3 & 28.1 \\
\hline Desmodium & 34.4 & 9.9 & 2.9 & 5.3 & 6.0 & 15.8 & 63.3 & 18.8 \\
\hline Purple vetch & 0.0 & 0.0 & 0.0 & 5.3 & 4.5 & 5.3 & 0.0 & 3.1 \\
\hline Lablab & 3.3 & 0.0 & 0.0 & 0.0 & 3.0 & 0.0 & 1.7 & 0.0 \\
\hline Lupine & 13.1 & 1.5 & 0.0 & 0.0 & 3.0 & 10.5 & 1.7 & 3.1 \\
\hline \multicolumn{9}{|l|}{ Fodder shrubs and trees } \\
\hline Fodder shrubs & 60.7 & 24.4 & 44.1 & 31.6 & 38.8 & 47.4 & 88.3 & 50.0 \\
\hline Tree Lucerne & 23.0 & 3.8 & 11.8 & 10.5 & 6.0 & 5.3 & 10.0 & 3.1 \\
\hline \multicolumn{9}{|l|}{ Conserved feeds } \\
\hline Silage making & 77.0 & 61.8 & 23.5 & 42.1 & 50.7 & 68.4 & 75.0 & 71.9 \\
\hline Conservation of crop residues & 68.9 & 52.7 & 44.1 & 21.1 & 20.9 & 42.1 & 93.3 & 50.0 \\
\hline Hay baling & 68.9 & 30.5 & 14.7 & 26.3 & 20.9 & 36.8 & 71.7 & 40.6 \\
\hline \multicolumn{9}{|l|}{ Other fodder crops } \\
\hline Sorghum & 34.4 & 13.7 & 0.0 & 15.8 & 11.9 & 10.5 & 81.7 & 9.4 \\
\hline Oats & 34.4 & 0.8 & 0.0 & 52.6 & 26.9 & 42.1 & 13.3 & 3.1 \\
\hline Edible cana & 1.6 & 0.8 & 0.0 & 5.3 & 0.0 & 5.3 & 0.0 & 9.4 \\
\hline Sweet potato vines & 62.3 & 15.3 & 11.8 & 5.3 & 4.5 & 15.8 & 76.7 & 34.4 \\
\hline Mulberry & 4.9 & 0.8 & 0.0 & 0.0 & 1.5 & 0.0 & 10.0 & 0.0 \\
\hline \multicolumn{9}{|l|}{ Other feeds } \\
\hline Feed formulation & 54.1 & 34.4 & 17.6 & 26.3 & 25.4 & $52 .^{3}$ & 58.3 & 18.8 \\
\hline Concentrates & 65.6 & 53.4 & 52.9 & 36.8 & 16.4 & 31.6 & 78.3 & 40.6 \\
\hline Mineral supplementation & 75.4 & 55.0 & 58.8 & 42.1 & 23.9 & 36.8 & 83.3 & 56.3 \\
\hline
\end{tabular}


Table 26: Percentage of farmers trained on livestock feed technologies by institution

\begin{tabular}{|c|c|c|c|c|c|c|c|c|c|c|}
\hline Feed technology & $\begin{array}{l}\text { CESPs } \\
\mathrm{N}=240\end{array}$ & $\begin{array}{l}\text { Neighbours } \\
\mathrm{N}=196\end{array}$ & $\begin{array}{l}\text { MoALFD } \\
\mathrm{N}=161\end{array}$ & $\begin{array}{l}\text { Input } \\
\text { dealers } \\
\mathrm{N}=80\end{array}$ & $\begin{array}{l}\text { Self* } \\
\mathrm{N}=72\end{array}$ & $\begin{array}{l}\text { VFT } \\
N=46\end{array}$ & $\begin{array}{l}\mathrm{NGO} \\
\mathrm{N}=43\end{array}$ & $\begin{array}{l}\text { FTC } \\
\mathrm{N}=42\end{array}$ & $\begin{array}{l}\text { KARI } \\
\mathrm{N}=27\end{array}$ & $\begin{array}{l}\text { ASK } \\
N=14\end{array}$ \\
\hline \multicolumn{11}{|l|}{ Grasses } \\
\hline Napier grass & 39.7 & 25.5 & 24.1 & 2.6 & 11.1 & 5.7 & 5.7 & 5.7 & 2.4 & 1.4 \\
\hline Rhodes & 31.2 & 17.3 & 16.8 & 3.5 & 4.5 & 4.5 & 2.1 & 4.3 & 2.1 & 0.7 \\
\hline Columbus grass & 1.7 & 0.9 & 1.2 & 0.5 & 0 & 0.2 & 0 & 0.2 & 0 & 0 \\
\hline Giant setaria & 0.9 & 0.5 & 0.7 & 0.5 & 0.2 & 0.5 & 0.7 & 0 & 0 & 0 \\
\hline \multicolumn{11}{|l|}{ Herbaceous legumes } \\
\hline Lucern & 18.4 & 4.5 & 8.5 & 1.7 & 0.7 & 0.7 & 2.6 & 1.4 & 1.2 & 0.9 \\
\hline Desmodium & 12.8 & 1.9 & 5.9 & 1.4 & 0.2 & 0.5 & 1.7 & 0.2 & 0.9 & 0 \\
\hline Purple vetch & 0.5 & 0.2 & 0.2 & 0 & 0 & 0 & 0.2 & 0.2 & 0 & 0.2 \\
\hline Lablab & 0.2 & 0.2 & 0 & 0 & 0 & 0 & 0 & 0 & 0 & 0 \\
\hline Lupine & 1.2 & 1.2 & 0 & 0.2 & 0 & 0.5 & 0.7 & 0 & 0.5 & 0.2 \\
\hline \multicolumn{11}{|l|}{ Fodder shrubs and trees } \\
\hline Fodder shrubs & 25.8 & 4.7 & 14.9 & 0 & 1.9 & 5.7 & 5.9 & 1.4 & 1.4 & 0.9 \\
\hline Tree lucern & 3.5 & 1.2 & 2.4 & 0 & 0.2 & 0.5 & 1.2 & 0 & 0.5 & 0 \\
\hline \multicolumn{11}{|l|}{ Conserved feeds } \\
\hline Silage & 30.7 & 16.3 & 17.0 & 0.7 & 1.4 & 3.1 & 5.2 & 3.5 & 1.4 & 1.9 \\
\hline Conservation of crop residues & 27.4 & 13.2 & 17.3 & 1.2 & 5.2 & 4.3 & 4.5 & 2.8 & 1.4 & 0.5 \\
\hline Hay baling & 23.2 & 6.1 & 12.3 & 0.7 & 0.7 & 4.0 & 3.3 & 1.9 & 1.4 & 0.7 \\
\hline \multicolumn{11}{|l|}{ Other fodder crops } \\
\hline Sorghum & 15.8 & 3.3 & 6.9 & 0.9 & 0.5 & 1.4 & 1.7 & 0.9 & 0.5 & 0 \\
\hline Oats & 6.9 & 2.4 & 3.8 & 0.7 & 0 & 1.9 & 0.7 & 0.5 & 1.2 & 0.5 \\
\hline Edible cana & 0.2 & 0.2 & 0.2 & 0 & 0 & 0 & 0.2 & 0.2 & 0.2 & 0 \\
\hline Sweet potato vines & 11.8 & 6.9 & 9.2 & 0.2 & 1.2 & 4.5 & 1.4 & 1.9 & 1.2 & 0.5 \\
\hline Mulberry & 0.2 & 0.7 & 0 & 0.2 & 0.2 & 0.5 & 0 & 0 & 0 & 0 \\
\hline \multicolumn{11}{|l|}{ Other feeds } \\
\hline Concentrates & 18.4 & 12.3 & 10.4 & 10.2 & 5.9 & 3.3 & 3.1 & 5.0 & 2.4 & 1.2 \\
\hline Feed formulation & 21.7 & 6.9 & 11.6 & 0.9 & 2.6 & 2.6 & 2.1 & 2.1 & 0.7 & 0 \\
\hline Mineral supplementation & 20.8 & 13.7 & 14.9 & 11.3 & 5.0 & 5.0 & 3.3 & 6.1 & 2.1 & 0.7 \\
\hline
\end{tabular}

$\mathbf{N}=$ number of farmers trained by a particular institution; *self means learning through one's own experimentation 
Table 27: Percentage of farmers reporting on frequency of training by institutions in the past six months

\begin{tabular}{|c|c|c|c|c|c|c|c|c|c|c|}
\hline $\begin{array}{l}\text { No. of times } \\
\text { trained }\end{array}$ & $\begin{array}{l}\text { CESPs } \\
\mathrm{N}=240 \\
\end{array}$ & $\begin{array}{r}\text { Neighbours } \\
\mathbf{N}=196 \\
\end{array}$ & $\begin{array}{r}\text { MoALFD } \\
\mathbf{N}=161 \\
\end{array}$ & $\begin{array}{r}\text { Input dealers } \\
\mathbf{N}=\mathbf{8 0} \\
\end{array}$ & $\begin{array}{r}\text { Self } \\
\mathrm{N}=72 \\
\end{array}$ & $\begin{array}{r}\text { VFT } \\
\mathrm{N}=46 \\
\end{array}$ & $\begin{array}{l}\text { NGO } \\
\mathrm{N}=43 \\
\end{array}$ & $\begin{array}{r}\text { FTC } \\
\mathrm{N}=42 \\
\end{array}$ & $\begin{array}{r}\text { KARI } \\
\mathbf{N}=\mathbf{2 7} \\
\end{array}$ & $\begin{array}{r}\text { ASK } \\
\mathbf{N}=13 \\
\end{array}$ \\
\hline Once & 18.3 & 19.4 & 32.3 & 11.3 & 18.1 & 17.4 & 14 & 31 & 48.1 & 46.2 \\
\hline Thrice & 8.3 & 6.1 & 0.6 & 8.8 & 1.4 & 13 & 4.7 & 11.9 & 0 & 7.7 \\
\hline Every month & 20 & 10.7 & 10.6 & 7.5 & 5.6 & 21.7 & 7.0 & 4.8 & 0 & 0 \\
\hline Every two weeks & 3.3 & 4.1 & 0.6 & 1.3 & 0 & 0 & 0 & 0 & 0 & 0 \\
\hline
\end{tabular}




\subsection{Technology sharing/multiplier effect}

From earlier discussions (Table 22) it was reported that $90 \%$ of farmers were trained. Further analysis was conducted to find out whether farmers shared information with others about the technologies they had been trained on. About $72 \%$ of the trained farmers did share information signifying the role of farmers in information dissemination. However, the proportion of male farmers $(76.8 \%)$ who shared information was significantly higher $(\mathrm{p}<0.05)$ compared to that of female farmers $(66.3 \%)$. Disaggregating by gender, $76.8 \%$ of male farmers reported that they shared information on the technologies trained whereas $66.3 \%$ of female farmers did. Both male and female farmers shared a mean of 3.5 technologies. No significant differences were detected across the two genders. Women from female-headed households (69.5\%) shared information on the new technologies with fellow farmers more than did women from male-headed households (53.8\%). The difference was marginally significant at $\mathrm{p}<0.1$. The mean number of technologies shared was not significantly different between the two categories with female-headed households sharing 3.62 technologies and women in male-headed households sharing 3.47 technologies.

Table 28 shows number of technologies on which information has been shared. About 27.9\% of farmers did not share information on livestock feed technologies with other farmers. However, $23.2 \%$ of the farmers did share information on three different livestock feed technologies. About $12.1 \%$ and $12.5 \%$ of the farmers shared two and four technologies, respectively. With regard to gender, male farmers shared information on a maximum of 10 technologies, higher than a maximum of 7 technologies shared by female farmers.

Table 28: Number of technologies shared by farmers

\begin{tabular}{lllllll}
\hline $\begin{array}{l}\text { Number of } \\
\text { technologies } \\
\text { shared }\end{array}$ & \multicolumn{2}{l}{ Male farmers } & $\mathbf{( N = 2 3 3 )}$ & \multicolumn{2}{l}{ Female farmers $(\mathbf{N}=190)$} & \multicolumn{2}{l}{ Total $(\mathbf{N}=\mathbf{4 2 3})$} \\
\hline 0 & Frequency & Percent & Frequency & Percent & Frequency & Percent \\
1 & 54 & 23.2 & 64 & 33.7 & 118 & 27.9 \\
2 & 26 & 11.2 & 8 & 4.2 & 34 & 8 \\
3 & 29 & 12.5 & 22 & 11.8 & 51 & 12.1 \\
4 & 58 & 24.9 & 40 & 21.1 & 98 & 23.2 \\
5 & 25 & 10.7 & 28 & 14.7 & 53 & 12.5 \\
6 & 17 & 7.3 & 14 & 7.4 & 31 & 7.3 \\
7 & 6 & 2.6 & 10 & 5.3 & 16 & 3.8 \\
8 & 9 & 3.9 & 4 & 2.1 & 13 & 3.1 \\
9 & 4 & 1.7 & 0 & 0 & 4 & 0.9 \\
10 & 2 & 0.9 & 0 & 0 & 2 & 0.5 \\
Total & 3 & 1.3 & 0 & 0 & 3 & 0.7 \\
\hline
\end{tabular}

There were more women from female-headed households that did not share any technology compared to those in male-headed households (Table 29). The highest number of technologies shared was three for women in both households. Only $2.6 \%$ and $2 \%$ of the female farmers from female-headed households and male-headed households shared information on 7 technologies. 
Table 29: Number of technologies shared by trained women

\begin{tabular}{lllll}
\hline $\begin{array}{l}\text { Number of } \\
\text { technologies } \\
\text { shared }\end{array}$ & $\begin{array}{l}\text { Women in female-headed } \\
\text { households } \\
\text { Frequency }\end{array}$ & $\begin{array}{l}\text { Percent } \\
\text { Pr) }\end{array}$ & \multicolumn{2}{l}{$\begin{array}{l}\text { Female in male-headed } \\
\text { households }(\mathbf{N}=\mathbf{1 5 1})\end{array}$} \\
\hline 0 & 18 & 46.2 & 46 & Prequency \\
1 & 2 & 5.1 & 6 & 30.5 \\
2 & 3 & 7.7 & 19 & 4 \\
3 & 6 & 15.4 & 34 & 12.6 \\
4 & 4 & 10.3 & 24 & 22.5 \\
5 & 3 & 7.7 & 11 & 15.9 \\
6 & 2 & 5.1 & 8 & 7.3 \\
7 & 1 & 2.6 & 3 & 5.3 \\
Total & $\mathbf{3 9}$ & $\mathbf{1 0 0}$ & $\mathbf{1 5 1}$ & $\mathbf{1 0 0}$ \\
\hline
\end{tabular}

There was considerable variation among sites in the proportion of farmers sharing information with other farmers. Nearly all (98\%) farmers in Sot shared information (Table 30 ). More than $80 \%$ did so in Cherang'ani and Kieni. Information sharing was low among farmers in Olkalou and Taragoon, which could be pegged perhaps to their big farm size, sparse population and long distance between farmers' households.

Table 30: Percentage of farmers sharing information by site

\begin{tabular}{lll}
\hline Site & $\mathbf{N}$ & \% farmers \\
\hline Sot & 56 & 98.3 \\
Cherang'ani & 85 & 91.8 \\
Kieni & 27 & 87.5 \\
Kapcheno & 10 & 79.4 \\
Taragoon & 27 & 68.4 \\
Tanykina & 13 & 64.9 \\
Metkei & 59 & 52.6 \\
Olkalou & 28 & 40.3 \\
\hline
\end{tabular}

\subsubsection{Types of feed technologies shared by gender}

As can be seen in Table 31, the top three shared technologies were Napier grass $(75.4 \%)$, conservation of crop residues (46.9\%) and mineral supplementation $(39.3 \%)$. There were few differences between genders. A greater percentage of female farmers shared information on Napier grass and mineral supplementation than male farmers who disseminated information on Lucerne more than women did.

The least shared technologies were edible cana and lupine. This could be because farmers did not have adequate understanding of these feeds. In fact, the previous findings showed that less than $5 \%$ of farmers interviewed across sites had accessed information on these feeds and less than $5 \%$ of farmers were trained on them. Similar results were reported by Kiptot and Franzel (2012). 
Table 31: Types of feed technologies shared by farmers

\begin{tabular}{|c|c|c|c|c|}
\hline Feed technology & $\mathbf{N}$ & $\begin{array}{l}\text { \% male } \\
(\mathrm{N}=179)\end{array}$ & $\begin{array}{l}\text { \% female } \\
(\mathrm{N}=126)\end{array}$ & $\begin{array}{l}\text { \% total } \\
(\mathrm{N}=305)\end{array}$ \\
\hline \multicolumn{5}{|l|}{ Grasses } \\
\hline Napier grass & 230 & 71.5 & $81.0^{*}$ & 75.4 \\
\hline Rhodes grass & 113 & 37.4 & 36.5 & 37.0 \\
\hline Columbus grass & 4 & 0 & $3.2 * *$ & 1.3 \\
\hline Giant setaria & 0 & 0 & 0 & 0 \\
\hline \multicolumn{5}{|l|}{ Herbaceous legumes } \\
\hline Lucerne & 33 & 14.5 & $5.6^{* *}$ & 10.8 \\
\hline Desmodium & 20 & 7.8 & 4.8 & 6.6 \\
\hline Purple vetch & 2 & 1.1 & 0.0 & 0.7 \\
\hline Lablab & 2 & 1.1 & 0.0 & 0.7 \\
\hline Lupine & 1 & 0.6 & 0.0 & 0.3 \\
\hline \multicolumn{5}{|l|}{ Fodder shrubs and trees } \\
\hline Fodder shrubs & 50 & 16.8 & 15.9 & 16.4 \\
\hline Tree Lucerne & 3 & 1.7 & 0.0 & 1.0 \\
\hline \multicolumn{5}{|l|}{ Conserved feeds } \\
\hline $\begin{array}{l}\text { Conservation of crop } \\
\text { residues }\end{array}$ & 143 & 45.3 & 49.2 & 46.9 \\
\hline Silage making & 57 & 20.7 & 15.9 & 18.7 \\
\hline Hay baling & 34 & 12.3 & 9.5 & 11.1 \\
\hline \multicolumn{5}{|l|}{ Other fodder crops } \\
\hline Sweet potato & 68 & 20.7 & 24.6 & 22.3 \\
\hline Oats & 23 & 8.4 & 6.3 & 7.5 \\
\hline Sorghum & 17 & 5.6 & 5.6 & 5.6 \\
\hline Edible cana & 1 & 0.6 & 0.0 & 0.3 \\
\hline \multicolumn{5}{|l|}{ Other feeds } \\
\hline Mineral supplementation & 120 & 34.1 & $46.8^{* *}$ & 39.3 \\
\hline Concentrates & 83 & 27.9 & 26.2 & 27.2 \\
\hline Feed formulation & 49 & 16.2 & 15.9 & 16.1 \\
\hline
\end{tabular}

$* * * p<0.01, * * p<0.05, * p<0.1$

Results in Table 32 show a mixed pattern on information sharing between women in male and female-headed households with the latter leading in nine technologies and the former in six. Significant differences were recorded on only two technologies: sorghum and conservation of crop residues. 
Table 32: Types of feed technologies shared by women farmers

\begin{tabular}{|c|c|c|c|c|}
\hline Feed technology & \multirow{2}{*}{\multicolumn{2}{|c|}{$\begin{array}{r}\% \text { women in } \\
\text { female-headed } \\
\text { households }(\mathrm{N}=21)\end{array}$}} & \multicolumn{2}{|c|}{$\begin{array}{l}\text { \% female in male- } \\
\text { headed households }\end{array}$} \\
\hline \multirow{2}{*}{\multicolumn{5}{|c|}{ Grasses }} \\
\hline & & & & \\
\hline Napier grass & 18 & 85.7 & 84 & 80 \\
\hline Rhodes grass & 8 & 38.1 & 38 & 36.2 \\
\hline Columbus grass & 0 & 0 & 4 & 3.8 \\
\hline Giant setaria & 0 & 0 & 0 & 0 \\
\hline \multicolumn{5}{|l|}{ Herbaceous legumes } \\
\hline Lucerne & 2 & 9.5 & 5 & 4.8 \\
\hline Desmodium & 0 & 0 & 6 & 5.7 \\
\hline Purple vetch & 0 & 0 & 0 & 0 \\
\hline Lablab & 0 & 0 & 0 & 0 \\
\hline Lupine & 0 & 0 & 0 & 0 \\
\hline \multicolumn{5}{|l|}{ Fodder trees and shrubs } \\
\hline Fodder shrubs & 3 & 17.6 & 13 & 13.9 \\
\hline Tree lucern & 0 & 0 & 0 & 0 \\
\hline \multicolumn{5}{|l|}{ Conserved feeds } \\
\hline Conservation of crop residues & 6 & 28.6 & 56 & $53.3 * *$ \\
\hline Silage making & 2 & 9.5 & 18 & 17.1 \\
\hline Hay baling & 3 & 14.3 & 9 & 8.6 \\
\hline \multicolumn{5}{|l|}{ Other fodder crops } \\
\hline Sweet potato vines & 4 & 19.0 & 27 & 25.7 \\
\hline Oats & 2 & 9.5 & 6 & 5.7 \\
\hline Sorghum & 4 & 19.0 & 3 & $2.9 * * *$ \\
\hline Edible cana & 0 & 0 & 0 & 0 \\
\hline \multicolumn{5}{|l|}{ Other feeds } \\
\hline Mineral supplementation & 7 & 33.3 & 52 & 49.5 \\
\hline Concentrates & 8 & 38.1 & 25 & 23.8 \\
\hline Feed formulation & 5 & 23.8 & 15 & 14.3 \\
\hline
\end{tabular}

\subsection{Livestock feed technologies practised}

Presented in Table 33 are the results of livestock feed technologies that farmers have tried to practise in their lifetime. The study assumed that feed technologies practised depend on the individuals as opposed to household heads. In general, the three most frequently practised technologies were mineral supplementation, Napier grass and concentrates. This was similar for both male and female farmers. As a matter of fact, the proportions using the top 10 technologies did not vary much except that there were significantly more men practising Rhodes grass and desmodium feed technologies than women. 
Table 33: Technologies practised by gender

\begin{tabular}{|c|c|c|c|}
\hline Feed technology type & $\%$ male $(\mathrm{N}=233)$ & $\%$ female $(\mathrm{N}=190)$ & $\%$ total $(\mathrm{N}=423)$ \\
\hline \multicolumn{4}{|l|}{ Grasses } \\
\hline Napier grass & 82.0 & 81.6 & 81.3 \\
\hline kikuyu grass & 47.6 & 47.4 & 47.5 \\
\hline Rhodes grass & 43.3 & $30.0 * * *$ & 37.4 \\
\hline Rye grass & 3.4 & 5.8 & 4.5 \\
\hline Giant setaria & 0.9 & 2.6 & 1.4 \\
\hline Columbus grass & 0.9 & 1.6 & 1.2 \\
\hline \multicolumn{4}{|l|}{ Herbaceous legumes } \\
\hline Lucerne & 10.3 & $5.3 *$ & 8.0 \\
\hline Desmodium & 8.6 & $1.3 * * *$ & 5.2 \\
\hline Purple vetch & 3.0 & 1.6 & 2.4 \\
\hline Lupine & 1.7 & 0.7 & 1.2 \\
\hline Lablab & 1.3 & 1.3 & 1.2 \\
\hline \multicolumn{4}{|l|}{ Fodder shrubs and trees } \\
\hline Fodder shrubs & 16.3 & 13.7 & 14.7 \\
\hline Tree Lucerne & 3.4 & 2.6 & 2.8 \\
\hline \multicolumn{4}{|l|}{ Conserved feeds } \\
\hline Conservation of crop residues & 52.4 & 56.8 & 54.4 \\
\hline Silage making & 15.5 & 13.7 & 14.7 \\
\hline Hay baling & 13.3 & 14.2 & 13.7 \\
\hline \multicolumn{4}{|l|}{ Other fodder crops } \\
\hline Sweet potato vines & 20.6 & 17.4 & 19.1 \\
\hline Oats & 18.0 & 12.6 & 15.6 \\
\hline Sorghum & 9.4 & 10.0 & 9.7 \\
\hline Edible cana & 2.1 & $0.0 *$ & 1.2 \\
\hline \multicolumn{4}{|l|}{ Other feeds } \\
\hline Mineral supplementation & 100 & 100 & 100 \\
\hline Concentrates & 52.8 & 58.4 & 55.3 \\
\hline Feed formulation & 13.7 & 17.9 & 15.6 \\
\hline
\end{tabular}

$* * * \mathrm{p}<0.01,{ }^{* *} \mathrm{p}<0.05, * \mathrm{p}<0.1$

There were few differences between female farmers in male-headed and female-headed households. Conservation of crop residues was practised more by female farmers in maleheaded households than single women. However, single women surpassed women in maleheaded households in using sorghum and rye grass (Table 34 ). 
Table 34: Technologies practised by female heads and women in male-headed households

\begin{tabular}{lll}
\hline Technology practised & $\begin{array}{l}\text { \% female-headed } \\
\text { households }(\mathbf{N}=\mathbf{3 9})\end{array}$ & $\begin{array}{l}\text { \% female in male-headed } \\
\text { households } \mathbf{( N = 1 5 1 )}\end{array}$ \\
\hline Grasses & & \\
Napier grass & 74.4 & 82.8 \\
Kikuyu grass & 35.9 & 50.3 \\
Rhodes grass & 23.1 & 31.8 \\
Rye grass & 12.8 & $4.0^{* *}$ \\
Giant setaria & 0 & 2.6 \\
Columbus grass & 2.6 & 1.3 \\
Herbaceous legumes & & \\
Lucerne & 7.7 & 4.6 \\
Desmodium & 0 & 1.3 \\
Purple vetch & 2.6 & 1.3 \\
Lablab & 0 & 1.3 \\
Lupine & 0 & 0.7 \\
Fodder shrubs and trees & & \\
Fodder shrubs & 10.3 & 13.9 \\
Tree Lucerne & 0 & 2.6 \\
Other fodder crops & & \\
Sweet potato vines & 10.3 & 19.2 \\
Oats & 17.9 & 11.3 \\
Sorghum & 20.5 & $7.3 * *$ \\
Conserved feeds & & \\
Conservation of crop & & $62.3 * * *$ \\
residues & 35.9 & 15.2 \\
Silage making & 7.7 & 13.2 \\
Hay baling & 17.9 & 100 \\
Other feeds & & 58.3 \\
Mineral supplementation & 100 & \\
Concentrates & 59.0 & \\
Feed formulation & 15.4 & \\
\hline$* 0.5$ \\
\hline
\end{tabular}

$* * * \mathrm{p}<0.01, * * \mathrm{p}<0.05, * \mathrm{p}<0.1$ 
Analysis of livestock feed technologies practised by site shows considerable variation across regions (Table 35). Majority of the farmers (>85\%) in the UM areas of Rift Valley, mainly Tanykina and Kapcheno sites in Nandi county, used kikuyu grass, which is natural and common in the area. Similar findings were reported in Olkalou and Metkei sites in UH areas of Rift valley. In addition to that, farmers in Olkalou and Metkei also used oats for feeding their livestock. It can be said that farmers use feeds that are available locally. Furthermore, most of the farmers in these sites had relatively large farm sizes that could have slowed down the adoption of intensive technologies in favour of the free grazing system characterized by use of natural grass. This is why, contrary to these indications, farmers in Cherang'ani, an UM area and those from Kieni, a LM area, used Napier grass more than kikuyu grass.

Cherang'ani and Kieni farmers own relatively small land sizes and are therefore likely to adopt intensive livestock feeding technologies such as silage and hay that are suitable for the confined grazing system. In LH areas, particularly Sot and Taragoon, the commonly used livestock feed technologies were conservation of crop residues and Napier grass. This was so perhaps because the region receives slightly less rain and therefore farmers tend to use feeds with long storage life span. The use of herbaceous legumes was relatively low in all sites. Fodder shrubs were common in Kapcheno, Sot and Kieni areas, but were not used in Metkei. 
Table 35: Technologies practised by farmers by site

\begin{tabular}{|c|c|c|c|c|c|c|c|c|c|}
\hline Feed technology & $\begin{array}{l}\text { Total } \\
(\mathrm{N}=423)\end{array}$ & $\begin{array}{l}\text { Cherang'ani } \\
(\mathrm{N}=56)\end{array}$ & $\begin{array}{l}\text { Tanykina } \\
(\mathrm{N}=85)\end{array}$ & $\begin{array}{l}\text { Kapcheno } \\
(\mathbf{N}=27)\end{array}$ & $\begin{array}{l}\text { Metkei } \\
(\mathrm{N}=\mathbf{1 0})\end{array}$ & $\begin{array}{l}\text { Olkalou } \\
(\mathrm{N}=27)\end{array}$ & $\begin{array}{l}\text { Taragoon } \\
(\mathrm{N}=13)\end{array}$ & $\begin{array}{l}\text { Sot } \\
(N=59)\end{array}$ & $\begin{array}{l}\text { Kieni } \\
(\mathrm{N}=\mathbf{2 8})\end{array}$ \\
\hline \multicolumn{10}{|l|}{ Grasses } \\
\hline Napier grass & 81.6 & 95.1 & 70.2 & 88.2 & 78.9 & 76.1 & 47.3 & 96.7 & 100 \\
\hline kikuyu grass & 81.1 & 73.8 & 95.4 & 88.2 & 89.5 & 59.7 & 78.9 & 85 & 0 \\
\hline Rhodes grass & 36.2 & 50.9 & 48.1 & 14.7 & 10.5 & 11.9 & 5.3 & 58.3 & 25 \\
\hline Rye grass & 4.5 & 0 & 0 & 0 & 0 & 28.4 & 0 & 0 & 0 \\
\hline Giant setaria & 1.4 & 1.6 & 0.8 & 0 & 0 & 5.9 & 0 & 0 & 0 \\
\hline Columbus grass & 1.2 & 1.6 & 0 & 0 & 0 & 5.9 & 0 & 0 & 0 \\
\hline \multicolumn{10}{|l|}{ Herbaceous legumes } \\
\hline Lucerne & 8.3 & 13.1 & 3.1 & 0 & 0 & 11.9 & 0 & 8.3 & 31.3 \\
\hline Purple vetch & 2.4 & 0 & 0 & 0 & 5.3 & 11.9 & 0 & 1.7 & 0 \\
\hline Lablab & 1.2 & 0 & 0 & 0 & 0 & 2.9 & 5.3 & 3.3 & 0 \\
\hline Desmodium & 5.2 & 6.6 & 0.8 & 0 & 0 & 1.5 & 0 & 16.7 & 18.8 \\
\hline Lupine & 1.2 & 0 & 0 & 0 & 5.3 & 5.9 & 0 & 0 & 0 \\
\hline \multicolumn{10}{|l|}{ Fodder shrubs and trees } \\
\hline Fodder shrubs & 14.7 & 11.5 & 10.7 & 26.5 & 0 & 8.9 & 10.5 & 28.3 & 21.9 \\
\hline Tree Lucerne & 2.8 & 1.6 & 3.1 & 0 & 5.3 & 2.9 & 0 & 3.3 & 6.3 \\
\hline \multicolumn{10}{|l|}{ Other fodder crops } \\
\hline Sweet potato vines & 19.2 & 24.6 & 11.5 & 2.9 & 0 & 2.9 & 10.5 & 55 & 40.6 \\
\hline Oats & 15.6 & 1.6 & 0 & 0 & 84.2 & 68.7 & 5.3 & 3.3 & 0 \\
\hline Sorghum & 9.7 & 1.6 & 4.6 & 0 & 5.3 & 14.9 & 5.3 & 31.7 & 9.4 \\
\hline Edible cana & 1.2 & 1.6 & 0.8 & 0 & 0 & 1.5 & 0 & 0 & 6.3 \\
\hline \multicolumn{10}{|l|}{ Conserved feeds } \\
\hline Conservation of crop residues & 56.0 & 49.2 & 70.2 & 41.2 & 26.3 & 41.8 & 84.2 & 46.7 & 75 \\
\hline Silage & 14.7 & 21.3 & 19.1 & 5.9 & 5.3 & 17.9 & 26.3 & 3.3 & 6.3 \\
\hline Hay baling & 13.5 & 22.9 & 6.1 & 0 & 5.3 & 17.9 & 21.1 & 15 & 28.1 \\
\hline \multicolumn{10}{|l|}{ Other feeds } \\
\hline Mineral supplementation & 100 & 100 & 100 & 100 & 100 & 100 & 100 & 100 & 100 \\
\hline Concentrates & 55.6 & 40.9 & 67.2 & 55.9 & 52.6 & 41.8 & 63.2 & 60 & 53.1 \\
\hline Feed formulation & 15.8 & 22.9 & 20.6 & 2.9 & 21.1 & 13.4 & 15.8 & 6.7 & 15.6 \\
\hline
\end{tabular}




\subsection{Preference for livestock feed technologies practised}

Ranking of preferred livestock feed technologies was done using the method explained in section 2. Out of all the feed technologies practised by farmers, Napier grass, kikuyu grass and conservation of crop residues were the three most preferred feed technologies in that order (Table 36). This was true for both male and female farmers.

Feed technology preference differed across sites with farmers in Cherang'ani, Kapcheno, Metkei, Olkalou and Kieni preferring Napier grass to other feed technologies while those in Tanykina and Sot preferred kikuyu grass (Table 37). Taragoon farmers preferred conservation of crop residues. 
Table 36: Ranking of farmers' preference for livestock feed technologies practised by gender

\begin{tabular}{|c|c|c|c|c|c|c|c|c|c|}
\hline Feed technology & $\begin{array}{l}\text { Male }(\mathbf{N}=233) \\
\text { Total frequency } \\
\text { (Total score) }\end{array}$ & $\begin{array}{l}\text { Average } \\
\text { score }\end{array}$ & Rank & $\begin{array}{l}\text { Female }(\mathrm{N}=190) \\
\text { Total frequency } \\
\text { (Total score) }\end{array}$ & $\begin{array}{l}\text { Average } \\
\text { score }\end{array}$ & Rank & $\begin{array}{l}\text { Total }(\mathrm{N}=423) \\
\text { Total frequency } \\
\text { (Total score) }\end{array}$ & $\begin{array}{l}\text { Average } \\
\text { score }\end{array}$ & Rank \\
\hline \multicolumn{10}{|l|}{ Grasses } \\
\hline Napier grass & $(156) 382$ & 2.45 & 1 & $(135) 325$ & 2.41 & 1 & $(291) 707$ & 2.43 & 1 \\
\hline kikuyu grass & $(95) 221$ & 2.34 & 2 & $(80) 191$ & 2.39 & 2 & $(175) 412$ & 2.35 & 2 \\
\hline Rhodes grass & $(58) 110$ & 1.90 & 5 & $(36) 63$ & 1.75 & 6 & $(94) 173$ & 1.84 & 6 \\
\hline Rye grass & $(6) 15$ & 2.5 & 12 & $(9) 17$ & 1.89 & 11 & $(15) 32$ & 2.13 & 12 \\
\hline Giant setaria & (1)3 & 3 & 18 & (1)3 & 3 & 14 & (2) 6 & 3 & 17 \\
\hline Columbus grass & (2)3 & 1.5 & 18 & (2) 2 & 1 & 17 & (4) 5 & 1.25 & 18 \\
\hline \multicolumn{10}{|l|}{ Herbaceous legumes } \\
\hline Lucerne & (10)14 & 1.4 & 13 & (1)3 & 3 & 14 & (11)17 & 1.55 & 14 \\
\hline Desmodium & (7) 9 & 1.29 & 15 & $(0) 0$ & 0 & 19 & (7) 9 & 1.28 & 15 \\
\hline Purple vetch & (3) 5 & 1.67 & 16 & $(0) 0$ & 0 & 19 & (3) 5 & 1.67 & 18 \\
\hline Lablab & (2) 3 & 1.5 & 18 & (1) 1 & 1 & 18 & (3) 4 & 1.33 & 20 \\
\hline Lupine & (1) 1 & 1 & 21 & $(0) 0$ & 0 & 19 & (1) 1 & 1 & 21 \\
\hline \multicolumn{10}{|l|}{ Fodder shrubs and trees } \\
\hline Fodder shrubs & (14) 27 & 1.93 & 10 & (11)21 & 1.91 & 10 & $(25) 48$ & 1.92 & 10 \\
\hline Tree Lucerne & (1) 1 & 1 & 21 & $(0) 0$ & 0 & 19 & (1) 1 & 1 & 21 \\
\hline \multicolumn{10}{|l|}{ Other fodder crops } \\
\hline Oats & $(36) 79$ & 2.19 & 7 & $(20) 40$ & 2 & 7 & (56)119 & 2.13 & 7 \\
\hline Sweet potato vines & (8) 13 & 1.63 & 14 & (8) 11 & 1.38 & 13 & (16)24 & 1.5 & 13 \\
\hline Sorghum & (3) 4 & 1.33 & 17 & $(2) 3$ & 1.5 & 14 & $(5) 7$ & 1.4 & 16 \\
\hline Edible cana & (1) 1 & 1 & 21 & $(0) 0$ & 0 & 19 & (1) 1 & 1 & 21 \\
\hline \multicolumn{10}{|l|}{ Conserved feeds } \\
\hline Conservation of crop residues & (84) 174 & 2.07 & 3 & (69)146 & 2.12 & 3 & $(153) 320$ & 2.09 & 3 \\
\hline Silage making & (27)36 & 1.33 & 8 & $(10) 22$ & 2.2 & 9 & $(37) 58$ & 1.57 & 9 \\
\hline Hay baling & (18)21 & 1.17 & 11 & (8) 16 & 2 & 12 & $(26) 37$ & 1.42 & 11 \\
\hline \multicolumn{10}{|l|}{ Other feeds } \\
\hline Concentrates & (74) 117 & 1.58 & 4 & (64)109 & 1.7 & 4 & (138)226 & 1.64 & 4 \\
\hline Mineral supplementation & $(75) 99$ & 1.32 & 6 & (78)109 & 1.4 & 4 & (153)208 & 1.36 & 5 \\
\hline Feed formulation & (14)30 & 2.14 & 9 & (18)36 & 2 & 8 & (32) 66 & 2.06 & 8 \\
\hline
\end{tabular}

Total score is the sum of scores for each preference. Scores were got by multiplying frequencies on each preference level by scores assigned where low preference was given a score of

1 , medium a score of 2 and high a score of 3 
Table 37: Ranking of farmers' preferred livestock feed technologies practised by site

\begin{tabular}{|c|c|c|c|c|c|c|c|c|}
\hline Feed technology & $\begin{array}{l}\text { Cherang'ani } \\
(\mathrm{N}=61)\end{array}$ & $\begin{array}{l}\text { Tanykina } \\
(\mathrm{N}=131)\end{array}$ & $\begin{array}{l}\text { Kapcheno } \\
(\mathrm{N}=34)\end{array}$ & $\begin{array}{l}\text { Metkei } \\
(\mathrm{N}=19)\end{array}$ & $\begin{array}{l}\text { Olkalou } \\
(\mathrm{N}=67)\end{array}$ & $\begin{array}{l}\text { Taragoon } \\
(\mathrm{N}=19)\end{array}$ & $\begin{array}{l}\text { Sot } \\
(\mathrm{N}=60)\end{array}$ & $\begin{array}{l}\text { Kieni } \\
(\mathrm{N}=32)\end{array}$ \\
\hline Grasses & \multicolumn{8}{|c|}{ (Farmers' total scores) } \\
\hline Napier grass & $142^{1}$ & $140^{2}$ & $84^{1}$ & $33^{1}$ & $98^{1}$ & $17^{3}$ & $117^{2}$ & $76^{1}$ \\
\hline Rhodes grass & 26 & 65 & 8 & 2 & 13 & 0 & 32 & $27^{3}$ \\
\hline Columbus grass & 1 & 0 & 0 & 0 & 4 & 0 & 0 & 0 \\
\hline Rye grass & 1 & 0 & 0 & 0 & 31 & 0 & 0 & 0 \\
\hline kikuyu grass & $57^{2}$ & $207^{1}$ & 1 & $14^{3}$ & 0 & 8 & $125^{1}$ & 0 \\
\hline \multicolumn{9}{|l|}{ Herbaceous legumes } \\
\hline Lucerne & 3 & 5 & 0 & 0 & 2 & 0 & 0 & 7 \\
\hline Desmodium & 3 & 0 & 0 & 0 & 0 & 0 & 2 & 4 \\
\hline Lablab & 0 & 0 & 0 & 0 & 8 & 2 & 0 & 0 \\
\hline Lupine & 0 & 0 & 0 & 1 & 0 & 0 & 0 & 0 \\
\hline Purple vetch & 0 & 0 & 0 & 1 & 4 & 0 & 0 & 0 \\
\hline \multicolumn{9}{|l|}{ Fodder shrubs and trees } \\
\hline Fodder shrubs & 1 & 9 & 20 & 0 & 5 & 3 & 8 & 2 \\
\hline Tree Lucerne & 0 & 0 & 0 & 0 & 1 & 0 & 0 & 0 \\
\hline Sorghum & 0 & 0 & 0 & 4 & 5 & 0 & 2 & 0 \\
\hline Oats & 0 & 0 & 0 & $30^{2}$ & $89^{2}$ & 0 & 0 & 0 \\
\hline Edible cana & 0 & 0 & 0 & 0 & 1 & 0 & 0 & 0 \\
\hline Sweet potato vines & 4 & 4 & 3 & 0 & 0 & 0 & 10 & 3 \\
\hline \multicolumn{9}{|l|}{ Conserved feeds } \\
\hline Silage making & 2 & 23 & 2 & 2 & 17 & 10 & 0 & 2 \\
\hline Hay baling & 3 & 10 & 0 & 2 & 15 & 2 & 0 & 5 \\
\hline Conservation of crop residues & $52^{3}$ & $132^{3}$ & 21 & 5 & $33^{3}$ & $27^{1}$ & 14 & $36^{2}$ \\
\hline \multicolumn{9}{|l|}{ Other feeds } \\
\hline Feed formulation & 11 & 19 & 3 & 10 & 13 & 3 & 0 & 7 \\
\hline Concentrates & 25 & 96 & $35^{2}$ & 10 & 22 & $23^{2}$ & 8 & 7 \\
\hline Mineral supplementation & 34 & 67 & $23^{3}$ & 1 & 16 & 10 & $42^{3}$ & 15 \\
\hline
\end{tabular}

Numerical superscripts represent the rankings 
After training, it is expected that farmers will practise and/or disseminate information on the trained technologies. Results in Table 38 compare the percentages of farmers trained versus those practising technologies on farm and sharing information with fellow farmers. Of course, it is possible that farmers practising a technology or sharing it were never trained in it but nevertheless, examining the proportions in each category shows important trends. Indeed Napier grass was the only technology on which over $75 \%$ of farmers had been trained, and over $75 \%$ were practising and sharing it with others. Over $40 \%$ of farmers have been trained in six other practices, but proportions of farmers practising and sharing information about these varies. Two long-practised technologies, mineral supplementation and conservation of crop residues, had practice rates higher than training rates. One practice, Rhodes grass, had two-thirds of training rates, indicating some constraints to adoption and three had practice rates of $24-34 \%$ of training rates, indicating important constraints to adoption. These three practices were hay baling, fodder shrubs, and silage making, each of which is knowledge intensive, requiring the learning of new skills and purchase of materials. Farmers implementing practices tended to share information about them with others. Of the eight practices used by over $15 \%$ of farmers, six were shared by over $80 \%$ of those practising. The other two, mineral supplementation and concentrates, were shared by $39 \%$ and $49 \%$ of farmers, respectively.

Table 38: Percentage of farmers trained, practising and sharing information on selected feed technologies

\begin{tabular}{lrrr}
\hline Feed technology & $\begin{array}{r}\text { \% trained } \\
(\mathbf{N = 3 7 6 )}\end{array}$ & $\begin{array}{r}\text { \% practising } \\
(\mathbf{N = 4 2 3 )}\end{array}$ & $\begin{array}{r}\text { \% sharing } \\
(\mathbf{N}=\mathbf{3 0 5})\end{array}$ \\
\hline Grasses & 77.1 & 81.3 & 75.4 \\
Napier grass & 57.9 & 37.4 & 37 \\
Rhodes grass & & & \\
Herbaceous legumes & 32.2 & 8 & 10.8 \\
Lucerne & 20.6 & 5.2 & 6.6 \\
Desmodium & & & \\
Conserved feeds & 61.2 & 14.7 & 18.7 \\
Silage making & 53 & 54.4 & 46.9 \\
Conservation of crop & 40 & 13.7 & 11.1 \\
residues & 45.9 & 14.7 & 16.4 \\
Hay baling & & & \\
Fodder shrubs & 29.8 & 19.1 & 22.3 \\
Other fodder crops & 24.6 & 9.7 & 5.6 \\
Sweet potato vines & 15.8 & 15.6 & 7.5 \\
Sorghum & & & \\
Oats & 56 & 100 & 39.3 \\
Other feeds & 50.1 & 55.3 & 27.2 \\
Mineral supplementation & 37.1 & 15.6 & 16.1 \\
Concentrates & & & \\
Feed formulation & & & \\
\hline
\end{tabular}




\subsection{Test on level of understanding of livestock feed technologies}

Farmers were asked questions to gauge their understanding on certain livestock feed technologies that they have been trained on. A correct score for each test was awarded 2 points, 1 for half correct and 0 for incorrect. The overall mean score of level of understanding on livestock feed technologies was 1.54 (Table 39). Both men and women had equal understanding of the technology with a mean score of about 1.5 . Over $80 \%$ of farmers got responded to the questions on Napier grass correctly. They earned high scores in the three questions which included aspects on Napier grass establishment (1.86), planting of Napier canes (1.86) and planting of Napier root splits (1.78). Thus, Napier grass was the most understood livestock feed technology by farmers. Farmers also scored highly $(>1.7)$ on questions related to sowing Rhodes grass, types of silage and use of maize as fodder. More than $75 \%$ of farmers scored correctly on questions targeting the mentioned technologies. Questions with the lowest scores included those on fodder shrubs, particularly the number of calliandra trees required per cow per year and the number of fodder trees required to be left for seed production $(0.96)$ where only about $30 \%$ of the farmers managed to get a correct answer on each aspect.

Table 39: Farmers' mean score on understanding of livestock feed technologies

\begin{tabular}{|c|c|c|c|c|c|}
\hline Test question & $\mathbf{N}$ & $\begin{array}{l}\text { Mean } \\
\text { score }\end{array}$ & $\begin{array}{l}\text { \% Not } \\
\text { correct }\end{array}$ & $\begin{array}{l}\text { \% Partially } \\
\text { correct }\end{array}$ & $\begin{array}{l}\text { \% } \\
\text { Correc } \\
\text { t }\end{array}$ \\
\hline Napier grass establishment & $\begin{array}{l}35 \\
5 \\
34\end{array}$ & $1.86(0.38)$ & 1.1 & 11.8 & 87 \\
\hline Planting of Napier canes & $\begin{array}{l}6 \\
33\end{array}$ & $1.86(0.37)$ & 0.9 & 11.9 & 87.3 \\
\hline Planting of Napier root splits & $\begin{array}{l}7 \\
17\end{array}$ & $1.78(0.58)$ & 3.3 & 15.1 & 81.6 \\
\hline Best time to sow Rhodes grass & $\begin{array}{l}2 \\
23\end{array}$ & $1.76(0.47)$ & 1.7 & 20.7 & 77.9 \\
\hline Types of silage & $\begin{array}{l}7 \\
20\end{array}$ & $1.75(0.46)$ & 1.3 & 22.8 & 76 \\
\hline Best time for harvesting maize fodder for silage & $\begin{array}{l}7 \\
22\end{array}$ & $1.74(0.49)$ & 2.4 & 21.3 & 76.3 \\
\hline Material is needed for making tube silage & $\begin{array}{l}9 \\
18\end{array}$ & $1.69(0.55)$ & 4.4 & 22.7 & 72.9 \\
\hline Knowledge on any shrub used for fodder & $\begin{array}{l}7 \\
31\end{array}$ & $1.67(0.59)$ & 6.5 & 19.9 & 73.7 \\
\hline Best stage to cut Napier for silage & $\begin{array}{l}2 \\
15\end{array}$ & $1.59(0.63)$ & 7.4 & 26.6 & 66 \\
\hline Which is the best stage to cut Rhodes grass for making hay & 4 & $1.58(0.62)$ & 7.1 & 27.9 & 64.9 \\
\hline Is Nandi setaria an annual or perennial grass & $\begin{array}{l}41 \\
12\end{array}$ & $1.49(0.68)$ & 9.8 & 31.7 & 58.5 \\
\hline Suitable niches for growing shrubs & 4 & $1.41(0.75)$ & 16.1 & 26.6 & 57.3 \\
\hline Best season for sowing Rhodes grass & $\begin{array}{l}98 \\
10\end{array}$ & $1.33(0.74)$ & 16.3 & 34.7 & 49 \\
\hline Pretreatment of Calliandra seeds & 7 & $1.30(0.82)$ & 22.4 & 25.2 & 52.3 \\
\hline Growing mulberry with other food crops & $\begin{array}{l}34 \\
10\end{array}$ & $1.24(0.70)$ & 17.6 & 41.1 & 41.1 \\
\hline Recommended spacing for Calliandra & 2 & $1.14(0.83)$ & 28.4 & 29.4 & 42.2 \\
\hline Required number of Calliandra trees per cow per year & $\begin{array}{l}50 \\
10\end{array}$ & $0.96(0.83)$ & 36 & 32 & 32 \\
\hline $\begin{array}{l}\text { Required number of fodder trees for seed production } \\
\text { Number of } 70 \mathrm{~kg} \text { freshly cut Rhodes grass needed per cow per } \\
\text { day }\end{array}$ & 82 & $\begin{array}{l}0.96(0.80) \\
0.9(0.76)\end{array}$ & $\begin{array}{l}33.3 \\
34.2\end{array}$ & $\begin{array}{l}37.3 \\
41.4\end{array}$ & 29.4 \\
\hline Overall & & $1.54(0.3)$ & & & \\
\hline
\end{tabular}

Figures in parenthesis are standard deviations 


\subsection{DISCUSSION}

The study found that radio was the most accessed source of information on livestock feed technologies by the sampled farmers. Indeed, literature has it that a good proportion of Kenyan households have access to radios (Mzungu, 2013). The authors noted that 9 out of every 10 adults listen to radio on a weekly basis. In some of the discussions with the farmers it was reported that local radio stations such as Inooro FM, Chamgei FM and Kass FM air agricultural programmes in the local language thus making them a favorite learning media for rural farmers. Similar to these findings, Oladeji et al. (2011) noted that radio was a major source of information for farmers in Nigeria. In contrast, Boateng et al. (2014) indicated low use of radio in Ghana with farmers citing that the information passed through radio was too general and therefore not useful to their specific conditions.

The CESPs and neighbours were the second and third most accessed sources of information. The two sources were found ideal probably because of their proximity to farmers. Farmers prefer learning from their neighbours where they can copy successful technologies. Additionally, neighbours have a good understanding of the locals and are therefore better positioned to address farmers' specific needs. With regard to gender, a comparatively higher percentage of male farmers had access to a number of information sources. Examples include radio, field days, agricultural shows, skilled farmers, written materials, demonstrations, newspapers, breeders' shows, mobile phones and posters. Clearly, male farmers have more access to both electronic and interpersonal sources of information than their female counterparts. This can be explained by the fact that male farmers are more literate and therefore are more informed on available information sources. In addition, since they have fewer commitments at home than do women, they can access information sources away from the farm more readily than the women.

Relative to other sources, the VFTs were ranked $6^{\text {th }}$ overall and were accessed by $26.7 \%$ of farmers. Given that only about one-fifth of the DMGs had volunteer farmer trainers, the data shows that VFTs were important sources of information where they were available and in a limited number of other DMGs as well. The VFTs have an added advantage because they use the local language, live in the same local conditions and share the same resources with the farmers, meaning that they are able to understand farmers' needs better than other people. Additionally, the VFTs are trained and known to the farmers and are therefore, to some extent, able to win farmers' trust as reliable information providers.

Disaggregating by household type, results in Table 11 show that a higher proportion of women in male-headed households had access to the MoALFD and private service providers than women-headed households. The VFTs, on the other hand, were the fifth most accessed information source by women-headed households and were ranked $8^{\text {th }}$ by women in maleheaded households. This shows that the VFTs were among the most frequently accessed information sources by women-headed household, perhaps because of their proximity implying that less cost is needed to access them. The ranking of VFTs varied across sites. Implications are that some farmers do not appreciate the VFTs which could be because they feel that fellow farmers might not have enough skills and knowledge to educate them 
compared to other professional extension agents like government extension staff. There was no correlation between the ratio of farmers per VFT and percentage of farmers accessing information from VFTs per site.

Further analysis on access to information sources was done by site. Results show that radio was mostly accessed by farmers in Tanykina, Kapcheno, Metkei, Olkalou and Taragoon, while Kieni farmers had more access to MoALFD. Radio is thus a vital source of information on new technologies for rural farmers. Generally, VFTs were mostly accessed in Kieni, Sot and Kapcheno sites. The VFTs in these sites were probably active in disseminating information. Except in two DFBAs, findings revealed that the ratio of VFTs to farmers in a site influenced the percentage of farmers accessing information from them. Areas with higher percentage of VFTs recorded higher percentages of farmers accessing information from the trainers.

More than $80 \%$ of the farmers accessed information on Napier grass, mineral supplementation and concentrates, depicting that a majority of farmers tend to access information on common feeds. Differentiating by gender, male farmers had more access to information on lucern, desmodium silage making and fodder shrubs compared to female farmers. Male farmers have more access to information on modern technologies than female farmers. This is tied to the fact that a higher percentage of male farmers have access to more information sources (10) than female farmers, thus making them more aware and interested in new technologies. Likewise, an analysis by women household types shows that a higher percentage of women in male-headed households had access to information on Rhodes grass, conservation of crop residues and feed formulation compared to their counterparts in womenheaded households.

With regard to the source of livestock feed information, the study found that farmers' access information on different livestock feed technologies from particular sources. Most farmers received information on mineral supplementation and concentrates from the radio. Radio therefore played a major role in informing farmers on the use of common feeds. Radio is also mostly used to pass information on general knowledge as opposed to specific knowledge. Information on Napier grass, Rhodes grass, conservation of crop residues, silage making and fodder shrubs was accessed through the CESPs, field days and MoALFD. Hence, technologies that required demonstrations were mostly accessed from interpersonal sources (or face to face sources). Such sources provide specific information and are critical in informing farmers on modern technologies.

Further, results show the important technologies disseminated through each source. Radio covered concentrates, mineral supplementation and Napier grass as key technologies. Additionally, Napier grass and silage making were the most important technologies for MoALFD, CESPs and field days. Volunteer farmer trainers, on the other hand, covered Napier grass, Rhodes grass, conservation of crop residues and mineral supplementation as their key technologies. Notably, radio is an importance source of information on traditional 
practices while MoALFD, CESPs and VFTs are important information sources of both traditional and modern technologies.

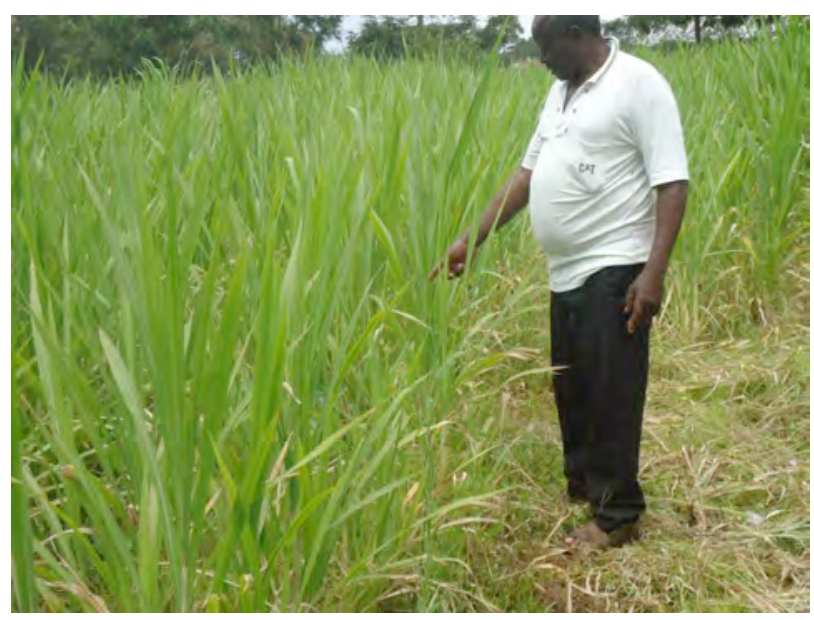

\section{Photo1: A Napier grass demonstration plot in a VFT's plot}

The three most preferred sources of information were listed as CESPs, radio and MoALFD. The use of CESPs reflects the role of community extension officers in providing information to farmers. Being professionals in extension gives the CESPs an upper hand. Radio was ranked second perhaps because it is available in rural areas. It was noted during the survey that CESPs work closely with the MoALFD which explains why the ministry was the third preferred source of information by farmers. These results echo the findings of Ogunremi et al. (2013) who reported that aquaculture farmers in Nigeria preferred radio and extension agent sources.

The VFTs were the sixth preferred source overall. While some sites appreciated the work of VFTs, farmers in Metkei, Taragoon and Tanykina gave a low score to the trainers. These sites had challenges in maintaining their groups and hence VFTs may not have had forums for sharing information. Some farmers did not value information received from fellow farmers and preferred getting information from other experts in agriculture. In addition, there were instances when VFTs were not performing to their potential.

Interestingly, exchange visits and skilled farmers were among sources with low preference. The farmers visited were perhaps at too high a level to provide knowledge and advice that was useful to other farmers. Feder and Savastano (2006) confirm this finding in their study on the role of opinion leaders in diffusing new knowledge among farmers. In this case, farmers learnt best from people just above their level, and not too high.

While both genders had a strong preference for CESPs, the study shows that female farmers had a higher preference for neighbours as sources of information while males preferred MoALFD staff. Female farmers therefore prefer using their social networks to acquire information. The findings coincide with those of Conley and Udry's (2010) on their estimate of the effect of observing neighbours. 
Reliability, frequency of contact, accessibility and affordability of the three most preferred sources were analysed in this study. Further, similar aspects were used to rate how the VFTs fared compared to the three preferred sources. Overall, farmers ranked CESPs, MoALFD and VFTs as more reliable sources than radio. This finding probably reflects farmers' preference for learning by seeing and direct interaction rather than just hearing. Further, results on frequency of use indicate that farmers had more contact with CESPs and VFTs as compared to radio and MoALFD. Additionally, CESPs, radio and VFTs were viewed as more accessible and affordable than MoALFD. The issue of distance to the source of information seems to play a paramount role in enhancing access to information. Unlike CESPs and trained farmers, the government extension staffs operate from their offices which may be far from farmers' homes. Overall, CESPs and VFTs had the highest scores on reliability, frequency, accessibility and affordability and were therefore very effective sources of information dissemination. Differentiating by gender, male farmers appeared to favour CESPs while female farmers found neighbours to be more effective. Earlier results support the finding where male farmers were found to have better access to community extension staff than female farmers who as a result sought information from their neighbours.

With regard to training received, the proportion of men and women DFBA members trained in feed technologies was about the same, $90.1 \%$ for male members and $87.4 \%$ for women. However, it would appear that women received training on fewer technologies than men. The results further indicate that women in female-headed households received much less training than did women in male-headed households. Disaggregating by sites, Napier grass was the most trained technology in all sites. This could be because the grass is adaptable in all agro ecological zones and is a common feed to all farmers. The findings show that institutions still offer trainings on conventional feeds, such as concentrates and mineral supplementation. Such trainings are important for updating farmers' skills. Regarding the training institution, the study reported that farmers receive trainings from a number of institutions namely CESPs, neighbours, MoAFLD, input dealers, self-experience, VFTs, NGO, FTC, KARI and ASK. Generally, all institutions except input dealers offered training on Napier grass particularly on new varieties. Input dealers trained on feeds that they supplied which included mineral supplements, concentrates and Rhodes grass.

After training, farmers take pride in sharing information with their neighbours, either individually or in groups. In this study it was found that more than $70 \%$ of farmers shared information obtained from trainings with other farmers. As noted by Kiptot and Franzel, (2013b) the main motivation for sharing information with others is social capital gains such as personal satisfaction, recognition, gaining confidence, increased social networks, and enhanced social status through fame and popularity. Majority of the farmers shared knowledge on Napier grass, conservation of crop residues, Rhodes grass, mineral supplementation and concentrates. However, $77 \%$ of males shared information while only $66 \%$ of women did so, though the difference was not significant. Males and females also shared the same numbers of practices, about 3.5, with others. 
With regard to the practices on farm, more farmers practised Napier grass, mineral supplementation and concentrates compared to other feed technologies. This shows that farmers still use traditional feed practices. The high usage could also be linked to the availability of the feeds and that farmers have knowledge and skills on these particular feeds. There were few differences between gender groups where more women in male-headed households practised conservation of crop residues than women in female-headed households. Married women have greater access to livestock feed resources than single women.

Discerning by sites, the use of kikuyu grass was common among farmers in the Rift Valley region (Cherang'ani, Tanykina, Kapcheno, Metkei, Taragoon and Sot). Farmers in the central region of Kenya (Kieni) preferred Napier grass and conservation of crop residues. It is evident that farmers with large farm sizes, such as those in Rift Valley, are reluctant to adopt conserved feed as compared to those with small farm sizes.

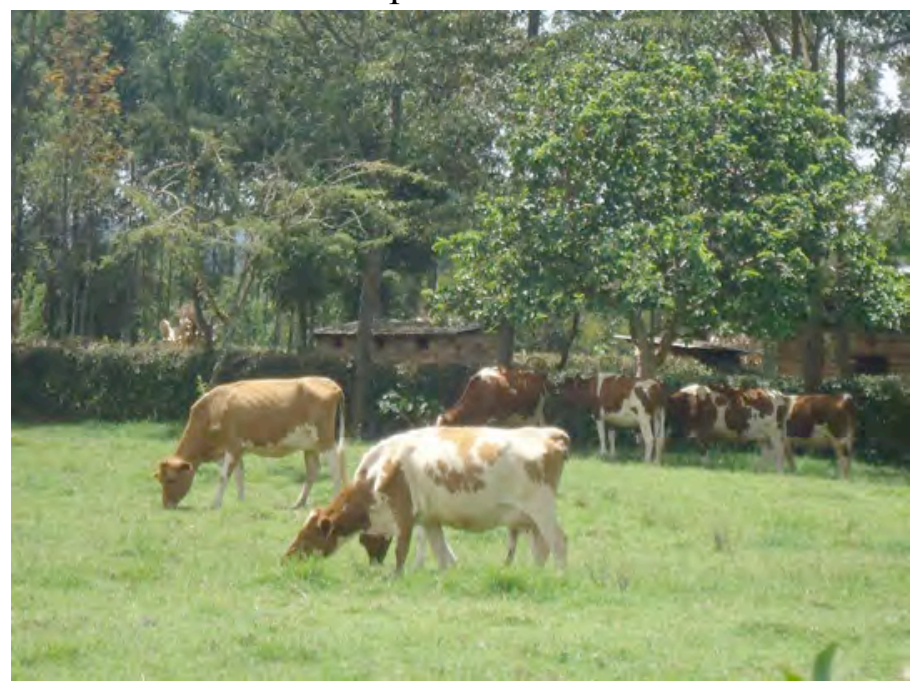

\section{Photo 2: Cows feeding on kikuyu grass under paddocking system in Cherang'ani}

Generally, there was limited use of fodder shrubs and herbaceous legumes (lucerne and desmodium) across the sites. Farmers attributed this to lack of seedlings and planting material, as well as information. During our field work for instance, we spotted desmodium in the farms, along river banks and at the roadside but surprisingly farmers were not aware of the plant. One farmer said "When I cut grass for my cow, I realized the cow eats even this weed (desmodium) but I did not know that it is a very important livestock feed. I will start growing it on my farm". Training institutions definitely need to identify such gaps and offer required training. 

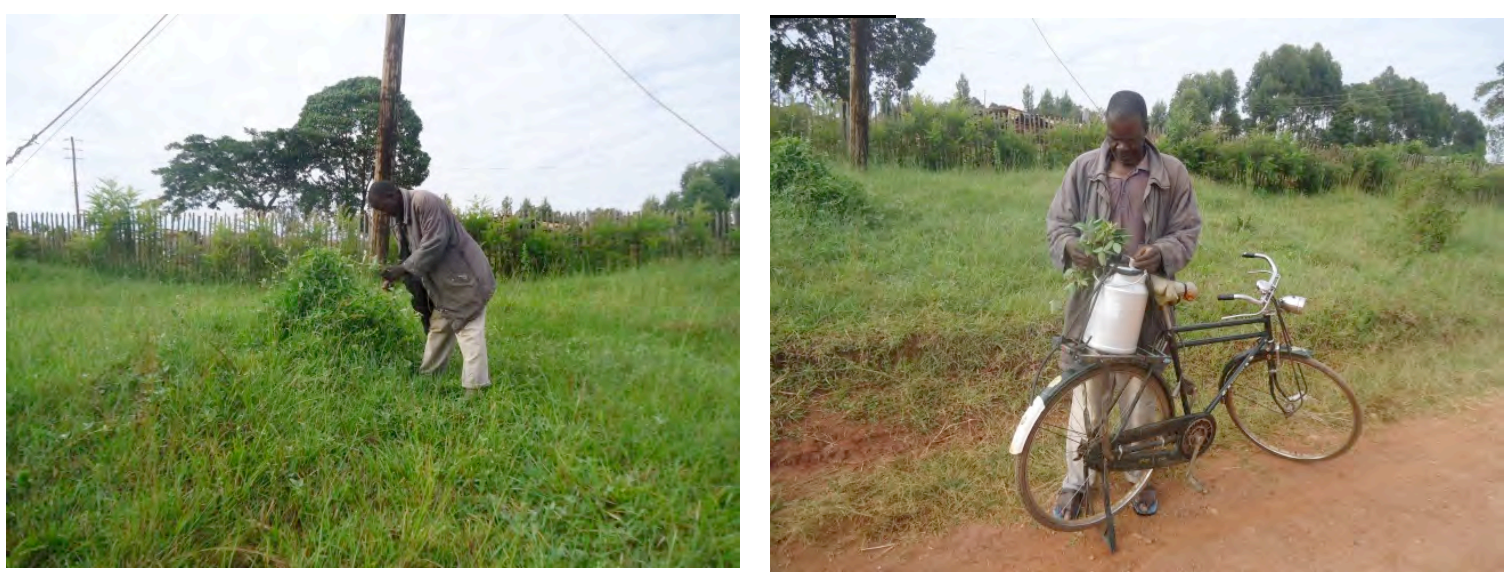

\section{Photo 3: A farmer picks desmodium vines to plant in his farm}

Analysis of preferred livestock feed technologies showed Napier grass as the most preferred feed technology. Kikuyu grass came second, meaning that farmers value natural grass perhaps because it's readily available and comes at no cost. The third preferred technology was conservation of crop residues, implying that farmers are embracing conservation techniques that can boost milk production in dry seasons. There was no gender difference in the preference of technologies practised. However, practices differed across sites. Farmers in Tanykina and Sot preferred kikuyu grass, those in Cherang'ani, Kapcheno, Metkei, Olkalou and Kieni preferred Napier grass, while those in Taragoon preferred conservation of crop residues.

A comparison between technologies trained with those practised and/or shared shows a worrying trend on the adoption of modern feeds. Diffusion of information and adoption of common feeds like Napier grass was high. However, farmers face challenges in adopting other feeds namely Rhodes grass, silage making, hay baling and fodder shrubs among others. This could be due to the cost involved in preparing the feed, and characteristics of the technology, e.g. long wait before harvesting. Other factors such as labour and land requirements might also have contributed to low adoption. Access to planting materials and other resources for making the feeds could also be an issue. "Madam, do you have calliandra seeds? Where can we get them?" This question came up in most interviews. It shows that farmers have inadequate information on where to obtain seeds.

Results on the farmers' level of understanding of livestock feed technologies reveal that farmers have a good grasp of the livestock feeds. The mean score was similar for men and women. Overall, majority of the farmers had better understanding of Napier grass as compared to other feed technologies. This was expected since Napier grass is a common technology that cuts across all sites. Additionally, farmers were found to have accessed more information on Napier grass and were also trained on the same. Silage making was another well understood technology. The study shows that even though there is low usage of silage, farmers have good knowledge on it. The fact that farmers do not use a particular technology does not necessarily mean that they do not understand it. 


\subsection{CONCLUSION AND RECOMMENDATIONS}

This study set out to determine farmers' sources of information, preference and determinants of accessing preferred information sources. It further documents the extent of information sharing by farmers. The findings provide important insights into how information is disseminated among smallholder farmers. It is evident that radio is the single most accessed source of information followed by CESPs and MoALFD, in that order. There is a significant difference in access to information sources between male and female farmers; a higher percentage of male farmers have access to both electronic and interpersonal sources. Future studies should provide insights on the causes of the differences and suggest solutions that would promote equity in access to information between genders.

With regard to the preferred information sources, the study identified CESPs, radio and MoALFD as the first, second and third most popular sources, respectively. Clearly, both impersonal and interpersonal information sources are preferred by farmers in the study area. Volunteer farmer trainers were ranked sixth and scored highly on reliability, frequency of contact, accessibility and affordability. Their role in information dissemination is thus important, especially relative to their cost, which is much lower than other information sources. There is need for agricultural organizations, both government and NGOs, to sensitize farmers on the importance of groups and train more farmers.

Generally, farmers access information on farm practices that are common in their area. In this study Napier grass appeared as the most common practice across sites. Regardless of the source, findings revealed that information on familiar technologies such as Napier grass was the most accessed. Yet, farmers reported to have adequate knowledge of the technologies. The reasons may be because rates of use are still quite low for some (e.g. concentrates) and management of others (e.g. Napier grass) can be improved to increase yields.

The study highlighted the relationship between the type of technology accessed and the source of information. Evidence shows that impersonal sources are useful in accessing information on common and less technical technologies, while the interpersonal sources are useful for newer and more complex technologies. Thus, for successful information dissemination, agricultural extension service providers need to make appropriate choices on the dissemination media based on the technology to be trained.

Viewed from the gender lens, evidence suggests that male farmers and women in maleheaded households have more access to information than female-headed households. This could be attributed to limited education, mobility and productive resources of the female heads of households. Further, findings on information sharing show that men are more active in information sharing than women. The results put across gender disparities in access to information that need to be addressed. Extension agents need to make deliberate efforts to reach farmers in female-headed households. Additionally, policy makers may be required to come up with policies to enhance information dissemination, taking in consideration the differences between genders. 


\subsection{REFERENCES}

Ali, J. and Kumar, S. (2011). Information and Communication Technologies (ICTs) and Farmers Decision-Making across the Agricultural Supply Chain. International Journal of Information Management, 31:149-159.

Anderson, J. R. and Feder, G. (2007). Agricultural extension, in R.E. Evenson \& P. Pingali (eds.), Handbook of Agricultural Economics, Vol. 3, Agricultural Development: Farmers, Farm Production, and Farm Markets, p. 2343-2378, Elsevier, Amsterdam.

Ariyo, C., Ariyo, O., Okelola, E., Aasa, O.S., Awotide, G., Aaron, J. and Oni, O. (2013). Assessment of the Role of Mass Media in the Dissemination of Agricultural Technologies among Farmers in Kaduna North Local Government Area of Kaduna State, Nigeria, Journal of Biology, Agriculture and Healthcare, 3:6.

Babu, C., Glendenning, J., Asenso-Okyere, K. and Govindarajan, K. (2012). Farmers' Information Needs and Search Behaviours: Case study in Tamil Nadu, India. IFPRI Discussion paper.

Bandura, A. (1993). Perceived Self-efficacy in Cognitive Development and Functioning. Educational Psychologist, 28:117-148.

Bareng S.D., Boateng, C.A and Anaglo, J.N. (2014). Preferred Agricultural Information Sources Among Crop Farmers in the Central Tongu District. Journal of Sociology, 2:3

Benin, S., Nkonya, E., Okecho, G., Pender, J., Nahdy, S., Mugarura, S., Kato, E. and Kayobyo, G. (2007). Assessing the Impact of the National Agricultural Advisory Services (NAADS) in the Uganda Rural Livelihoods', IFPRI Discussion Paper 00724. International Food Policy Research Institute (IFPRI), Washington, DC, viewed 27 August 2013, from http://www.ifpri.org/sites/default/files/publications/ifpridp00724.pdf

Benin, S., Nkonya, E., Okecho, G., Randriamamonjy, J., Kato, E., Lubade, G. and Kyotalimye, M. (2011). Returns to Spending on Agricultural Extension: The Case of the National Agricultural Advisory Services (NAADS) Programme of Uganda. Agricultural Economics, 42(2): 249-267.

Birner, R., Davis, K., Pender, J., Nkonya, E., Anandajayasekeram, P., Ekboir, J., Mbabu, A., Spielman, D., Horna, D. and Benin, S. (2006). From Best Practice to Best Fit: a Framework for Analyzing Agricultural Advisory Services Worldwide. DSGD Discussion Paper 37. Washington, DC: Development Strategy and Governance Division, International Food Policy Research Institute.

Cartmell, D., Orr, C. and Kelemen, D. (2004). Methods of Information Dissemination to Limited-Scale Land Owners. Available at: http://agnews.tamu.edu/saas/2004/infodissemination.pdf. 
Cochran, W.G. (1977). Sampling Techniques, Third Edition, New York: John Wiley \& Sons, Inc.

Conley, T.G. \& Udry, C.R. (2010), 'Learning about a New Technology: Pineapple in Ghana', American Economic Review 100(1), 35-69.

Çukur, T. and Saner, G. (2013). Determination of Information Resources of Earthen Pond Fish Farmers in Milas District, Muğla Province, Turkey. Journal of Food, Agriculture and Environment, 11 (1): 754-759.

Davis, K. (2008). Extension in Sub-Saharan Africa: Overview and Assessment of Past and Current Models, and Future Prospects. Journal of International Agricultural Education and Extension, 15 (3): 15-28.

Davis, K., Swanson, B., Amudavi, D., Ayalew Mekonnen, D., Flohrs, A., Riese, J., Lamb, C. and Zerfu, E. (2010). In-Depth Assessment of the Public Agricultural Extension System of Ethiopia and Recommendations for Improvement. IFPRI Discussion Paper 01041. Washington, DC: International Food Policy Research Institute

Djojomartono, M. and Pertini, S. (1998). Present Status of Information Technology Utilization in Indonesian Agriculture. Bogor: The Asian Federation for Information Technology in Agriculture.

Egziabher, K., Mathijs, E., Deckers,J., Gebrehiwot, K., Bauer, H. and Maertens, M. (2013). The Economic Impact of a New Rural Extension Approach in Northern Ethiopia. Bioeconomics Working Paper Series, Working Paper 2013/2.

Farooq, S., Muhammad, S., Chaudhary, K. and Ashraf, I. (2007). Role of Print Media in the Dissemination of Agricultural Information among Farmers. Pakistan Journal of Agricultural Sciences, 44(2): 378-380.

Feder, G. and Savastano. S. (2006). The Role of Opinion Leaders in the Diffusion of New Knowledge: The Case of Integrated Pest Management. World Development, 34 (7): 12871300 .

Kiptot, E. and Franzel, S. (2013). Effectiveness of the Volunteer Farmer Trainer Approach in Dissemination of Livestock Feed Technologies: A Survey of Farmer Trainees in Kenya. Draft Research Report, World Agroforestry Centre.

Kiptot, E., Lukuyu, B., Franzel, S. and Place, F. (2011). The Farmer Trainers Approach in Technology Dissemination in Kenya: Farmer Trainers and Trainees Perspectives. Working Paper.

Kirui, J. and Franzel, S. (2012). East Africa Dairy Development Project Semi-Annual Report (January-June 2012). World Agroforestry Centre. Project Report. 
Kolb, D. (1984). Experiential Learning: Experience as the Source of Learning and Development. New Jersey, Prentice-Hall.

Leeuwis, C. (2003). Communication for Rural Innovation: Rethinking Agricultural Extension. Blackwell Publishing, UK.

Lukuyu, B., Place, F., Franzel, S. and Kiptot, E. (2012) Disseminating Improved Practices: Are Volunteer Farmer Trainers Effective? The Journal of Agricultural Education and Extension, 18:5, 525-540, DOI: 10.1080/1389224X.2012.707066.

Matata, Z., Masolwa, L., Ruvuga, S. and Bagarama, M. (2013). Dissemination Pathways for Scaling-up Agroforestry Technologies in Western Tanzania. Journal of Agricultural Extension and Rural Development, 5(2): 31-36.

Mati, B. (2012). System of Rice Intensification (SRI): Growing More with Less Water. Latest Update on SRI in Kenya. SRI Farmers Now Turned into Trainers in Kenya!

Meitei, L.S. and Devi, T.P. (2009). Farmers Information Needs in Rural Manipur: An Assessment. Annals of Library \& Information Studies, 56 (1): 35-40.

Meitei, S. and Devi, T. (2009). Farmers Information Needs in Rural Manipur: An Assessment. Annals of Library and Information Studies, 56:35-40.

Muhammad, S., 2005. Agricultural Extension: Strategies and Skills. Unitech Communications, Faisalabad, Pakistan.

Munyua, H., 2000. Application of Information Communication Technologies in the Agricultural Sector in Africa: A Gender Perspective. In: Rathgeber, E. \& Adera, E.O. (eds.) Gender and Information Revolution in Africa IDRC/ECA, 85-123.

Mzungu, T. (2013). Review of 2012 Media Consumption in Kenya, How are Audiences Engaging with the Traditional Media Platforms? Retrieved on $20^{\text {th }}$ March, 2014, Available www.ipsos.co.ke.

Okitoi, L., Ondwasy, H., Obali, M. and Murekefu, F. (2007). Gender Issues in Poultry Production in Rural Households of Western Kenya. Livestock Research for Rural Development, 19 (2) 2007.

Oladeji, J., Oyesola O., Ogunleye K. and Raji, K. (2011). Agricultural Information Needs of Root and Tuber Farmers in the Atisbo Local Government Area of Oyo State, Nigeria. Journal of Agriculture and Food Information, 12 (2): 199-205.

Oriakhi, H. and Okoedo-okojie, D. (2013). Arable Crop Farmers Preference for Agricultural Information Sources and Adoption of Technology in Edo State, Nigeria. IOSR Journal of Agriculture and Veterinary Science, 3 (1): 31-35. 
Ozawa, V.N. (1995). Information Needs of Small Scale Farmers in Africa: The Nigerian Example. Quarterly Bulletin of the International Association of Agricultural Information Specialists, IAALD/CABI, University of Agriculture Makurdi, Nigeria, 40, 1. http://www.worldbank.org/html/cgiar/newsletter/june97/9nigeria.html

Rehman, F., Muhammad, S., Ashraf, I., Mahmood, K., Ruby, T. and Bibi, I. (2013). Effect of Farmers' Socio-Economic Characteristics on Access to Agricultural Information: Empirical Evidence from Pakistan. The Journal of Animal and Plant Sciences, 23(1): 324-329. ISSN: 1018-7081.

Rivera, M., Qamar, K. and Crowder, L. (2001). Agricultural and Rural Extension Worldwide: Options for Institutional Reform in Developing Countries. Rome: Food and Agriculture Organization of the United Nations (FAO).

Shrestha, S. (2013). Decentralizing the Farmer-to-Farmer Extension Approach to the Local Level. Paper Submitted to CAPSA for the "Technology Transfer for Smallholder Farmers" Policy Dialogue.

Ssemankula and Mutimba (2011). Effectiveness of the Farmer-to-Farmer Extension Model in Increasing Technology Uptake in Masaka and Tororo Districts of Uganda. South African Journal of Agricultural Extension, 39: 2, 2011: 30-46.

Sulaiman, R.V., and Davis K.D. (2012). The "New Extensionist": Roles, Strategies, and Capacities to Strengthen Extension and Advisory Services. Global Forum for Rural Advisory Services (GFRAS), Lindau, Switzerland.

Swanson, B. and Rajalahti, R. (2010). Strengthening Agricultural Extension and Advisory Systems: Procedures for Assessing, Transforming, and Evaluating Extension Systems. Agriculture and Rural Development, Discussion Paper 45.

Swanson, B.E. (2008). Global Review of Good Agricultural Extension and Advisory Service Practices, Food and Agriculture Organization of the United Nations, Rome.

Wellard, K., Rafanomezana, J., Nyirenda, M., Okotel, M. and Subbey, V. (2013). A Review of Community Extension Approaches to Innovation for Improved Livelihoods in Ghana, Uganda and Malawi, The Journal of Agricultural Education and Extension, 19:1, 21-35. 


\section{WORKING PAPER SERIES}

2013

171. Stakeholder Preferences over Rewards for Ecosystem Services: Implications for a REDD+ Benefit Distribution System in Viet Nam

172. Payments for ecosystem services schemes: project-level insights on benefits for ecosystems and the rural poor

173. Good practices for smallholder teak plantations: keys to success

174. Market analysis of selected agroforestry products in the Vision for Change Project intervention Zone, Côte d'Ivoire

175. Rattan futures in Katingan: why do smallholders abandon or keep their gardens in Indonesia's 'rattan district'?

176. Management along a gradient: the case of Southeast Sulawesi's cacao production landscapes

2014

177. Are trees buffering ecosystems and livelihoods in agricultural landscapes of the Lower Mekong Basin? Consequences of climate-change adaptation. http://dx.doi.org/10.5716/WP14047.PDF

178. Agroforestry, livestock, fodder production and climate change adaptation and mitigation in East Africa: issues and options. http://dx.doi.org/10.5716/WP14050.PDF

179. Trees on farms: an update and reanalysis of agroforestry's global extent and socio-ecological characteristics. http://dx.doi.org/10.5716/WP14064.PDF

180. Beyond reforestation: an assessment of Vietnam's REDD+ readiness. http://dx.doi.org/10.5716/WP14097.PDF

181. Farmer-to-farmer extension in Kenya: the perspectives of organizations using the approach. http://dx.doi.org/10.5716/WP14380.PDF

182. Farmer-to-farmer extension in Cameroon: a survey of extension organizations. http://dx.doi.org/10.5716/WP14383.PDF

183. Farmer-to-farmer extension approach in Malawi: a survey of organizations: a survey of organizations http://dx.doi.org/10.5716/WP14391.PDF

184. Seri Agroforestri dan Kehutanan di Sulawesi: Kuantifikasi jasa lingkungan air dan karbon pola agroforestri pada hutan rakyat di wilayah sungai Jeneberang http://dx.doi.org/10.5716/WP14391.PDF

185. Options for Climate-Smart Agriculture at Kaptumo site in Kenya http://dx.doi.org/10.5716/WP14394.PDF

186. Agroforestry for landscape restoration and livelihood development in Central Asia http://dx.doi.org/10.5716/WP14143.PDF

187. Projected climate change and impact on bioclimatic conditions in the Central and South-Central Asia Region" http://dx.doi.org/10.5716/WP14144.PDF

188. Land cover changes, forest loss and degradation in Kutai Barat, Indonesia http://dx.doi.org/10.5716/WP14145.PDF

189. The farmer-to-farmer extension approach in Malawi: a survey of lead farmers. http://dx.doi.org/10.5716/WP14152.PDF

2015

190. Evaluating indicators of land degradation and targeting agroforestry interventions in smallholder farming systems in Ethiopia. http://dx.doi.org/10.5716/WP14252.PDF

191. Land health surveillance for identifying land constraints and targeting land management options in smallholder farming systems in Western Cameroon. http://dx.doi.org/10.5716/WP14253.PDF

192. Land health surveillance in four agroecologies in Malawi

193. Cocoa land health surveillance: an evidence-based approach to sustainable management of cocoa landscapes in the Nawa region, South-West Côte d'Ivoire

194. Situational analysis report: Xishuangbanna autonomous Dai Prefecture, Yunnan Province China. http://dx.doi.org/10.5716/WP14255.PDF

195.Farmer-to-farmer extension: a survey of lead farmers in Cameroon. http://dx.doi.org/10.5716/WP15009.PDF

196. From transition fuel to viable energy source Improving sustainability in the sub-Saharan charcoal sector http://dx.doi.org/10.5716/WP15011.PDF

197. Mobilizing Hybrid Knowledge for More Effective Water Governance in the Asian Highlands http://dx.doi.org/10.5716/WP15012.PDF

198. Water Governance in the Asian Highlands http://dx.doi.org/10.5716/WP15013.PDF 
The World Agroforestry Centre is an autonomous, non-profit research organization whose vision is a rural transformation in the developing world as smallholder households increase their use of trees in agricultural landscapes to improve food security, nutrition, income, health, shelter, social cohesion, energy resources and environmental sustainability. The Centre generates science-based knowledge about the diverse roles that trees play in agricultural landscapes, and uses its research to advance policies and practices, and their implementation that benefit the poor and the environment. It aims to ensure that all this is achieved by enhancing the quality of its science work, increasing operational efficiency, building and maintaining strong partnerships, accelerating the use and impact of its research, and promoting greater cohesion, interdependence and alignment within the organization.

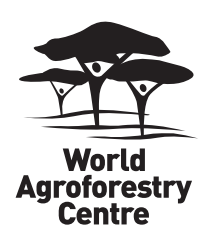

United Nations Avenue, Gigiri • PO Box 30677 • Nairobi, 00100 • Kenya Telephone: +254207224000 or via USA +1 6508336645 Fax: +254207224001 or via USA +1 6508336646 Email: worldagroforestry@cgiar.org •www.worldagroforestry.org 